UNITED STATES DEPARTMENT OF THE INTERIOR

Ray Lyman Wilbur, Secretary

GEOLOGICAL SURVEY

W. C. Mendenhall, Director

\title{
Bulletin 829
}

\section{GEOLOGY AND COAL, OIL, AND GAS RESOURCES OF THE NEW KENSINGTON QUADRANGLE PENISYLVANIA}

\author{
BY \\ G. B. RICHARDSON
}

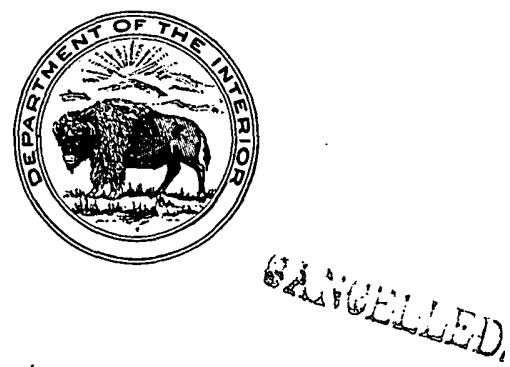

UNITED STATES

GOVERNMENT PRINTING OFFICE

WASHINGTON : 1932 



\section{CONTENTS}

Abstract.

Introduction

General topographic and geologic relations. .

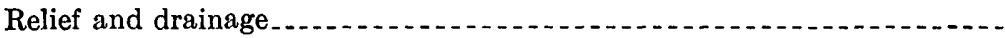

Settlement. ......

Descriptive geology

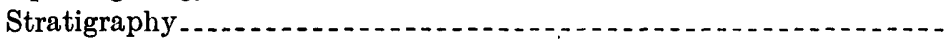

General character and age of the rocks

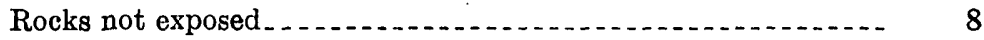

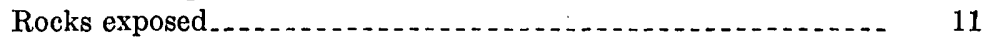

Carboniferous system

Pennsylvanian series.......................... 11

Allegheny formation

Conemaugh formation

Thickness and subdivisions

Distribution and character.................. 16

Relations of the Allegheny and Conemaugh formations......................... 16

Mahoning sandstone member............. 16

Brush Creek limestone member............ 17

Buffalo sandstone member ................. 19

Cambridge ("Pine Creek") limestone member_ 19

Bakerstown coal........................... 21

Saltsburg sandstone member................ 21

"Pittsburgh Reds"

Harlem coal............................ 21

Ames limestone member . . . . . . . . . . . . 21

Duquesne coal.......................... 23

Birmingham shale member................ . 23

Morgantown sandstone member and overlying rocks................................. 23

Monongahela formation.................. 23

Quaternary system....................... 25

Pleistocene and Recent series.................. 25

General features.................... 25

Illinoian glacial deposits

Wisconsin glacial deposits .................. 27

Alluvium_................................... 28

Structure

Surface and near-surface rocks......................... 28

General features.................... 28

McMurray syncline......... 29

Amity anticline $\ldots . . . \ldots \ldots$

Kellersburg anticline............................... 29

Bradys Bend syncline

Faults near Bakerstown station ...................... $\quad 30$

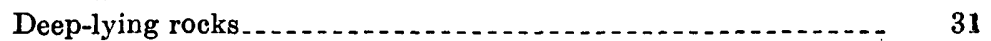


Coal

Historical sketch.....

Upper Freeport coal . . .

Bakerstown coal ......

Pittsburgh coal ....................

Coal below the Upper Freeport . .

Chemical character and use . .

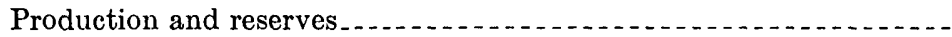

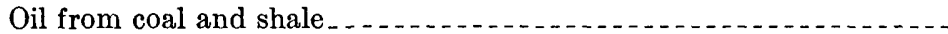

Oil and gas .........

Review of the northern Appalachian region .........................

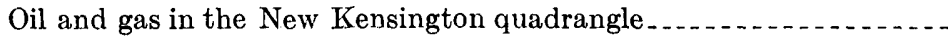

General features. . .

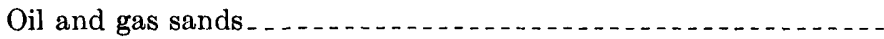

Oil from brine wells at Tarentum . . . .

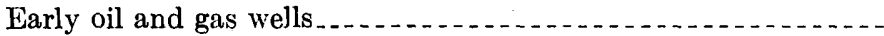

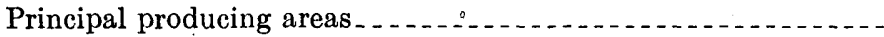

Saxonburg-Lardintown

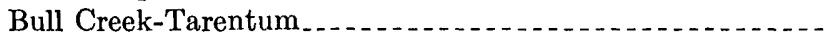

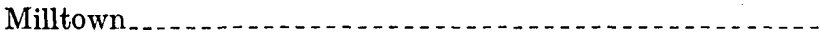

Bakerstown . . . . .

Wildwood

Evergreen .......

Dorseyville......

Glenshaw . . . .

Millerstown ................

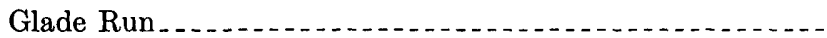

Composition of the natural gas........

Character of the petroleum. .......

Outlook for oil and gas . .

Appendix $\quad$ Records of deep wells in areas adjacent to the New Kensington quadrangle

Generalized sections of rocks in marginal areas of the Pittsburgh-

Huntington Basin.

Measurements of Upper Freeport coal and associated beds

Sections of Hundred-foot and Thirty-foot sands, Dorseyville field....

Records of wells in the New Kensington quadrangle ............. Index

\section{ILLUSTRATIONS}

Plate 1. Geologic map of the New Kensington quadrangle

2. Map showing structure and economic geology of the New Ken- bow sington quadrangle.

3. Contour map showing generalized geologic structure of part of $x_{0} y$ the Pittsburgh-Huntington Basin .............................

4. Generalized columnar section of the rocks exposed in the New Kensington quadrangle 
Plate 5. Sections of diamond-drill holes in the New Kensington quadrangle

6. Thick Upper Freeport coal in a mine. in the New Kensington

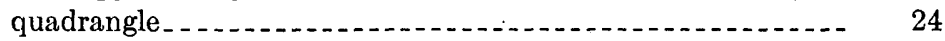

7. Structure contour map of southwestern Pennsylvania _....... 24

8. Sections of oil and gas wells in the New Kensington quadrangle.

9. Sketch map of part of northern Appalachian oil and gas region_-_ . 48

Figure 1. Index map of western Pennsylvania and eastern Ohio . . . . 2

2. Physiographic provinces of part of the northeastern United

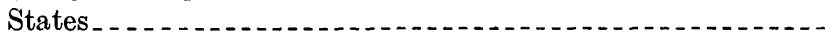

3. Geologic sketch map of part of the northern Appalachian Plateaus and adjacent provinces.

4. Map showing approximate area underlain by the thick Upper Freeport coal. . . . .

5. Map of northern Appalachian bituminous coal region........

6. Sections of Upper Freeport coal in the New Kensington quadrangle

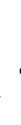

INSERT 



\section{ABSTRACT}

This report is one of a series of publications by the United States Geological Survey on the Appalachian coal, oil, and gas fields. The area described occupies 227 square miles in Allegheny, Butler, and Westmoreland Counties, in western Pennsylvania, immediately north of Pittsburgh.

The outcropping rocks consist of 700 feet of beds of Pennsylvanian age, which include the upper part of the Allegheny formation, the overlying Conemaugh formation, and a few feet of the Monongahela formation. The area is situated in the north-central part of a synclinorium-the Pittsburgh-Huntington Basinwhose axis passes through the New Kensington quadrangle. The strata are gently folded, the steepest dips being less than 200 feet to a mile, and over considerable areas the dip is less than 20 feet to a mile. Structure contours show the deformation of the rocks.

The principal coal bed is the Upper Freeport, at the top of the Allegheny formation, which varies considerably in thickness. Locally it is about 10 feet thick, and it averages more than 7 feet in a large area where it is known as the thick Upper Freeport bed. In places, however, this coal is absent. Coal has been commercially mined in this area since 1830, and intensive development dates from about 1900. During the last year of the World War the coal mines of this quadrangle produced more than $4,000,000$ tons. It is estimated that $800,000,000$ tons of the Upper Freeport coal remains unmined in this area.

The New Kensington quadrangle lies in the east-central part of the northern Appalachian oil and gas region and was actively drilled between 1875 and 1900, when the main producing areas were discovered and the maximum output obtained. For many years the yield of oil and gas has been very little, the average daily output of oil per well being only a fraction of a barrel, but from time to time small productive areas that were missed in previous drilling are discovered. This stimulates the sporadic drilling that goes on year after year.

Oil and gas are obtained from a group of lenticular beds of sand, interstratified with shale, of lower Carboniferous and Upper Devonian age. These sands lie between 1,200 and 2,600 feet below the Üper Freeport coal, but most of the output comes from beds that occupy an interval of 500 to 600 feet in the upper part of the productive zone.

The individual beds are variable, and none of the sands maintain a uniform thickness over a large area, the beds thickening and thinning and locally merging with shale. The sandstones attain a maximum thickness of about 100 feet and the pay streaks of 20 feet, but from 3 to 5 feet is common. Water occurs in the upper sands down to about 1,600 feet below the Upper Freeport coal, below which the sands in general yield little or no water.

The production of oil and gas is characteristically spotted, and good wells adjacent to poor wells or dry holes are common. Oil and gas occur in the more porous parts of the beds, and some of the most productive areas occur along the feather edge of lenses of sandstone.

Notwithstanding the importance of lithology in determining the location of productive areas, in this as in other regions there is a pronounced relation between the occurrence of oil and gas and the structure of the rocks. Gas is commonly 
f ound on the crests of anticlines or on structurally high parts of lenticular sands. Water occupies the structurally low parts of the beds, and oil occurs in an intermediate position between the gas and water if all three are present. Where water is absent oil may be found on the lower flanks of folds or along the axes of synclines.

The sands down to and including the Fifth have been rather thoroughly tested, and it may be expected that future production from these upper sands by the methods now in use will continue to show the decline that has been in progress for many years. In the future as in the past, however, because of the spotted occurrence of oil and gas in lenticular sands of variable porosity, there may be occasionally discoveries of small productive areas in the upper sands. A greater increase in the rate of production that may be obtained from the depleted upper sands is likely to result from improved methods of recovery, which are proving effective in other fields.

The sands below the Fifth that are productive in other areas constitute a potential reserve The Speechley sand, lying 800 to 900 feet below the Fifth and 2,500 to 2,600 feet below the Upper Freeport coal, and the so-called Bradford sand, about 600 feet deeper, are being tested. The deeper-lying sands that yield oil or gas at one place or another in the Appalachian region are also possible sources of production in this area. The Oriskany is estimated to lie about 6,000 feet below the Upper Freeport coal, the Tuscarora some 2,000 feet deeper, and the Trenton limestone probably lies between 10,000 and 11,000 feet below the Upper Freeport coal in the New Kensington quadrangle. 


\title{
GEOLOGY AND COAL, OIL, AND GAS RESOURCES OF THE NEW KENSINGTON QUADRANGLE, PENNSYLVANIA
}

\author{
By G. B. Richardson
}

\section{INTRODUCTION}

The New Kensington quadrangle, bounded by parallels $40^{\circ} 30^{\prime}$ and $40^{\circ} 45^{\prime}$ and meridians $79^{\circ} 45^{\prime}$ and $80^{\circ}$, includes an area of 227 square miles in Allegheny, Butler, and Westmoreland Counties, in western Pennsylvania. (See fig. 1.) This area lies immediately north of the city of Pittsburgh, and the coal, oil, and gas resources of the quadrangle have been actively developed for many years.

This bulletin is one of a series of publications by the United States Geological Survey on the Appalachian coal, oil, and gas fields contained in 15-minute quadrangles-areas embracing a quarter of a "square degree" of the earth's surface-of which topographic maps on a scale of about a mile to the inch $(1: 62,500)$, with a contour interval of 20 feet, are available.

Field work on which the present report is based was begun in 1917, but its completion was delayed by the assignment of the writer to other duties. Efficient assistance was rendered in the field by W. A. Copeland, L. A. Faustino, and L. C. Fenstermacher and both in the field and office by K. K. Kimball. Mr. Kimball is responsible for the accurate determination of many hundred altitudes of key horizons and of oil and gas wells used as a basis in determining structure. The officials of practically all the coal, oil, and gas companies operating in the quadrangle courteously cooperated by furnishing mine maps, records of diamond-drill holes sunk in prospecting for coal, and records of oil and gas wells. Most of the records of diamond-drill holes, however, were furnished with the understanding: that the locations should not be published. The cost of part of the field work was paid by the Topographic and Geologic Survey of Pennsylvania.

The New Kensington quadrangle is part of a large area that was described in two reports of the Second Geological Survey of Pennsylvania more than 50 years ago-Report $Q$, on the Beaver River district, by I. C. White, published in 1878 , and Report $\mathrm{K}^{2}$, on the Fayette and Westmoreland district, by J. J. Stevenson, published in 1877 . 


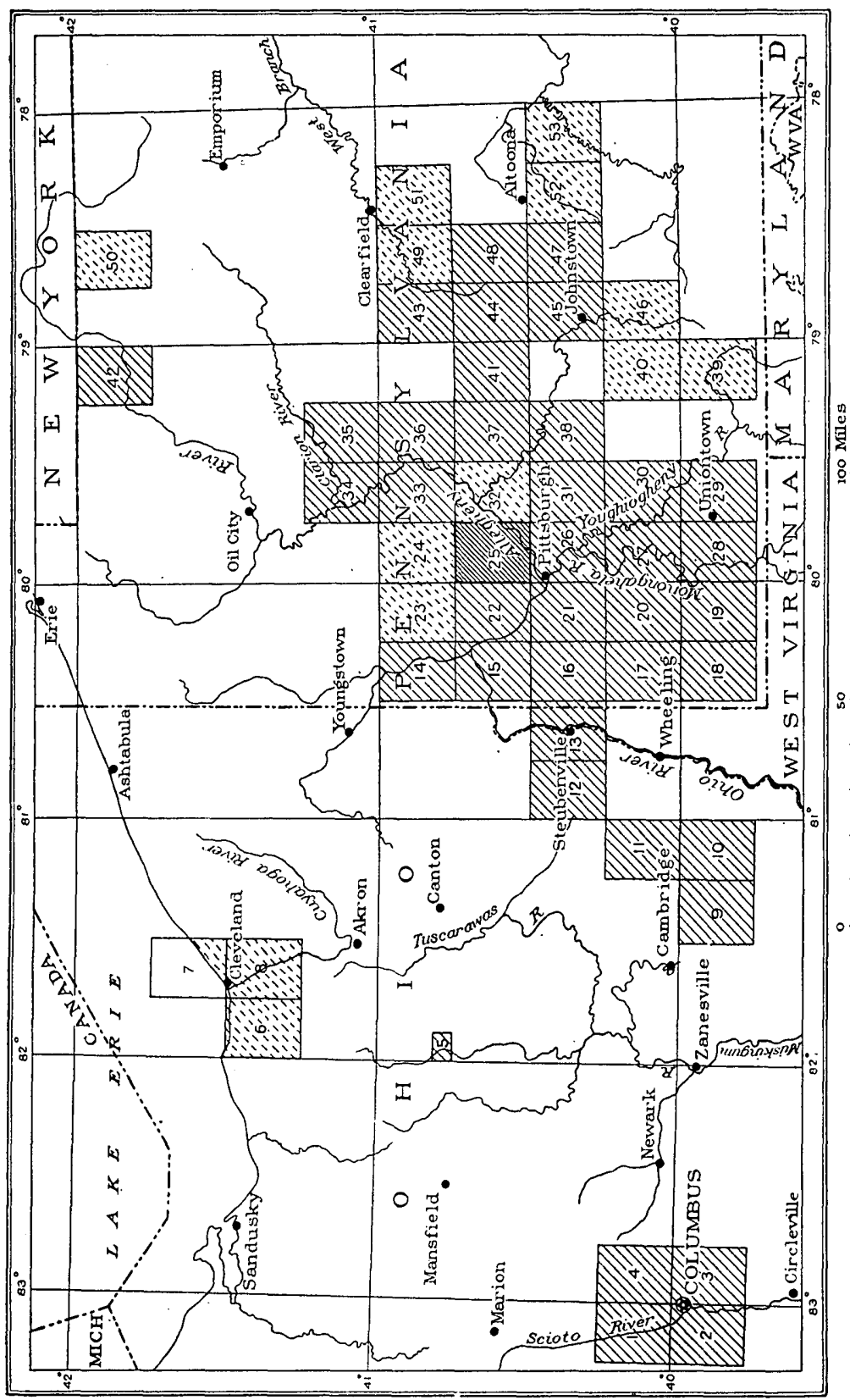

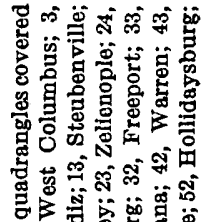

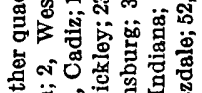

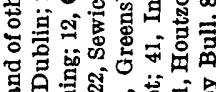

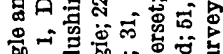

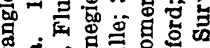

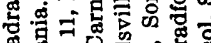

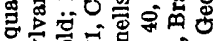
有要

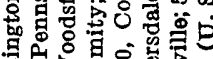

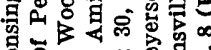
क्ष e

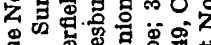
을

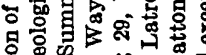
कृ 讨论 of 局 to 更

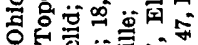

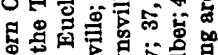

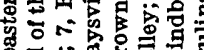

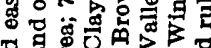

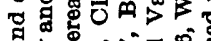
ต of 0 .

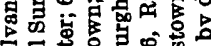

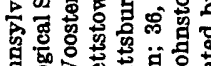

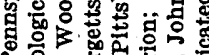

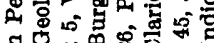

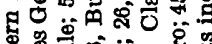

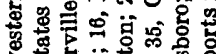

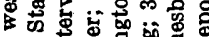

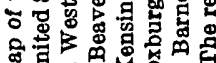

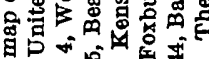

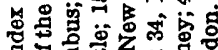
定自

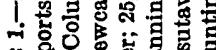

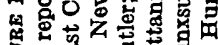

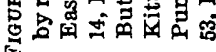


Though the authors of these excellent reports were handicapped by the lack of adequate base maps the many detailed stratigraphic sections that they give were of much assistance in the course of the recent survey.

\section{GENERAL TOPOGRAPHIC AND GEOLOGIC RELATIONS}

In its topographic and geologic relations this quadrangle forms a part of the Appalachian Highlands, which extend from the Atlantic Coastal Plain to the Central Lowland and from Alabama northeastward into Canada. (See fig. 2.) In Pennsylvania, Maryland, and West Virginia the Appalachian Highlands are divided into two almost equal parts by an escarpment, the Allegheny Front. East of this escarpment lies the Valley and Ridge province, long known as the

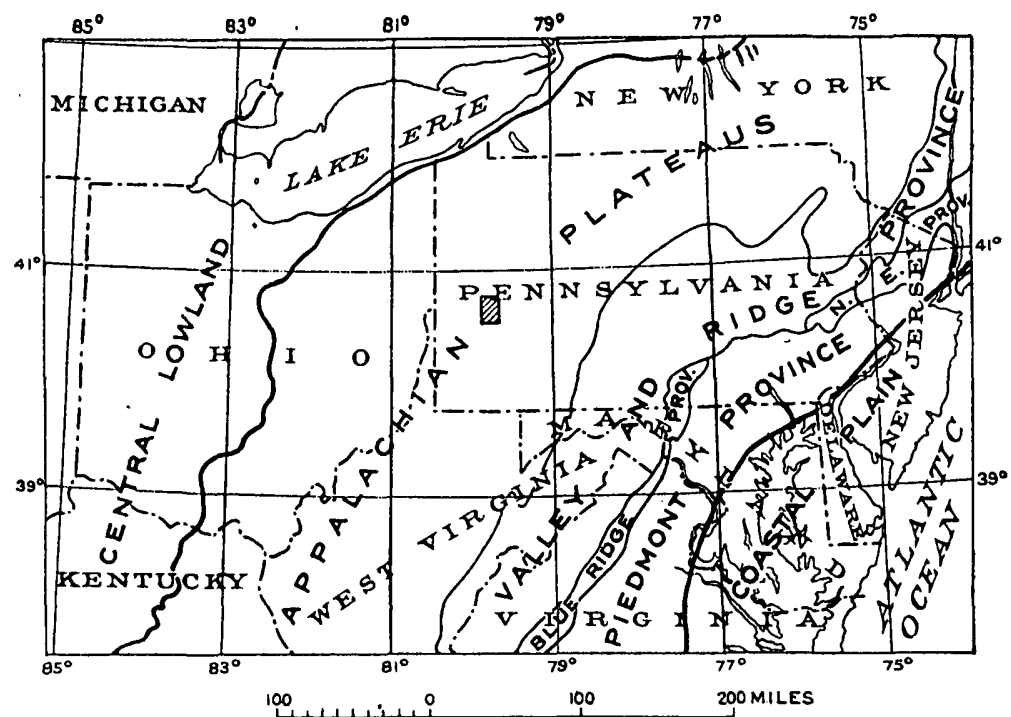

FIGURE 2.-Physiographic provinces of part of the northeastern United States. The New Kensington quadrangle is indicated by shading

Appalachian Valley, which is underlain by sharply folded early Paleozoic strata. Farther east is the Blue Ridge province, the most rugged part of the highlands, bounded on the east by the Blue Ridge. East of the Blue Ridge lies a dissected upland, with some lowlands, the Piedmont province, which forms the easternmost division of the highlands and is underlain largely by pre-Cambrian rocks. West of the Allegheny Front are the Appalachian Plateaus, forming a broad highland belt that is underlain by gently folded Carboniferous and older strata. The New Kensington quadrangle is situated in the Appalachian Plateaus along the axis of the Pittsburgh-Huntington Basin.

The Pittsburgh-Huntington Basin is the broad spoon-shaped synclinorium that lies between the axis of the Cincinnati anticline and 
the Allegheny Front and extends from New York to Kentucky. It includes and in large part is coextensive with the northern Appalachian coal field. The areal distribution of the rocks (see fig. 3) shows the spoon-shaped structure of the basin. Its central part, in southeastern Ohio, southwestern Pennsylvania, and northwestern West Virginia, is floored with beds of Permian age, which are sur-

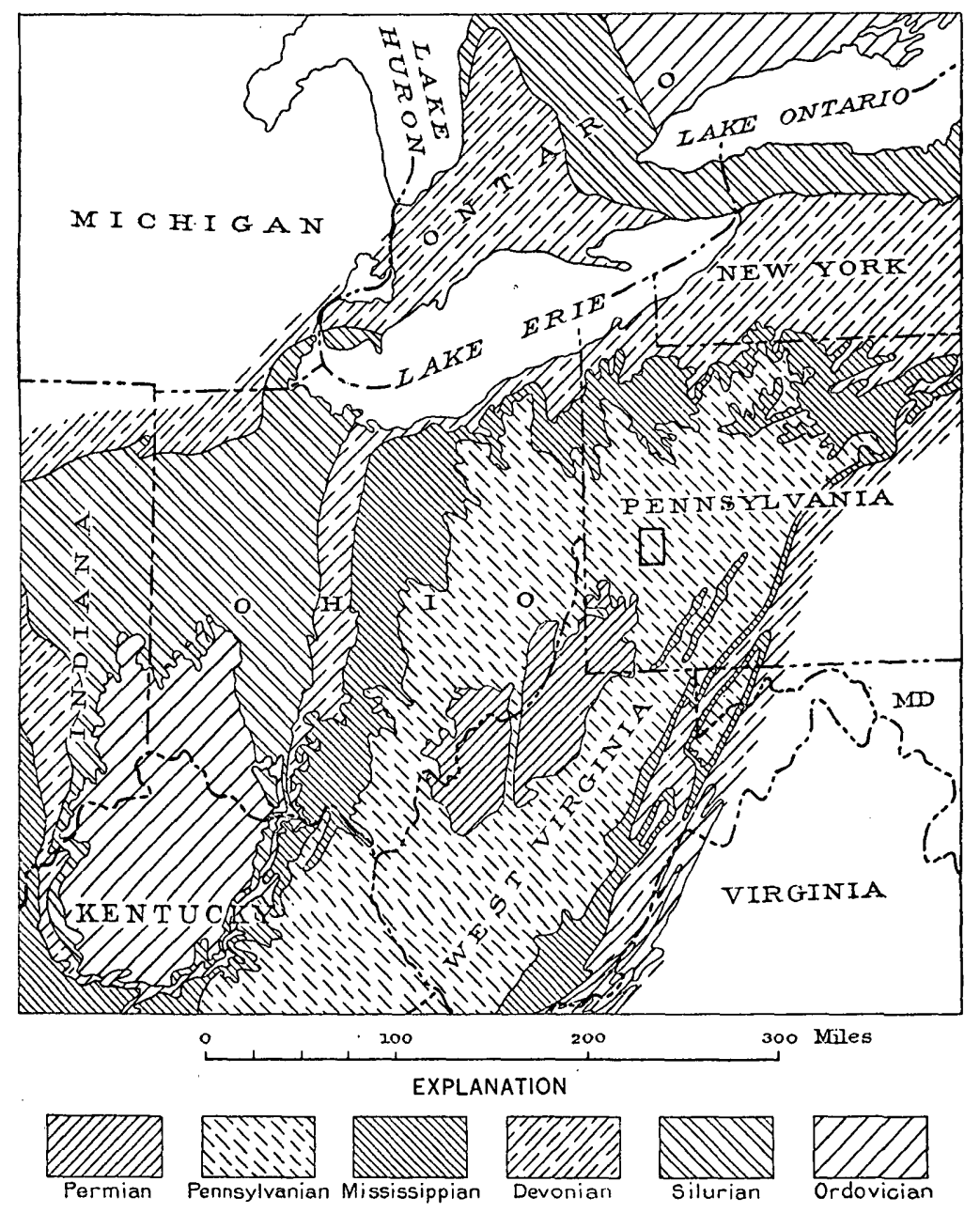

Figure 3.-Geologic sketch map of part of the northern Appalachian Plateaus and adjacent provinces. The rectangular outline in western Pennsylvania indicates the New Kensington quadrangle

rounded by outcrops of Pennsylvanian strata, and along its western, northern, and eastern margins Mississippian, Devonian, Silurian, and older rocks crop out in sequence.

The general structure of the rocks at and near the surface of the basin is shown by 500 -foot cont Jurs in Plate 3.

The central axis through the lowest part of the basin extends in a general southwesterly direction through Pittsburgh and a point about 
10 miles south of Huntington, W. Va. This axis is interrupted by a cross fold, the Burning Springs anticline, which trends north. Southwest of the Burning Springs anticline the axis of the basin is marked by the Parkersburg syncline, the lowest part of which is about 15 miles south of Marietta, Ohio. Northeast of the Burning Springs anticline the axis of the basin is marked by the Middlebourne-Nineveh syncline, the lowest part of which is near the southwest corner of Pennsylvania.

From the low places on the central axis the strata rise in all directions. Along the axis of the basin, northeastward and southwestward, they rise at rates ranging from 15 to 20 feet to the mile. Northwestward from the synclinal axis the strata rise toward the crest of the Cincinnati anticline, a distance of about 160 miles, at rates ranging from 20 to 60 feet to the mile. Southeastward they rise toward the Allegheny Front, a distance of about 80 miles, at an average rate between 50 and 100 feet to the mile. The southeast flank of the basin is complicated by secondary folds, which are more numerous and pronounced at the north, in Pennsylvania, Maryland, and northern West Virginia, than farther south. In a large part of southern West Virginia, west of the margin of the plateaus, the general structure of the southeast flank of the basin is monoclinal, unrelieved by the pronounced secondary folding that is common farther north. The New Kensington quadrangle is situated along the central axis of the basin.

\section{REIJEF AND DRAINAGE}

The New Kensington quadrangle is a hilly country of moderate relief. The lowest part of the area, in the valley of the Allegheny River, is 740 feet above sea level, and the highest part, near the northern border, is 1,400 feet-above sea level. Between the hilltops and the adjacent valleys the difference in altitude is commonly 200 to 500 feet, but in places along the Allegheny River cliffs rise 500 to 600 feet above the valley.. In general the hills, which are composed chiefly of shale, are rounded and of gentle slope, but locally, where there are capping ledges of massive sandstone, the slopes are steep.

Many of the hilltops have a fairly accordant height, which is pl ainly evident when they are viewed from a high point. In the southern part of the quadrangle the hills have altitudes between 1,200 and 1,300 feet; in the northern part, between 1,300 and 1,400 feet. This general accordance in height of the hilltops and the northward increase in altitude is a general feature of the topography of western Pennsylvania. The hilltops are believed to mark a former almost level plain which was uplifted and dissected until only remnants of the former surface are now preserved. ${ }^{1}$

1 Campbell, M. R., Geographic development of northern Pennsylvania and southern New York: Creol. Soc. America Bull., vol. 14, pp. 277-293, 1903. 
The Allegheny River crosses the southeastern part of the New Kensington quadrangle. It occupies a narrow valley which is characterized by the development of terraces that mark stages in the history of Pleistocene glaciation. This quadrangle was not covered by the ice sheet, the southernmost limit of which crossed northwestern Pennsylvania, but the Allegheny River carried a large burden of detritus derived from the melting ice.

The major drainage of the quadrangle is directly tributary to the Allegheny River, chiefly by Bull, Deer, Pine, Pucketa, and Plum Creeks. The northwestern part of the quadrangle drains by way of Glade Run into Connoquenessing Creek, which flows into the Beaver River, a tributary of the Ohio.

\section{SETTLEMENT}

The quadrangle is rather thickly settled. Thriving towns are located in the main valleys and prosperous farms cover the uplands. Practically the entire valley of the Allegheny. River within the quadrangle is built up, the largest towns being Tarentum, New Kensington, Springdale, Oakmont, and Verona. In the valley of Pine Creek and its tributaries are the towns of Etna, Undercliff, and Glenshaw, and smaller settlements are scattered throughout the quadrangle. The Buffalo and Allegheny and the Western Pennsylvania divisions of the Pennsylvania Railroad, the Pittsburgh and Chicago line of the Baltimore \& Ohio Railroad, and the Bessemer \& Lake Erie Railroad cross the quadrangle, and there are a number of interurban trolley lines. The principal occupations outside of the towns are agriculture, coal mining, and the production of oil and gas.

\section{DESCRIPTIVE GEOLOGY}

\section{STRATIGRAPHY}

\section{GENERAL CHARACTER AND AGE OF THE ROCKS}

The New Kensington quadrangle is underlain by sedimentary rocks of Paleozoic age, consisting of shale, sandstone, limestone, clay, and coal. In the valleys of the larger streams there is a thin veneer of Recent alluvium, and terraces along the Allegheny River are formed by deposits of gravel of glacial origin.

The outcropping bedrocks comprise about 700 feet of strata of Pennsylvanian age, which include the upper part of the Allegheny formation, the overlying Conemaugh formation, and a few feet of the Monongahela formation. (See pl. 4.)

The rocks that lie beneath the outcropping beds are known as a result of drilling. Records of diamond-drill holes put down in prospecting for coal show the character and thickness of the rocks for a 
few hundred feet beneath the surface (see pl. 5), and records of churn drilling in search of oil and gas show the occurrence of beds of sand and supply meager information concerning the character of the strata to a depth of about 3,200 feet below the lowest outcrops, down to the lower part of the Chemung formation, of Upper Devonian age. (See pl. 8.) Some indication of the character of the rocks that lie beneath those yet reached by the drill in the New Kensington quad rangle is afforded by the records of two wells, each more than 7,000 feet deep, in adjacent areas. (See pp. 74-78.) An index of the still deeper strata is furnished by the rocks that crop out along the northern, eastern, and western margins of the Pittsburgh-Huntington Basin, where the formations that lie deeply buried in the central part of the basin are exposed at the surface. Although the deep-lying beds may differ in composition and thickness from the beds of the same formations along the outcrop, the outcropping rocks, in the absence of well records, afford an indication of what may be expected in deep drilling in the New Kensington quadrangle and will be helpful in interpreting the logs of wells. The marginal areas, sections of which are given on pages 79-83, are the following quadrangles, the geology of which has been described in reports of the United States Geological Survey, either published or in press: Columbus, Cleveland, Berea, and Euclid, Ohio; Niagara Falls, N. Y.; Warren, Somerset, Windber, Hollidaysburg, and Huntingdon, $\mathrm{Pa}^{2}$ The location of these quadrangles is shown on the index map.

The strata were deposited in the Appalachian geosyncline, an epicontinental marine basin that throughout the greater part of Paleozoic time was a down-warping area in which a mass of sediments having a maximum thickness of about 40,000 feet accumulated. The down-warping of the geosyncline, which in general kept pace with the deposition of the sediments, was interrupted many times during the Paleozoic era by regional uplift. These ups and downs and the corresponding retreats and advances of the sea produced hiatuses and overlaps; and because of the differences in local conditions under which the sediments were deposited the beds vary greatly in composition. While sand was being laid down in one area mud was accumulating in another and calcareous deposits elsewhere, resulting in the interfingering lenses that are characteristic of the strata of the Appalachian region. A very pronounced stratigraphic variation in this area is the general increase in the thickness of the sediments from west to east, in the direction of the old land mass Appalachia, which was the source of much of the sediments. In the

2 U. S. Geol. Survey Geol. Atlas, Columbus folio (No. 197), 1915; Niagara folio (No. 190), 1914; Warren folio (No. 172), 1910; Somerset-Windber folio (No. 224) (in press); Hollidaysburg-Huntingdon folio (No. 227) (in press). Cushing, H. P., and others, Geology and mineral resources of the Cleveland district, Ohio: U. S. Geol. Survey Bull. 818, 1931. 
area between central Ohio and the vicinity of the Allegheny Front in central Pennsylvania the thickness of the rocks of Devonian age increases from about 900 feet in the west to about 9,000 feet in the east.

\section{ROCKS NOT EXPOSED}

The formations that lie beneath the outcropping beds in the New Kensington quadrangle are known only in a general way, and because of the incompleteness of the records of the oil and gas wells they can not be described in detail or be sharply delimited. Most of the records of drill holes that have been put down in this quadrangle in search of oil and gas are in skeleton form and show only the oil and gas sands. (See well records, pp. 90-97, and pl. 8.) A few of the records, however, show the occurrence of shale lying between the sands, of local red beds, and beds of limestone and coal.

Although no very deep wells have been sunk in the New Kensington quadrangle, two of the deepest wells in the world, at the time they were put down, were drilled within a few miles of this area. One, the R. A. Geary well (Peoples Natural Gas Co. well No. 770) near McDonald, in Wushington County, about 15 miles southwest of the New Kensington quadrangle, was sunk in 1911-1917 to a depth of 7,248 feet to beds of Silurian (Salina) age; and the Booth \& Flinn well No. 3 (Peoples Natural Gas Co. well No. 1842) near Ligonier, Westmoreland County, 25 miles southeast of the New Kensington quadrangle, completed in 1925, attained a depth of 7,756 feet.

These wells were put down in search of the so-called "Clinton" sand (at or near the horizon of the "White Medina" = the Albion sandstone of New York and the Tuscarora quartzite of Pennsylvania, at the base of the Silurian system; see sections, pp. 79-83), which has yielded enormous quantities of oil and gas in Central Ohio and of natural gas in western New York. Because of the great increase in the thickness of the rocks from west to east, however, this objective of the deep drilling in southwestern Pennsylvania and northern West Virginia has not yet been attained. Some of the easternmost deep wells in which the "Clinton" sand has been found are the Derrick City well, in McKean County, northwestern Pennsylvania, ${ }^{3}$ in which the sand was found at a depth of 5,320 feet; the Reamer well, in Columbiana County, Ohio, 26 miles west of the Ohio-Pennsylvania boundary, in which the "Clinton" sand was struck at 5,576 feet beneath the surface;" and the Temple-

\footnotetext{
${ }^{3}$ White, I. C., Discussion of the records of some very deep wells in the Appalachian oil fields; Introduction to report on Barbour and Upshur Cointies and western portion of Randolph County, West Virginia Geol. Survey, 1918.

1 Stout, Wilber, and Lamborn, R. E., Geology of Columbiana County: Ohio Geol. Survey, 4th ser., Bull. 28, p. 369, 1924 .
} 


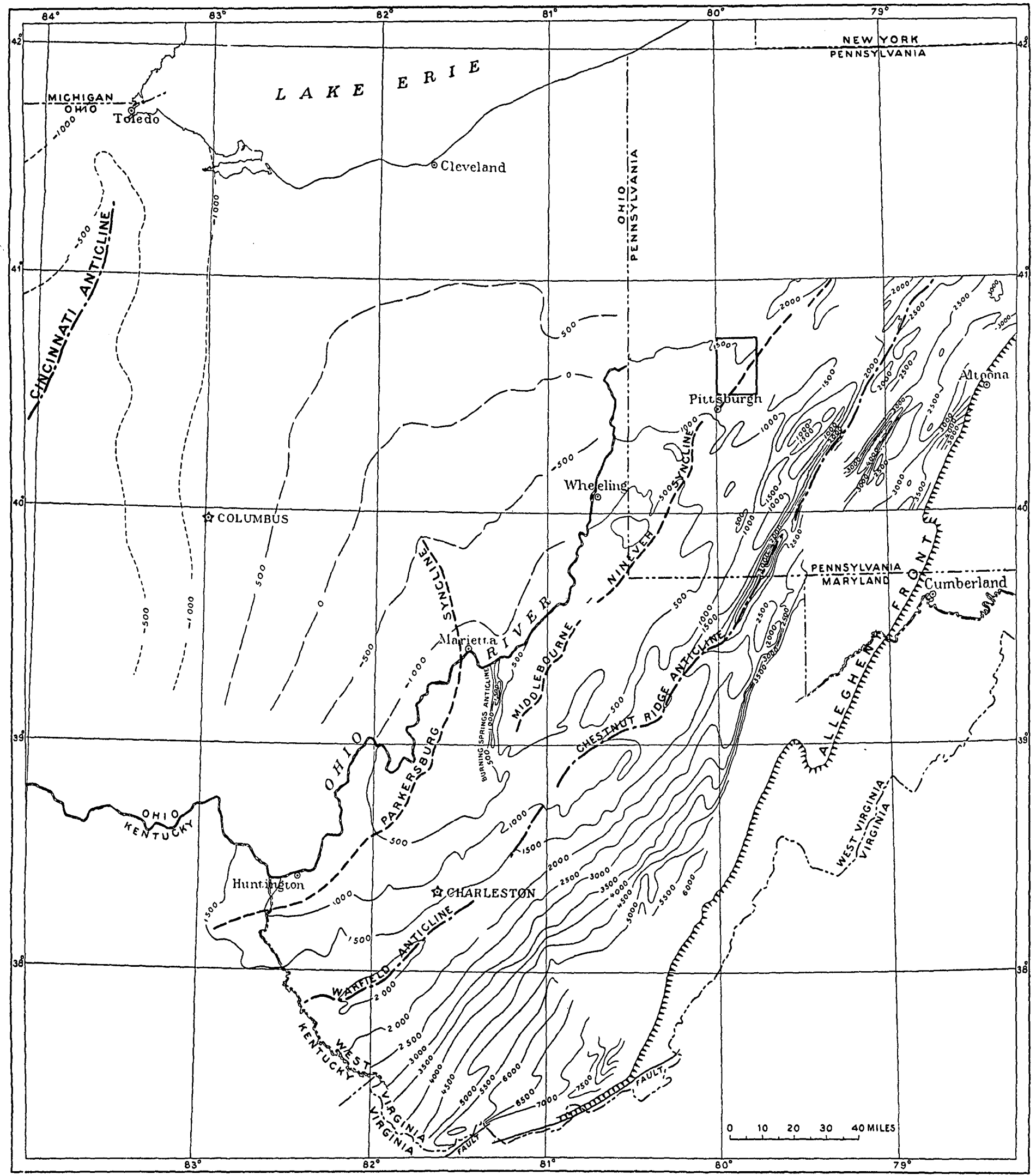

CONTOUR MAP SHOWING GENERALIZED GEOLOGIC STRUCTURE OF PART OF THE PITTSBURGH-HUNTINGTON BASIN Contours based on Pittsburgh coal in Pennsylvania and West Virginia, on Berea sandstone in eastern Ohio, and on Trenton (?) limestone in central Ohio. Contour interval
500 feet; datum mean sea level. Rectangle shows position of New Kensington quadrangle. 


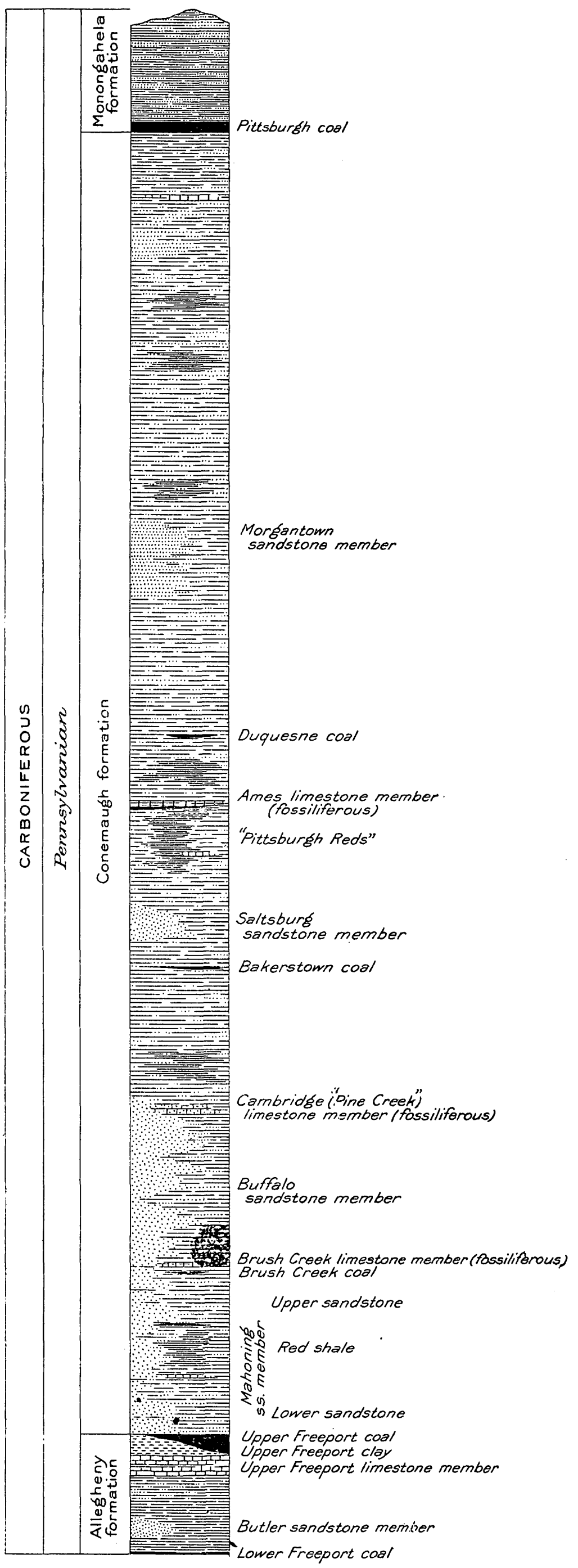
50

Vertical scale 


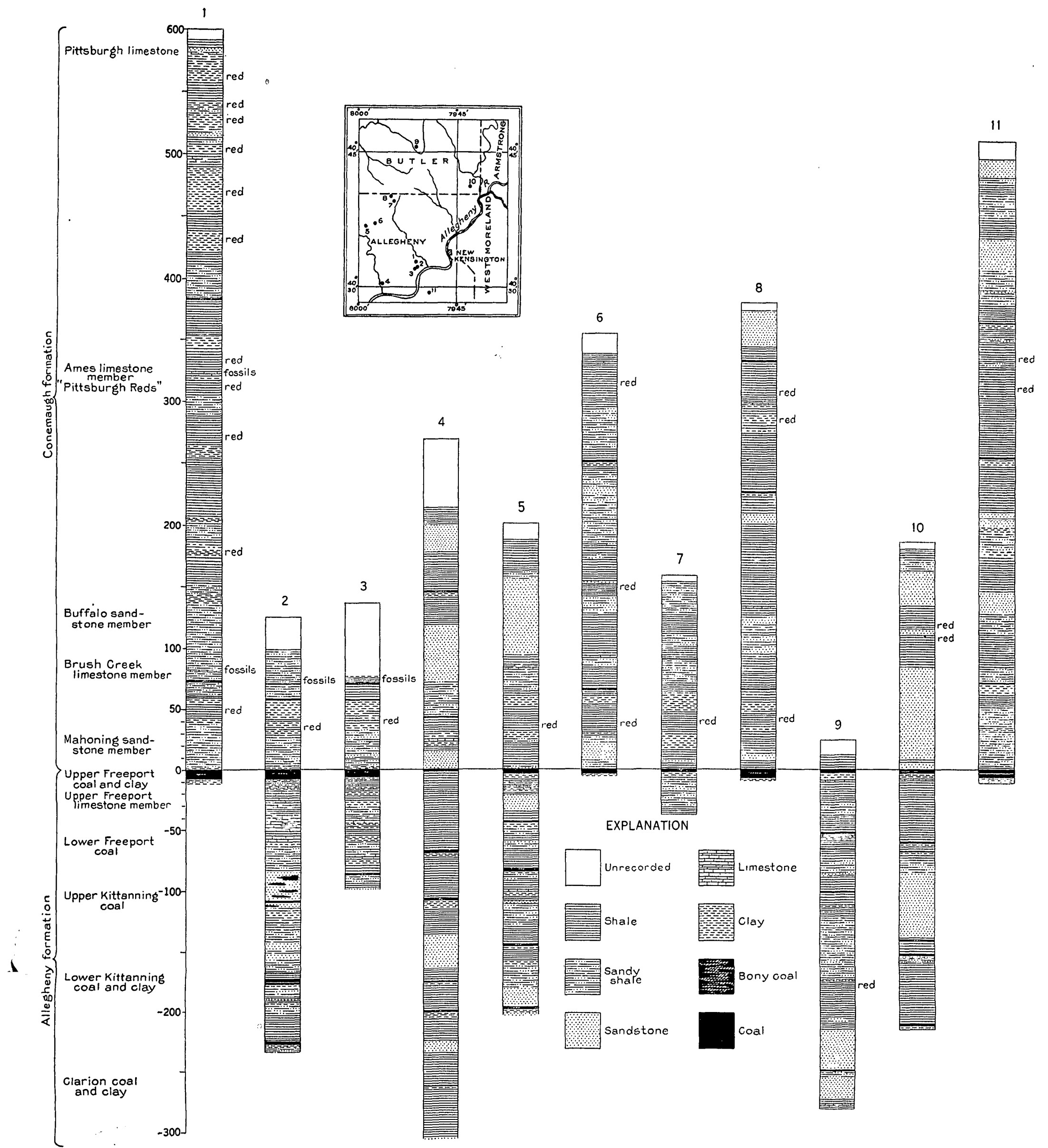

SECTIONS OF DIAMOND-DRILL HOLES IN THE NEW KENSINGTON QUADRANGLE 
ton well, in Cabell County, southwestern West Virginia, in which the sand occurs at a depth of 4,510 feet. $^{5}$

The records of the $\mathrm{McD}$ Donald and Ligonier wells are given on pages 74-78.

Sections of the rocks encountered in deep drilling in the New Kensington quadrangle, compiled from the records of oil and gas wells, are shown in Plate 8 , and the graphs are supplemented by the records of wells in the appendix (pp. 90-97). Core drilling of the oil and gas sands has not yet been done in this area, and the information available is not sufficient to classify the rocks; therefore, the lines of division between the formations and between the geologic eras are questioned on Plate 8.

Red beds, which are occasionally reported in the records as thin lenses of red shale or sandstone in a zone about 400 feet thick between the Hundred-foot and Fifth sands inclusive (see pl. 8 and list of oil and gas sands, p. 50), mark the westward thinning of the Catskill formation, which is well developed in western Pennsylvania, where along the Allegheny Front it is about 2,000 feet thick. The underlying beds down to the so-called Bradford sand, consisting of greenish-gray sandstone and shale, are correlated with the Chemung formation, of Upper Devonian age.

The rocks for about 600 feet above the Hundred-foot sand are tentatively assigned to the Pocono formation, of Mississippian age, although from the records it is impossible to determine where the line shall be drawn between the Mississippian and Upper Devonian series in the subsurface rocks. The attempt to do so at the present. time would be futile, inasmuch as paleontologists are not in agreement concerning the horizon at which the line shall be drawn between rocks of Carboniferous and Devonian age in the area of outcrop. The records show massive sandstone in the upper and lower parts of the interval assigned to the Pocono. The upper of these sands is known to the drillers as the Big Injun and the lower as the Murrysville or Butler County gas sand.

From the top of the Murrysville down through the Fifth sand of the drillers, in an interval of 500 to 600 feet, there is a group of lenticular beds consisting of preponderating sandstone and intervening. shale, which constitute the principal oil and gas sands of the quad-. rangle. These sands are described on pages 52-55. (See also table of oil and gas sands, p. 50.) As a whole the group of oil and gas sands is persistent throughout the quadrangle. When traced over larger areas, however, the beds are found to vary considerably. Eastward in the direction of the thickening of the sediments the beds.

\footnotetext{
- Reger, D. B., First test of the Clinton oil sand in West Virginia: Am. Inst. Min. and Met. Eng Trans., [preprint] 1447, pp. 72-77, April, 1925.
} $63318-32-2$ 
of sand composing this group lose their identity, and they are not recognized as such in the excellent exposures along the Allegheny Front. Westward the sands disappear and merge with shale in the general thinning of the section in that direction. In the vicinity of the Pennsylvania-Ohio boundary the sands below the Pocono formation thin out.

The Pottsville formation of Pennsylvanian age, which overlies the Pocono formation, is separated from it by an erosional unconformity marked by the absence of the intervening Loyalhanna limestone, Mauch Chunk shale, and lower part of the Pottsville formation. In western Pennsylvania the upper part of the Pottsville formation consists of two and locally three sandstone members separated by shale, in which thin lenses of coal and limestone occur, the whole averaging about 200 feet in thickness. The incomplete well records in the New Kensington quadrangle, however, show only sandstone at this horizon.

The Pottsville is conformably overlain by the Allegheny formation, which consists of a variable sequence of sandstone, shale, limestone, clay, and coal and averages about 300 feet in thickness. The Allegheny formation includes the beds that lie between the top of the Pottsville formation and the top of the Upper Freeport coal. These limits are arbitrary, and in places, where the members are poorly defined or attain unusual development, in the absence of paleobotanic evidence precise delimitation of the formation is impossible. The following are the principal subdivisions of the Allegheny formation, beginning at the top:

Upper Freeport coal.

Upper Freeport clay.

Upper Freeport limestone member.

Butler sandstone member.

Lower Freeport coal.

Lower Freeport limestone member.

Freeport sandstone member.

Upper Kittanning coal.

Middle Kittanning coal.
Lower Kittanning coal.

Lower Kittanning clay.

Kittanning sandstone member.

Vanport limestone member.

Clarion coal.

Clarion clay.

Clarion sandstone member.

Brookville coal.

The beds below the Lower Freeport coal are not exposed in the New Kensington quadrangle, and little is known of them in this area. Because the Upper Freeport coal has been the objective of the diamond drilling most of the core drills stop at that horizon. Several drill holes, however, have penetrated to the Kittanning coals and show the presence of thin variable beds, but not enough drilling has been done to determine whether any of the beds of coal below the Upper Freeport in this area are of workable thickness under present conditions. The Lower Kittanning coal, lying between 174 and 203 feet below the Upper Freeport coal, to judge from the scanty data available, seems to be the most persistent and promising 
of the coal beds below the Upper Freeport, but so far as the writer is aware the Lower Kittanning coal in this quadrangle is not more than 2 feet 6 inches thick, and further drilling is necessary to establish its value.

The Vanport limestone member of the Allegheny formation, which is of widespread distribution north of the New Kensington quadrangle, is reported in a few diamond-drill records and records of oil and gas wells in this area. (See pl. 8.) The limestone decreases in thickness southward and is locally absent in this quadrangle. It ranges in thickness from 10 feet down to the vanishing point and lies 245 to 278 feet below the Upper Freeport coal. The lower members of the Allegheny formation have not been recognized in this quadrangle.

\section{ROCKS EXPOSED}

CARBONIFEROUS SYSTEM

PENNSYLVANIAN SERIES

ALLEGHENY FORMATION

The entire area of the New Kensington quadrangle is underlain by the Allegheny formation, which crops out in the several isolated areas shown on the geologic map (pl. 1). The outcropping areas of the formation lie along the axis of the Amity anticline in the valley of the Allegheny River and its tributaries-Bull Creek and Wilson and Bailey Runs, in the vicinity of Tarentum; along the axis of the Kellersburg anticline in the valleys of Sarver Run, two of the upper tributaries of Bull Creek, and Pine Creek; and on the crest of the small anticline in the valley of Glade Run, in the northwest corner of the quadrangle.

In all these areas only the upper part of the formation is exposed, in most places only 50 feet or less. The greatest thickness of the Allegheny outcrop in the quadrangle is in the hills east of Bull Creek, about 2 miles north of 'Tarentum. There the Upper Freeport coal is 100 feet above the creek, but the lower part of the section is covered. When this area was examined by I. C. White in 1876 the Lower Freeport coal, 1 foot 6 inches thick, lying 62 feet below the Upper Freeport coal, was exposed in a drift in the valley of Bull Creek a mile above the mouth of Little Bull Creek, north of Tarentum.

The most valuable coal in the quadrangle is the Upper Freeport, which is one of the most valuable beds in the entire bituminous field. The type locality is at Freeport, $\mathrm{Pa}$., from which the coal bed has been traced along the bluffs of the Allegheny River, a distance of 6 miles, into the New Kensington quadrangle. In the vicinity of Freeport and in many places throughout the bituminous coal field the Upper Freeport coal is between 3 and 4 feet thick, but a short 
distance west of Tarentum and over a considerable part of the New Kensington quadrangle, in the area shown in Figure 4, the Upper Freeport coal averages more than 7 . feet and locally is 10 feet thick. In this area the coal is known as the "thick Upper Freeport bed." (See pl. 6.)

East of the area underlain by the thick Upper Freeport coal the bed is fairly uniform. Above a layer of soft clay is a bed of coal

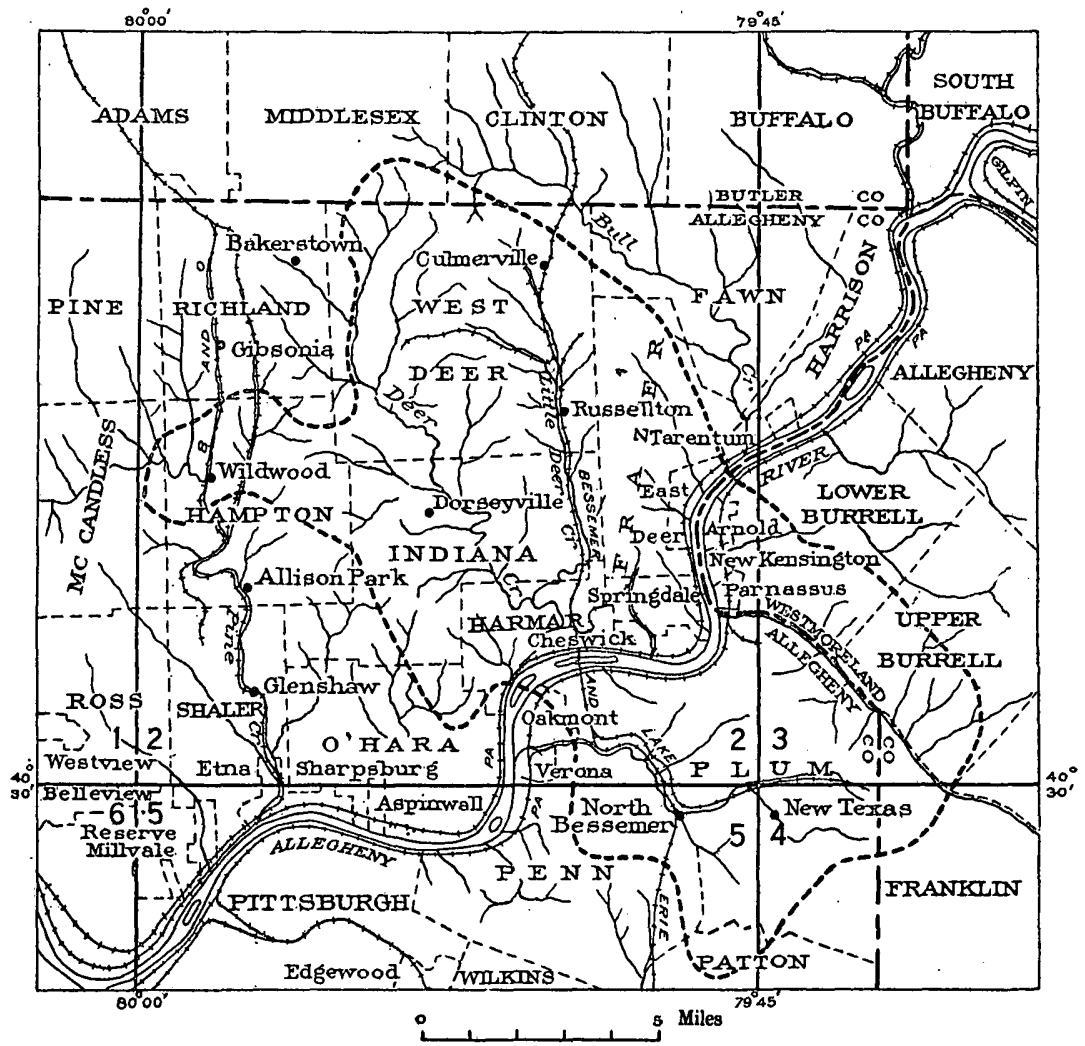

FIGURE 4.-Map showing approximate outline of area underlain by thick Upper Freeport coal (heavy dashed line). (After J. M. Rayburn.) 1, Sewickley quadrangle; 2, New Kensington quadrangle; 3, Freeport quadrangle; 4, Greensburg quadrangle; 5, Pittsburgh quadrangle; 6, Carnegie quadrangle

containing one or more thin layers of shale, above which is the main bench of coal, 28 to 36 inches thick. This is succeeded by bony coal, above which is shale. The transition to the thick bed is well exposed along the railroad on the south side of the Allegheny River between the tipple of the Valley Camp mine south of Tarentum and the brick plant. Immediately east of the Valley Camp tipple the following section is exposed: 
Section of Upper F'reeport coal and associated beds just east of tipple of Valley Camp mine

Conemaugh formation:

Ft. in.

Mahoning sandstone: Thin sandstone and sandy shale. $20+$

Allegheny formation:

Upper Freeport coal-

Cannel shale and coal.................... 210

Coal

Shale.......

Coal

Upper Freeport clay: Gray soft clay ............ $2 \quad 6$

Upper Freeport limestone-

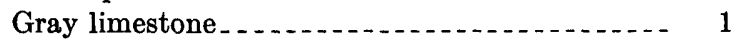

Gray clay shale............................ 16

Gray limestone (at railroad track) ............ 18

Along the railroad about 500 feet east of the section given above the following section is exposed:

Section of Upper Freeport coal and associated beds 500 feet east of tipple of Valley

Conemaugh formation:

Camp mine

Mahoning sandstone: Thin sandstone and sandy shale.

Allegheny formation:

Ft. in.

Coal (Upper Freeport coal)

Gray soft clay (Upper Freeport clay)

Limestone and shale (Upper Freeport limestone) _... $\quad 3 \quad 3 \quad 6$

In this interval the upper part of the coal bed at Valley Camp is represented by shale. Although there may have been local erosion of coal, apparently just beyond the margin of the deposit of thick coal mud was deposited instead of vegetable débris.

Except along the outcrops in the valley of the Allegheny River the limits of the thick bed of Upper Freeport coal are not exposed, but the boundary has been determined in some of the workings, as in the Creighton and Ford Colliery mines. The area that is underlain by the thick Upper Freeport coal has been prospected by diamond drilling and has been mapped by J. M. Rayburn, mining engineer, of Pittsburgh. $^{6}$ (See fig. 4.)

In a few places in the New Kensington quadrangle the Upper Freeport coal is missing, owing to nondeposition of the coal or to local erosion in Pennsylvanian time. A diamond-drill hole put down west of Oakmont and another near Glenover, both of which were sunk below the horizon of the Upper Freeport coal, failed to find it. The extent of the area in which the coal is absent, however, is not known. Another locality where the coal is apparently absent is in the valley of Pine Creek and its tributary Gourdhead Run, in Hampton Town-

\footnotetext{
B Rayburn, J. M., The deposit of double thick Upper Freeport coal situated in the valley of the Allegheny River: Eng. Soc. Western Pennsylvania Proc., vol. 40, pp. 27-44, 1924.
} 
ship, Allegheny County. The coal is present and has been mined at several places in the valley of Pine Creek between Mount Royal and Glenshaw, in Shaler Township, but the bed thins northward and seems to disappear between Mount Royal and Elfinwild and has not been reported in the area of outcrop of the Allegheny formation in Southern Hampton Township. The area in which the Upper Freeport coal is absent has not been determined, but in the vicinity of Wildwood the coal is present in thick development.

Elsewhere in the quadrangle, where the Allegheny formation crops out, the Upper Freeport coal is present and has been opened up in country banks, measurements in which are given on pages 32-40. Results of core drilling, details of which can not be published, are reported to indicate that in part of the quadrangle north of the divide that separates the drainage basins of the Allegheny River and Connoquenessing Creek the Upper Freeport coal in general is so thin as to have no present commercial value.

In about 20 per cent of the area occupied by the thick Upper Freeport coal, as reported by Rayburn, ${ }^{7}$ the upper part of the thick bed is cannel coal or cannel shale, sections of which are given on pages 83-85.

Underlying the Upper Freeport coal, in all the sections examined, is a few inches to 3 or 4 feet of soft gray clay, beneath which lies the Upper Freeport limestone. This limestone is a compact blue-gray bed which weathers buff and ranges from a few inches to 4 feet in thickness. It occurs interbedded with drab shale, and in places there are two beds of limestone at this horizon separated by a layer of shale. Along the road up the hill west of the railroad station at Elfinwild, for instance, the Upper Freeport limestone is well exposed. It consists of two beds about 18 inches thick separated by $2 \frac{1}{2}$ feet of drab shale. The following sections are typical:

Partial section of Allegheny formation at Elfinwild, Shaler Township, Allegheny County

$\begin{array}{llr}\text { Sandstone (Mahoning). } & \text { Ft. in. } \\ \text { Black shale } & 8 \\ \text { Coal (Upper Freeport) } & \\ \text { Clay } & \\ \text { Limestone } & \end{array}$

Partial section of Allegheny formation 1 mile above mouth of McDowell Run, Fawn Township, Allegheny County

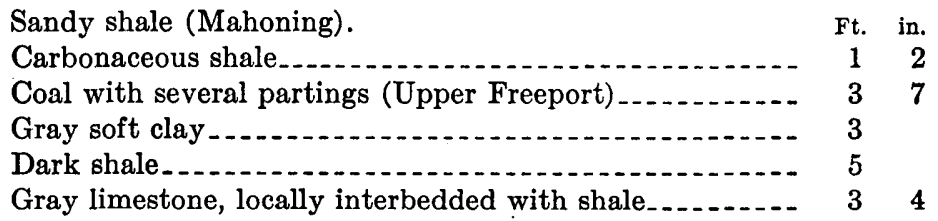

r Rayburn, J. M., op. cit., p. 20. 
Partial section of Allegheny formation above junction of Bailey and Wilson Runs, East Deer Township, Allegheny County

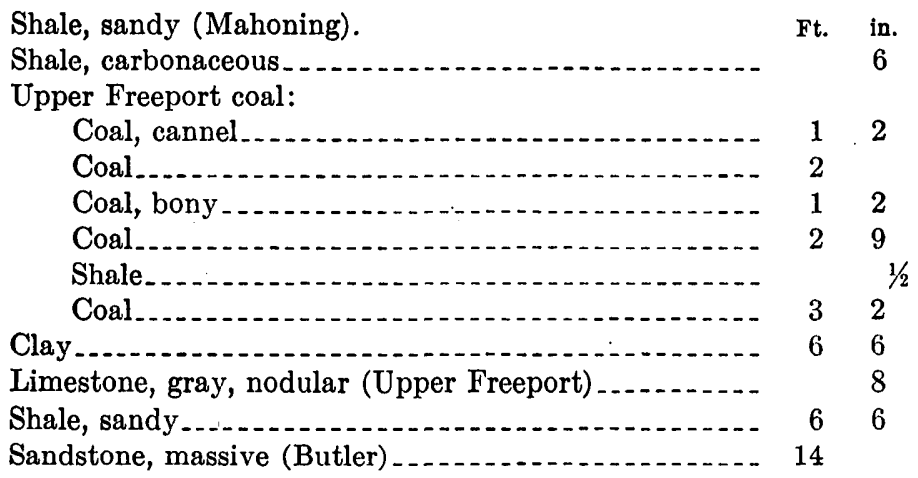

The Butler sandstone is a fine-textured gray lenticular bed, which is well developed in the area north of the New Kensington quadrangle, especially near the town of Butler.

\section{CONEMAUGH FORMATION}

Thickness and subdivisions.-The Conemaugh formation, which conformably overlies the Allegheny, consists of a variable sequence of shale, sandstone, and thin beds of limestone and coal lying between the Upper Freeport and Pittsburgh coal beds. The Conemaugh formation increases in thickness from west to east and ranges from 355 feet in Ohio to a little over 900 feet in Maryland. In the New Kensington quadrangle it is between 620 and 640 feet thick. It is characterized by several irregular bands of red beds and by the presence in its lower part of three calcareous zones containing marine fossils-the Ames, Cambridge ("Pine Creek"), and Brush Creek limestones. The formation has been subdivided into numerous members, of which the following named in descending order, are the principal ones that have been recognized in the New Kensington quadrangle:

Morgantown sandstone member.

Birmingham shale member (red).

Duquesne coal.

Ames limestone member.

Harlem coal.

"Pittsburgh Reds."

Saltsburg sandstone member.

\author{
Bakerstown coal. \\ Cambridge ("Pine Creek") Jimestone \\ member: \\ Buffalo sandstone member. \\ Brush Creek limestone member. \\ Mahoning sandstone member.
}

These members occur in the lower 450 feet of the formation. The upper 200 feet, which is present on only a few hills, is poorly exposed. A few diamond-drill records show that this upper part of the formation consists principally of thin sandstone and shale. The widespread and abundantly fossiliferous Ames and Brush Creek limestones and the locally well-developed fossiliferous Cambridge ("Pine Creek") limestone constitute the basis of correlation. 
Distribution and character.-By far the larger part of the surface of the New Kensington quadrangle is occupied by the Conemaugh formation, as shown by Plate 1. The only parts of the area from which the entire formation has been removed by erosion are the valleys in which the underlying Allegheny formation is exposed. The Conemaugh formation is covered by Quaternary sand and gravel in the valley of the Allegheny River, and on a few hilltops in the southern part of the quadrangle the formation is capped by rem. nants of the Monongahela formation, with the Pittsburgh coal at its base. It is only in areas where the Monongahela caps the Conemaugh formation that its entire thickness is preserved, and records of diamond-drill holes show that in those areas the Conemaugh is between 620 and 640 feet thick. The Ames limestone, which lies near the middle of the Conemaugh, crops out along the hillsides and forms the intricate pattern shown on the geologic map.

Relations of the Allegheny and Conemaugh formations.-The Allegheny and Conemaugh formations are structurally conformable, but in places there is evidence of possible local erosion at the base of the Conemaugh. The lowermost beds of the Conemaugh in the New Kensington quadrangle are variable. In some places the Upper Freeport coal is immediately overlain by carbonaceous clay shale, in others by gray sandy shale, and in still others by sandstone. Where the Upper Freeport coal changes from its thick development to its more normal thickness of about 3 feet, the horizon corresponding to the uppermost part of the thick bed is represented by clastic sediments. For instance, east of the Valley Camp mine, across the river from Tarentum, the upper layers of the thick coal bed exposed above the railroad track are represented to the east, beyond the limits of the thick beds, by shale; and in the mine of the Ford Colliery Co. near Culmerville, in West Deer Township, the uppermost part of the thick coal bed gives way to sandstone. It is not clear whether at these places there was erosion of the thick Upper Freeport coal bed, or whether its present extent practically corresponds with the area of the swamp in which the unusual thickness of carbonaceous deposits accumulated and at the margin of which mud or sand replaced the vegetal matter of the swamp.

Mahoning sandstone member.-The basal 70 to 100 feet of the Conemaugh, that part of the formation which lies below the Brush Creek limestone, includes the Mahoning sandstone member. This part of the formation consists chiefly of sandy shale, clay shale, and sandstone. In many areas a threefold division of the Mahoning is caused by the presence near the middle of the member of a zone of variable beds including a thin bed of coal-the Mahoning coal-and variegated red and gray to black sandy and clay shale.

The red shale of the Mahoning. sandstone member is widespread in the quadrangle and serves as a useful horizon marker. It lies be- 
tween 30 and 50 feet above the Upper Freeport coal and ranges in thickness from 4 to 12 feet. The beds, which consist of variegated red and gray sandy and clay shale, mark the lowest occurrence of red beds in the Conemaugh formation. The Mahoning coal, a commercially worthless bed, ranging from about an inch to $1 \frac{1}{2}$ feet in thickness, is of variable occurrence 50 to 60 feet above the Upper Freeport coal. This coal is interbedded in a mass of sandy and clay shale which in places, as just east of the Valley Camp mine (No. 10 on the map) and above the Cornell and McFetridge Bros. mines (Nos. 8 and 9), is utilized for making common brick.

A lens of limestone (the Gourdhead Run limestone of I. C. White) crops out locally in the valley of Gourdhead Run, in Hampton Township. It has not been found elsewhere. At this locality the Upper Freeport coal is apparently absent, but the presence of the Brush Creek and Upper Freeport limestones serve to determine the stratigraphic position of this lens. It lies about 30 feet above the Upper Freeport limestone and 50 to 60 feet below the fossiliferous bed at the Brush Creek horizon and therefore occurs in the interval occupied by the Mahoning sandstone member. This limestone is a compact, fine-textured buff and dark rock, in which fossils have not been found and which has a maximum observed thickness of 3 feet.

Thick beds of sandstone in the Mahoning member in this area are rare, but in the extreme northeast corner of the quadrangle, in Winfield and Buffalo Townships, Butler County, in the valley of Little Buffalo Creek, there is a mass of sandstone about 130 feet thick. This includes the upper part of the Mahoning sandstone member and the Buffalo sandstone member. The Brush Creek limestone and Brush Creek coal, which normally occur between these sandstones, are locally absent. The top of this mass of sandstone is about 150 feet above the Upper Freeport coal, which at the railroad siding at the stone quarry is reported to occur 30 feet below the bed of the creek. The uppermost layers of the sandstones are thin-bedded and flaggy, and the middle and lower parts are massive and locally conglomeratic, with pebbles of quartz as much as a quarter of an inch in diameter. The main mass of the sandstone is a fine-textured grayish rock, weathering buff, and consists primarily of quartz and feldspar with secondary muscovite and kaolin. Variable layers of shale are interbedded with the sandstone, and a few miles to the southwest, in the valley of Sarver Run, much of the sandstone that is so well developed in the valley of Little Buffalo Creek is represented by sandy shale.

Brush Creek limestone member.-The Brush Creek limestone, lying between the Mahoning and Buffalo sandstone members, was named by I. C. White ${ }^{8}$ from its occurrence in the valley of Brush Creek in Cranberry Township, Butler County. This limestone is one of the

8 White, I. C., Pennsylvania Second Geol. Survey Rept. Q, p. 74, 1878. 
notable fossiliferous beds of the Conemaugh formation and has a widespread distribution in Ohio, Pennsylvania, West Virginia, and Maryland.

In the New Kensington quadrangle the interval between the Mahoning and Buffalo sandstones is occupied chiefly by shale, the thickness of which, varying with the development of sandstone in the overlying and underlying members, averages possibly 30 feet. The lower part of the Brush Creek member is commonly a fine-grained fissile dark shale, and the upper part is lighter in color and more sandy. The shale is commonly calcareous, and in places nodules and thin lenses of dark limestone are present. The limestone and shale in most places are abundantly fossiliferous. In some sections the fossils are most abundant in a zone only a few inches thick, and in others the fossils occur throughout a thickness of 20 to 30 feet. The most abundantly fossiliferous beds in the Brush Creek member in the New Kensington quadrangle occur between 70 and 90 feet above the Upper Freeport coal. The best exposure of these beds in this quadrangle is in the stripping of the old quarry and clay pit in the face of the bluff west of Pine Creek, just north of Wittmer station on the Baltimore \& Ohio Railroad, where the Cambridge ("Pine Creek") and Brush Creek fossiliferous beds are well developed. The following list of fossils collected at this horizon was prepared by George H. Girty. The Foraminifera and ostracodes were identified by P. V. Roundy.

Ammodiscus n. sp.

Spirillina? n. sp.

Haplophragmium n. sp.

Archeodiscus n. sp.

Lophophyllum profundum.

Serpulopsis insita.

Derbya crassa.

Chonetes verneuilianus?

Productus semireticulatus. pertenuis.

Pustula nebraskensis.

Marginifera splendens.

Spirifer triplicatus.

Ambocoelia planiconvexa.

Composita subtilita.

Solenomya parallela?

Edmondia sp.

Nucula parva.

sp.

Anthraconeilo taffiana.

Aviculipecten? herzeri.

Deltopecten occidentalis?

Lima n. sp.

Schizodus sp.
Pleurophorus oblongus.

Astartella concentrica.

Pharkidonotus percarinatus.

Euphemus carbonarius.

Pleurotomaria insecta.

Orestes nodosus?

Worthenia tabulata.

Pleurotomaria n. sp.?

Schizostoma catilloides.

Aclisina quadricarinata?

Cyclonema n. sp.

Zygopleura n. sp.

Spherodoma ventricosa.

aff. S. medialis.

aff. S. intercalaris.

aff. S. primigenia.

Bulimorpha chrysalis?

Naticopsis scintilla.

Pseudorthoceras knoxense.

Nautilus several sp.

Goniatites sp.

Griffithides sp.

Bairdia $4 \mathrm{sp.}$

Ostracode, n. gen., n. sp. 
A coal bed, known as the Brush Creek coal, in many places in the Appalachian Plateau underlies the Brush Creek limestone, but in the New Kensington quadrangle it occurs only locally, and no coal of value is known at that horizon.

Buffalo sandstone member.-Between the Brush Creek and Cambridge ("Pine Creek") limestones lies the Buffalo sandstone, which is locally prominent. In some places this stratigraphic interval is represented by beds of massive sandstone, and in other places almost entirely by shale. In the New Kensington quadrangle the Buffalo sandstone is generally well developed, and where it crops out it usually forms precipitous cliffs. It is best developed at the type locality along Buffalo Creek, in Butler County. In the northeast corner of the quadrangle, along Little Buffalo Creek, in the absence of the Brush Creek limestone, the upper part of the Mahoning sandstone and the Buffalo sandstone locally constitute a continuous mass of sandstone about 130 feet thick. The Buffalo sandstone, however, is lenticular and variable. In some sections it is present as a massive bed 30 feet thick, and in another near-by section it may be represented by sandy shale. Thus, in the valley of Pine Creek, where in general the Buffalo sandstone is well developed, it is conspicuous at the base of the cliffs bordering Pine Creek in the vicinity of Undercliff. Here the Buffalo sandstone is a fine-grained arkosic rock ranging from 20 to 30 feet in thickness and from massive to thinbedded. Cross-bedding is locally developed, but in the old clay workings at Wittmer, where the section is well exposed and where both Brush Creek and "Pine Creek" fossils were collected, the massive sandstone has disappeared and its place is taken by shale. Some confusion in nomenclature of sandstones in the lower half of the Conemaugh formation has been caused by the fact that at the type localities of the Buffalo and Saltsburg sandstones those members are unusually well developed and occupy a stratigraphic interval to parts of which other names are given in other localities. Thus the Buffalo and Mahoning and the Saltsburg and Buffalo in the type localities of the Buffalo and Saltsburg sandstones respectively merge into each other and replace the Brush Creek and "Pine Creek" limestones. In most places, however, these sandstones are not nearly so thick as at the type localities, and in general they are distinct units. In most places the widespread Brush Creek and "Pine Creek" fossiliferous limestones serve to separate and to identify these sandstones.

Cambridge ("Pine Creek") limestone member.-The "Pine Creek" limestone was named by I. C. White ${ }^{9}$ from its occurrence in the hill between Gourdhead Run and Pine Creek in Hampton Township, Allegheny County, in the New Kensington quadrangle. This lime-

- White, I. C., op. cit., p. 160. 
stone is correlated with the Cambridge limestone of Ohio, which is of widespread occurrence in the Conemaugh formation of Ohio, Pennsylvania, West Virginia, and Maryland, and it is now commonly called Cambridge limestone.

In the New Kensington quadrangle the Cambridge limestone lies between 70 and 90 feet above the Brush Creek limestone and between 140 and 165 feet below the Ames limestone. It is lenticular and variable and is not present in all sections, although it may easily escape attention in poor exposures. It is well exposed in the valley of Pine Creek. At Etna it crops out at the level of the Baltimore \& Ohio Railroad tracks opposite the Spang-Chalfonte mill and rises northwestward along the flanks of the Kellersburg anticline. In the vicinity of Etna the Cambridge is a massive arenaceous blue limestone between 18 inches and 2 feet thick, which weathers buff, and the leached limestone causes the sand grains to become so prominent that the rock resembles a sandstone. Here it is underlain by the Buffalo sandstone. Farther north the sandstone is replaced by shale, and at Wittmer the entire interval between the Brush Creek and "Pine Creek" limestones is occupied by shale. At the abandoned quarry and clay pit in the bluff on the west side of Pine Creek immediately north of Wittmer the Cambridge "Pine Creek" limestone, 2 feet thick, occurs in the midst of fissile black shale. At this locality the interval between the limestone and the richly fossiliferous beds of shaly limestone containing Brush Creek fossils is 69 feet.

The following fossils identified by G. H. Girty and P. V. Roundy were collected from the limestone at this locality.

Ammodiscus n. sp.

Archeodiscus? sp.

Haplophragmium n. sp.

Lophophyllum profundum.

Crinoidal parts.

Septopora biserialis.

Rhombopora lepidodendroides.

Derbya crassa.

Chonetes verneuilianus.

Productus cora.

pertenuis.

Pustula nebraskensis.

Spirifer triplicatus.

Ambocoelia planiconvexa.

Composita subtilita.

Edmondia ovata? ovata? var. levis? gibbosa?

Nucula wewokana?

Nuculopsis ventricosa.
Leda arata? meekana.

Acanthopecten carboniferus.

Lima n. sp.?

Astartella concentrica.

Phanerotrema grayvillense.

Orestes nodosus?

Meekospira peracuta?

Glaphurochiton carbonarius?

Pseudorthoceras knoxense.

Orthoceras sp.

Nantius (fragments of several species).

Griffithides sp.

Amphissites centronatus. n. sp.

Bairdia, 5 sp.

Ostracode n. gen., n. sp.

Hollina n. sp.

Paraparchites? sp.

Conodonts, 2 sp. 
Bakerstown coal.-The Bakerstown coal was named by I. C. White ${ }^{10}$ from occurrences of this bed in mines on the outskirts of the village of Bakerstown, Richland Township, Allegheny County, in the New Kensington quadrangle. This coal occurs between 60 and 90 feet below the Ames limestone and is lenticular and variable. In the New Kensington quadrangle it apparently attains its maximum development in the vicinity of Bakerstown, where it is between 2 and 3 feet thick. The Bakerstown coal has a widespread distribution, but at most other places in the New Kensington quadrangle outside of the type locality it is represented by only a few inches of coal, and locally it is absent from the section. Detailed measurements of this bed are given in the section relating to coal (pp. 40-41).

Saltsburg sandstone member.-The Saltsburg sandstone, named from Saltsburg, Indiana County, $\mathrm{Pa}$., lies between the Bakerstown coal and the "Pittsburgh Reds." In the New Kensington quadrangle it is represented chiefly by sandy shale and thin beds of sandstone, but in places, as in Shaler and Hampton Townships, in the southwestern part of the quadrangle, a massive sandstone 20 to 30 feet thick is present at this horizon.

"Pittsburgh Reds."-The most conspicuous and widespread development of red shale in the New Kensington quadrangle occurs near the middle of the Conemaugh formation below the Ames limestone. This band of variegated red sandy and clay shale ranges from a few feet to about 35 feet in thickness. In some places there is a continuous mass of red shale, and in others the red shales are interbedded with drab and buff shale, but some red beds at this horizon are persistent throughout the quadrange.

A lens of limestone in the midst of this red shale is locally present in the New Kensington quadrangle. It is well exposed $1 \frac{1}{2}$ miles south of Cooperstown, in Middlesex Township, where a band of limestone consisting of nodules. 2 to 4 inches thick of compact gray limestone that weathers buff is interbedded in red clay shale. A section here shows that this nodular limestone lies 29 feet below the Ames limestone, the interval being occupied entirely by red shales, the Harlem coal being locally absent.

Harlem coal.-A layer of carbonaceous shale or coal only a few inches thick occurs almost directly beneath the Ames limestone and marks the presence of the Harlem coal. In the New Kensington quadrangle it is not commercially valuable and is not everywhere present, but its occurrence here is another evidence of the widespread development of the Harlem coal in the Appalachian region.

Ames limestone member.-The fossiliferous Ames limestone is the most persistent and stratigraphically the most notable member of

10 White, I. C., op. cit., p. 162. 
the Conemaugh formation. The type locality is in Ames Township, Athens County, Ohio, from which it was named by E. B. Andrews in 1873. It is also known by the descriptive terms "crinoidal" and "green fossiliferous" limestone, but the name Ames has long been in general use for it in Ohio, Pennsylvania, West Virginia, and Maryland.

The Ames limestone lies near the middle of the Conemaugh formation throughout its extent, maintaining this position with the increasing thickening of the formation toward the east. In the New Kensington quadrangle the Ames fossiliferous bed is persistent and occurs between 315 and 330 feet above the Upper Freeport coal. Its outcrop is widespread throughout the quadrangle, as shown on the map, and altitudes on this bed, obtained by the use of the plane table and telescopic alidade, form the basis of the structure contours in areas where direct measurements on the Upper Freeport coal were not obtained. Although generally inconspicuous because of its thinness, the outcrop of this characteristic fossiliferous bed was usually found by the field method used. The approximate position of the Ames limestone and tentative structure contours drawn on the planetable sheets, on which the topographic base was reproduced on an enlarged scale, were kept just ahead of field mapping, so that the probable position of the outcrop was always determinable within a few feet in advance of actually finding it. By this method it was comparatively easy to locate fragments of fossiliferous rock on the hillsides, and these fragments were then followed to the outcrops, the altitudes of which were obtained.

The Ames limestone in the area here considered consists of greenishgray siliceous limestone or calcareous shale that breaks with a.characteristic granular fracture and ranges in thickness from 2 to 5 feet. Locally it is separated into two beds by calcareous greenish-gray shale. It lies directly on the Harlem coal or where that is not present the Ames is underlain by the "Pittsburgh Reds." In some places the Ames is immediately overlain by drab sandy shale and in others by red shale.

The Ames member carries a rich marine fauna containing abundant Ambocoelia planiconvexa. The following list compiled from several collections from the New Kensington quadrangle was supplied by George H. Girty.

Lophophyllum profundum.

Schizophoria n. sp.

Derbya bennetti?

Chonetes aff. C. choteauensis.

Productus semireticulatus.

Productus cora.

Productus pertenuis.
Marginifera splendens.

Pugnoides osagensis.

Spirifer triplicatus.

Ambocoelia planiconvexa.

Composita subtilita.

Hustedia mormoni.

Platyceras sp. 
Duquesne coal.-Two beds of coal are locally present in the sandy shales that lie between the Ames limestone and the Morgantown sandstone in the vicinity of Pittsburgh. Both of them at one time or another have been called the Elk Lick, and to avoid confusion Raymond ${ }^{11}$ proposed the name Duquesne coal for the lower bed. The upper bed has not been recognized in the New Kensington quadrangle, and the Duquesne coal is poorly developed and of no commercial value. Locally the horizon of the Duquesne coal is represented by carbonaceous shale.

This coal is exposed along the road a quarter of a mile northeast of the Sandy Hill School, in Middlesex Township, Butler County, where 2 feet of carbonaceous shale and bony coal are present 20 feet above the Ames limestone. In a few diamond-drill records the Duquesne coal, between 5 and 14 inches thick, is reported between 30 and 35 feet above the Ames.

Birmingham shale member.-In some sections variegated red sandy shale lies between the Duquesne coal and the Morgantown sandstone, but commonly this interval in the New Kensington quadrangle is occupied by gray sandy shale. Marine fossils have been found in the Birmingham shale, marking the highest horizon at which there is evidence of marine conditions in this region. The overlying beds are of brackish-water or fresh-water origin.

Morgantown sandstone member and overlying rocks.-The Morgantown sandstone is represented in this area by gray sandy shale and thin beds of sandstone, which form the upper part of several of the hills in the New Kensington quadrangle. The beds above the Morgantown are present only in the few high hills on which the Pittsburgh coal occurs, and exposures are poor. The rocks in this interval are chiefly buff sandy and clay shale interbedded locally with variegated red shale. A record of a diamond-drill core shows a bed of limestone 6 inches thick 38 feet below the Pittsburgh coal. This is one of several lenses lying within 70 feet below the Pittsburgh coal to which the name Pittsburgh has been applied.

\section{MONONGAHELA FORMATION}

The Conemaugh is overlain, with slight erosional unconformity, by the Monongahela formation, which ranges in thickness in southwestern Pennsylvania from 200 to 400 feet and includes the beds between the base of the Pittsburgh coal and the top of the Waynesburg coal. The Monongahela is well developed in southwestern Pennsylvania and presumably once covered the New Kensington quadrangle, but only a few hilltops in the southern part of this area are now capped by erosion remnants containing less than 100 feet of the

\footnotetext{
11 Raymond, P. E., A preliminary list of the fauna of the Allegheny and Conemaugh serfes In western Pennsylvania: Carnegie Mus. Annals, vol. 7, p. 149, 1910.
} 
formation. The largest area is less than 1 square mile, in Plum Township, southeast of Logans Ferry. Other localities are Rich Hill, in Indiana and West Deer Townships, and isolated hills in East Deer, Harmar, O'Hara, and Plum Townships, all in Allegheny County. These erosion outliers of the Monongahela formation contain remnants of the Pittsburgh coal bed.

The Pittsburgh coal, which lies at the base of the Monongahela formation, is the most valuable coal bed in western Pennsylvania. Throughout a large area it is a double bed, consisting of a roof division and a lower division. The roof division, which ranges from solid coal to laminations of coal, clay, and shale, is from 1 to 12 feet thick and is separated from the main coal below by an "over" clay a few inches to 2 feet thick. The lower or "main" division, the most valuable part of the bed, is commonly separated by thin partings into four benches, called the "breast," "bearing in," "brick," and "bottom" coals. The thickness of the "main" bed in Pennsylvania averages about 7 feet.

In the New Kensington quadrangle the Pittsburgh coal has been opened up and mined in country banks in most of the isolated occurrences, and the coal has been practically mined out. The tonnage was too small to justify railroad construction and the development of shipping mines. When the present survey was made only a few country banks were in operation on the Pittsburgh coal, and in these the full thickness of the bed was not exposed. The following sections were measured by I. C. White and J. J. Stevenson, of the Second Geological Survey of Pennsylvania:

Section of Pittsburgh coal in Plum Township, Allegheny County ${ }^{13}$

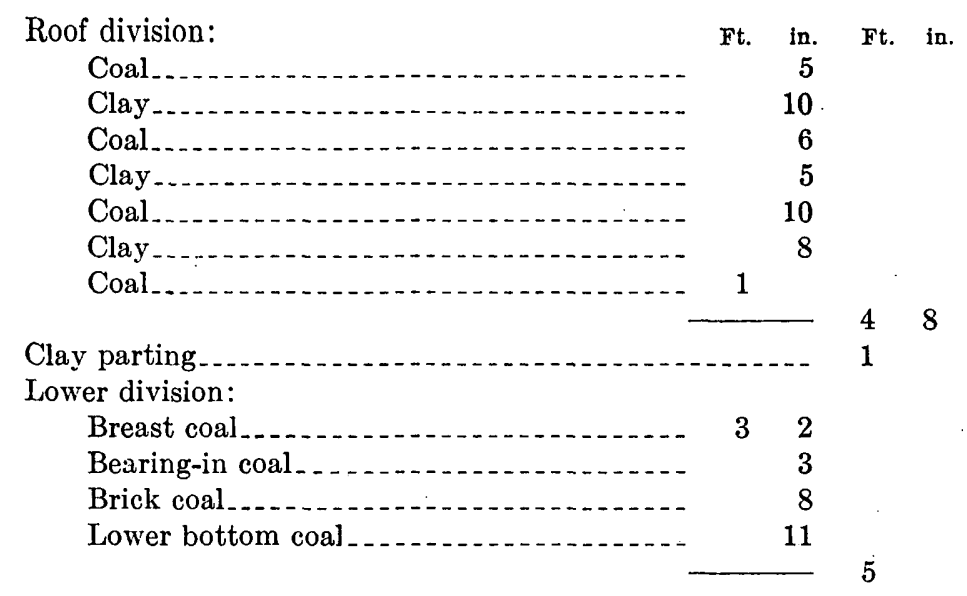

12 Stevenson, J. J., Report of progress in the Fayette and Westmoreland district: Pennsylvania Second Geol. Survey Rept. $K^{2}$, pt. 1, p. 390, 1877. 


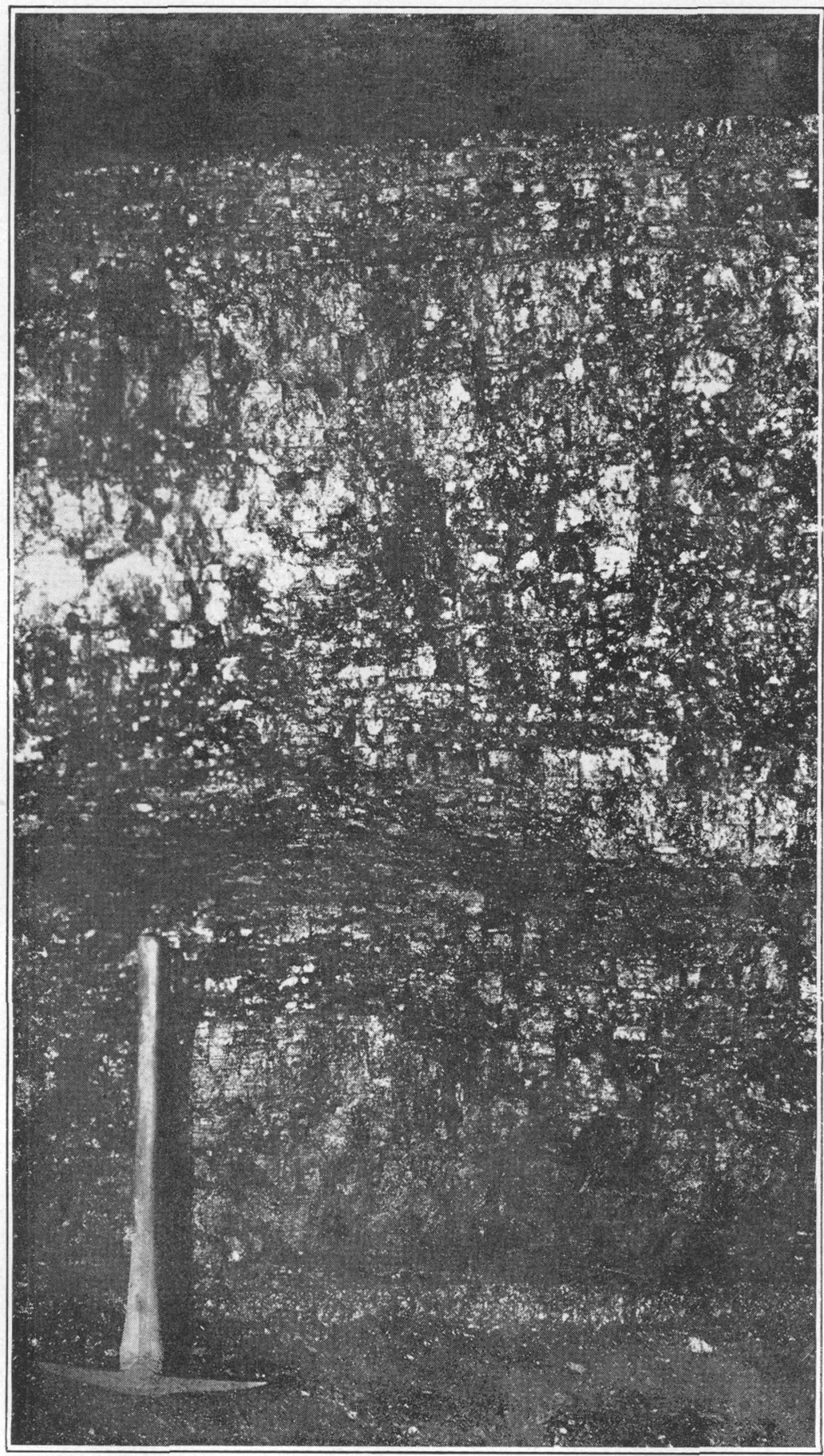

THICK UPPER FREEPORT COAL IN A MINE IN THE NEW KENSINGTON QUADRANGLE

Photograph reproduced by courtesy of Pennsylvania Topographic and Geologic Survey 




\begin{tabular}{rrrrrr}
0 & 5 & 10 & $\begin{array}{c}\text { SCALE } \\
15\end{array} \quad 20 \quad 25 \quad 30$ & MILES \\
\hline
\end{tabular}

STRUCTURE CONTOUR MAP OF SOUTHWESTERN PENNSYLVANIA

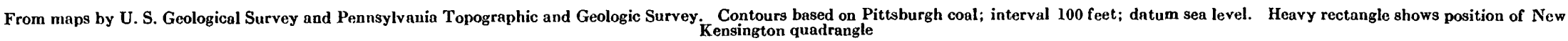


Section of Pittsburgh coal in Rich Hill, Indiana Township, Allegheny County ${ }^{13}$

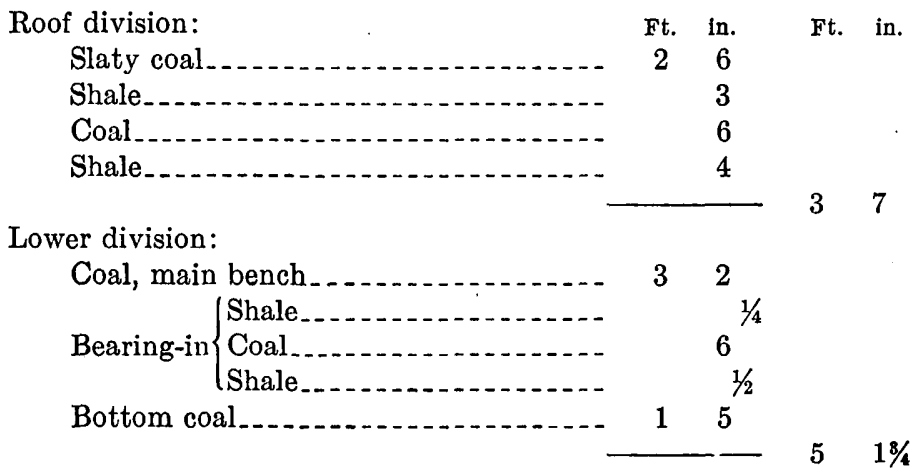

The beds that overlie the Pittsburgh coal in this quadrangle, consisting chiefly, if not entirely, of sandy shale, are poorly exposed. In places in Allegheny County the Redstone coal occurs about. 70 feet above the Pittsburgh bed, but it has not been recognized in this quadrangle.

\section{QUATERNARY SYSTEM}

\section{PIEISTOCENE AND RECENT SERIES}

General features.-There is no sedimentary record in western Pennsylvania of the long time interval between the Carboniferous and Quaternary periods. If any sediments were deposited in this area during Triassic, Jurassic, Cretaceous, or Tertiary time they have been removed by erosion. In the Quaternary period, however, in middle (?) and late Pleistocene time, gravel-capped terraces were formed in the valley of the Allegheny River, and some high-lying gravel recently discovered by Leverett in the vicinity of the mouth of the Beaver River and elsewhere in northwestern Pennsylvania indicates still earlier glaciation in this region. The deposits of alluvium in the flood plains of the larger streams are of Recent age.

During the Tertiary period the northern Appalachian region was reduced by erosion almost to a plain, remnants of which are represented in the New Kensington quadrangle by the hilltops that rise to altitudes between 1,200 and 1,400 feet. This peneplanation was followed by uplift and renewed erosion, and by the end of Tertiary time the topography of the quadrangle was developed to a stage much like that of the present. Subsequent changes have been most pronounced in the valley of the Allegheny River.

Early in the Quaternary period the Allegheny River, below the Clarion, was cutting a graded channel in bedrock when the advance of the first of the glaciers that covered the northern part of the con-

\footnotetext{
1s White, I. C., Report of progress in the Beaver River district: Pennsylvania Second Geol. Survey Rept. Q, p. 153, 1878.
}

$63318-32-3$ 
tinent materially changed conditions. The glacial front extended from the vicinity of Salamanca, N. Y., southwestward across northwestern Pennsylvania, past Warren, Tidioute, and Franklin, and north of Beaver.

There were at least three stages at which the ice sheets invaded northwestern Pennsylvania, and these alternated with interglacial stages when the ice melted away. Only a brief outline of the complicated glacial history will be presented here. From recent investigations in northwestern Pennsylvania Frank Leverett ${ }^{14}$ states that "the main high-level glacial gravel deposits on the Beaver, Allegheny, and. upper Ohio, as well as the main part of the pre-Wisconsin drift of northwestern Pennsylvania, are now interpreted to be of Illinoian age." During this stage of glaciation (middle Pleistocene) more than 120 feet of sand and gravel was deposited in the pre-Illinoian Allegheny Valley. After the gravel was deposited the stream began excavation, and much of the unconsolidated material was washed away, leaving only remnants of the deposit, which now form the conspicuous upper terrace along the sides of the valley. The river, in the New Kensington district, cut down to a depth of about 230 feet below the old rock bottom upon which it flowed in early Pleistocene time, and it was cutting a new gradient on rock about 50 feet below the present bed of the river when the work was interrupted by another advance of the ice at the Wisconsin stage of glaciation. Again the river was overburdened and aggraded its valley with sand and gravel. After the final retreat of the ice the stream resumed excavation and removed most of the later accumulation of sand and gravel, leaving remnants. of its former extent along the valley sides.

Illinoian (?) glacial deposits.-The deposits of Illinoian (?) glacial age in the New Kensington quadrangle consist of gravel, sand, and clay that form the main high terrace in the valley of the Allegheny River. The base of these deposits is the bench of bedrock that formed the graded bed of the river at the period preceding the deposition of the gravel, and the top of the terrace slopes with the river. The bench of bedrock at the base of the high terrace. has been traced for many miles-from the mouth of the Clarion River down past the mouth of the Beaver River. In the New Kensington quadrangle the altitude of this graded rock bed is between 910 and 925 feet above sea level.

In this quadrangle the Illinoian (?) glacial gravel forms the several even-topped, disconnected benches situated north of Tarentum, east of Valley Camp, New Kensington, Oakmont, and Verona, and north of Springdale and Acmetonia, shown on Plate 1. The deposits range from a few feet to 120 feet in thickness, and their greatest development is in the hills north of Springdale and east of Valley Camp.

14 Report of committee on sedimentation, National Research Council, p. 46, 1927. 
Nowhere is a complete section exposed. Sand and gravel, irregularly stratified, predominate, and on the hill north of Springdale the deposit is capped by silt. The material composing these deposits is principally of local origin, but there are also waterworn pebbles derived from sources far to the north. A characteristic feature of these terrace deposits is that some of the pebbles, which are mostly between 1 and 2 inches in diameter but some of which are as much as 10 inches, consist of granite, quartzite, and quartz that were brought by the glacier into the drainage basin of the enlarged Allegheny River from distant sources in Canada. The granite pebbles are considerably altered, the feldspars being mostly kaolinized as a result of longcontinued weathering. The age of these deposits, within the glacial epoch, has until recently been considered by Frank Leverett, who has made a regional study of this problem, ${ }^{15}$ to be at least as old as the Kansan. As stated above, however, Leverett now interprets them as having been deposited during the Illinoian stage of glaciation.

The probable existence of an oxbow curve, an abandoned meander in the Allegheny River, is indicated by the topography and by the presence of 'gravel in O'Hara Township west of Oakmont and Verona. There a curved flattish area about a quarter of a mile wide and 4 miles long, lying between contours 940 and 980 feet, is covered with clay in which a few rounded quartzite pebbles occur. It seems probable that when the river bed had become aggraded up to about 940 feet above sea level this curve afforded an outlet for part of the stream in which a backwash of river sediment was deposited. The meander was abandoned when the main channel of the river was cut deeper.

Wisconsin glacial deposits.-Comparatively few remains of the late glacial gravel of Wisconsin age are found in the New Kensington quadrangle. The generally steep-sided lower part of the valley affords few opportunities for preserving the deposit, and as the river cut its way through the late glacial valley fill most of the gravel was carried off. Some remains of gravel are preserved along the hillsides where the slope is only moderate, as at Oakmont and New Kensington. A remnant of late glacial gravel forms the small terrace on the north side of the river at River Valley, 1 mile north of Oakmont.

Borings for bridge foundations in the valley of the Allegheny River show that bedrock beneath water level, marking the old graded river bed that existed prior to the laying down of the late Pleistocene deposits, lies between 40 and 55 feet beneath the present river bed. The sand and gravel deposit beneath the present stream constitutes the earlier part of the late glacial deposits.

1s Leverett, Frank, Glacial formations and drainage features of the Erie and Ohio Basins: U. S. Geol. Survey Mon. 41, pp. 239 et seq., 1902. 
Alluvium.-The lowest terrace, on which are the main railroads and the lower parts of the river towns, is floored with alluviumgravel, sand, and clay-deposited during Recent stages of high water. The materials consist of reworked glacial deposits of both earlier and later age and of rock débris of local origin.

\section{STRUCTURE}

\section{SURFACE AND NEAR-SURFACE ROCKS}

General features.-The New Kensington quadrangle is situated in the north-central part of the Pittsburgh-Huntington Basin. 'See pl. 3.) The axis of the lowest part of the basin passes through this quadrangle, in which the attitude of the rocks conforms with the general structure of the region. The quadrangle is crossed by two anticlines and two synclines, the axes of which trend in general northeastward and pitch southwestward. In conformity also with the regional structure these subordinate folds that are developed on the flanks of the Pittsburgh-Huntington Basin have axes that curve in a horizontal plane and undulate in a vertical plane, and knobs and depressions are developed along the axes. The folds are very gentle, the steepest dips in the quadrangle are less than 200 feet to a mile, and over considerable areas the dip is less than 20 feet to a mile. In the northwestern part of the quadrangle the northeastward strike gives way to an eastward strike and the dips are southward, in accord with the regional structure. The relation of the structure of the rocks in this area to the geologic structure in other parts of southwestern Pennsylvania is shown in Plate 7.

The structure of the surface and near-surface rocks of the New Kensington quadrangle is shown on Plate 2 by means of contours drawn at intervals of 20 feet, based on the Upper Freeport coal. For use in field work the topographic base map was enlarged to the scale of 2 inches to the mile, and the key beds on which the contours are based, chiefly the Upper Freeport coal and the Ames limestone and locally the Cambridge ("Pine Creek") and Brush Creek limestones, were traced along the hillsides. The altitudes of outcropping key beds were obtained by a telescopic alidade and plane table survey. In addition, underground altitudes on the Upper Freeport coal were obtained from maps of the large coal mines in the quadrangle, supplemented by the records of several score diamonddrill holes that were put down to test the occurrence of coal in unmined areas. Although contours afford the most accurate and comprehensive means of portraying structure on a map, it is evident that the accuracy with which they show the structure depends on the number and areal distribution of points at a given horizon whose altitudes are determined. In those parts of the quadrangle where 
data are scarce the contours necessarily are more generalized than in the areas in which information is abundant.

In the New Kensington quadrangle the structure contours show that the surface and near-surface rocks are gently warped into broad undulating folds-the Kellersburg and Amity anticlines and the McMurray and Bradys Bend synclines.

McMurray syncline.-The McMurray syncline, which forms the local axis of the Pittsburgh-Huntington Basin, is the northeastward extension of the Nineveh syncline, from which it branches off in the Carnegie quadrangle, southwest of Pittsburgh. In the lowest point in this syncline, near the southwest corner of Pennsylvania, which is one of the lowest points in the basin, the Pittsburgh coal is deeply covered by overlying rocks and lies at an altitude of only 100 feet above sea level. From this low point the rocks rise northeastward along the axis of the basin, and near the southern border of the New Kensington quadrangle, a mile east of Etna, near the axis of the McMurray syncline, the Pittsburgh coal crops out near the crest of a hill at an altitude of 1,180 feet above the sea. There the Upper Freeport coal lies below the surface at an altitude of 540 feet above sea level. From this point the axis of the McMurray syncline extends northeastward, crosses Rich Hill, where the Pittsburgh coal crops out on several hilltops, and crosses Bull Creek just below Millerstown, and $3 \frac{1}{2}$ miles beyond Bull Creek this syncline passes into the Freeport quadrangle. In its course through the New Kensington quadrangle in a distance of 16 miles the axis of the McMurray syncline rises 300 feet.

Amity anticline.-The Amity anticline, which lies immediately southeast of the McMurray syncline and is named from the town of Amity, in Washington County, has been traced by M. E. Johnson, of the Pennsylvania Geological Survey, across the Pittsburgh quadrangle. The axis of this fold enters the New Kensington quadrangle at the town of Verona and leaves it 2 miles north of Tarentum. South of the Allegheny River the Amity anticline is marked by a broad knob, on which the horizon of the Upper Freeport coal has an altitude of 660 feet. Immediately north of the river a shallow saddle marks the axis of this fold, northeast of which the Amity anticline is characterized by a sharp nose, culminating in a small knob $1 \frac{1 / 2}{2}$ miles north of Tarentum, where the altitude of the Upper Freeport coal is 920 feet. Along the nose the strata rise 260 feet along the axis in 4 miles. This part of the Amity anticline marks the Bull Creek gas field.

Kellersburg anticline.-The Kellersburg anticline has been traced through the Clarion, Rural Valley, Kittanning, and Butler quadrangles, where it is a strongly developed fold along the crest of which much natural gas has accumulated. This fold enters the New 
Kensington quadrangle $1 \frac{1}{2}$ miles west of the northeast corner and extends southwestward across the entire area. The axis of the Kellersburg anticline plunges steeply to the southwest, causing the Upper Freeport coal to descend from an altitude of 1,140 feet at the northern border of the quadrangle to 840 feet in West Deer Township, a drop of 300 feet along the axis in a distance of $10 \frac{1}{2}$ miles. A natural-gas field, now considerably depleted, is located along this anticline in the northern part of the quadrangle.

A saddle across the axis interrupts the continuity of the Kellersburg anticline, south of which the axis is shifted a mile to the west. A knob is developed along the axis of the anticline, centering midway between Wildwood and Dorseyville. South of this knob the axis of the Kellersburg anticline again plunges southwestward and the Upper Freeport coal descends along the axis from an altitude of 940 feet to 700 feet in a distance of $6 \frac{1}{2}$ miles. The steepest dips in the quadrangle are in Indiana Township, where the rocks descend 340 feet in 3 miles from the knob on the Kellersburg anticline to a low point in the McMurray syncline.

Bradys Bend syncline.-The Kellersburg anticline is the westernmost of the well-developed northeastward-trending folds in this latitude in Pennsylvania. Farther west the folds are more irregular and less pronounced. On the western flank of the Kellersburg anticline the rocks descend to a comparatively shallow trough that marks the south end of the Bradys Bend syncline, which has been traced from the New Kensington quadrangle across the Butler quadrangle to the type locality in the Kittanning quadrangle. The axis of the Bradys Bend syncline enters the New Kensington quadrangle in eastern Penn Township, Butler County, where the altitude of the Upper Freeport coal is 980 feet, and extends southward across the eastern part of Middlesex Township. In the northwestern part of West Deer Township the axis of this syncline turns abruptly westward across Richland Township, in the southwest corner of which the axis again trends southward, and at the point where it leaves the quadrangle the altitude of the Upper Freeport coal is 720 feet. The western limb of the Bradys Bend syncline, in the area here considered, is marked by a westward-trending strike and a low southerly dip of the rocks.

Faults near Bakerstown station.-Faults, although not uncommon in parts of the plateau province adjacent to the Allegheny Front, are of rare occurrence in the interior of the province. A small zone of dislocation, however, is developed in the New Kensington quadrangle, in the cut of the Baltimore \& Ohio Railroad a few hundred feet north of Bakerstown station, Richland Township. The dislocations are exposed only in the railroad cut and are of such small extent that they are not shown on the map. 
The exposed rocks are lenticular beds of sandstone, shale, and coal, occurring near the middle of the Conemaugh formation. In the upper part of the railroad cut the strata lie almost flat, but in the lower part of the cut, just above the railroad tracks, the beds dip southward at angles locally as steep as $45^{\circ}$. At the north end of the cut the fault plane dips northward at an angle of about $45^{\circ}$ and the dislocation of the beds in the steep face of the cut is estimated to be about 40 feet. Apparently there was local tilting, faulting, and erosion of the lower beds before the deposition of the overlying strata.

\section{DEEP-L YING ROCKS}

Sketch contours based on the top of the Hundred-foot sand, in those parts of the quadrangle where well records are available, are fairly accordant with the contours based on the Upper Freeport coal. The two sets of contours show that the folds in the surface and near-surface rocks of Pennsylvanian age are also developed in the Mississippian and uppermost Devonian beds, notwithstanding the intervening unconformity, but from the information available the detailed structure of the oil and gas sands for any considerable area in the New Kensington quadrangle can not be determined.

The structure of the very deep-lying beds, such as the Oriskany group and the Tuscarora quartzite, which are likely to be tested for oil and gas, is not indicated by the structure of the outcropping beds because of the eastward thickening of the rocks. For instance, between the Geary well (Peoples Gas Co. well No. 770), 15 miles west of Pittsburgh, and the Booth \& Flinn well (Peoples Gas Co. well No. 1588), 4 miles northwest of Ligonier, a distance of about 50 miles, a bed of sandstone that lies approximately at the Oriskany horizon descends eastward about 800 feet, whereas between these two wells the Pittsburgh coal rises eastward about 1,500 feet.

\section{COAL}

\section{HISTORICAL SKETCH}

The New Kensington quadrangle is in the north-central part of the northern Appalachian bituminous coal region. (See fig. 5.) It lies just north of the main area of the Pittsburgh coal bed, only a few small outliers of which remain in the area here described as erosion remnants. This quadrangle is, however, underlain by the Upper Freeport coal, which is unusually thick and is extensively mined. Another bed of coal, the Bakerstown, which lies between the Upper Freeport and Pittsburgh beds but which is of comparatively little value, is mined locally. The coal beds below the Upper Freeport have not yet been thoroughly tested. 
The Upper Freeport coal is reported to have been first mined commercially in the New Kensington quadrangle about 1830, near the mouth of Bailey Run, for use in boiling brine in making salt. ${ }^{16}$ The brine was obtained from sandstone of the Pottsville formation, 400 feet below the Upper .Freeport coal. ${ }^{17}$ Other small mines were opened up about that time in this general vicinity. Between 1850 and 1860 a mine was operated below the mouth of Bailey Run, from which coal was shipped on the Pennsylvania Canal and later on the West Penn Railroad.

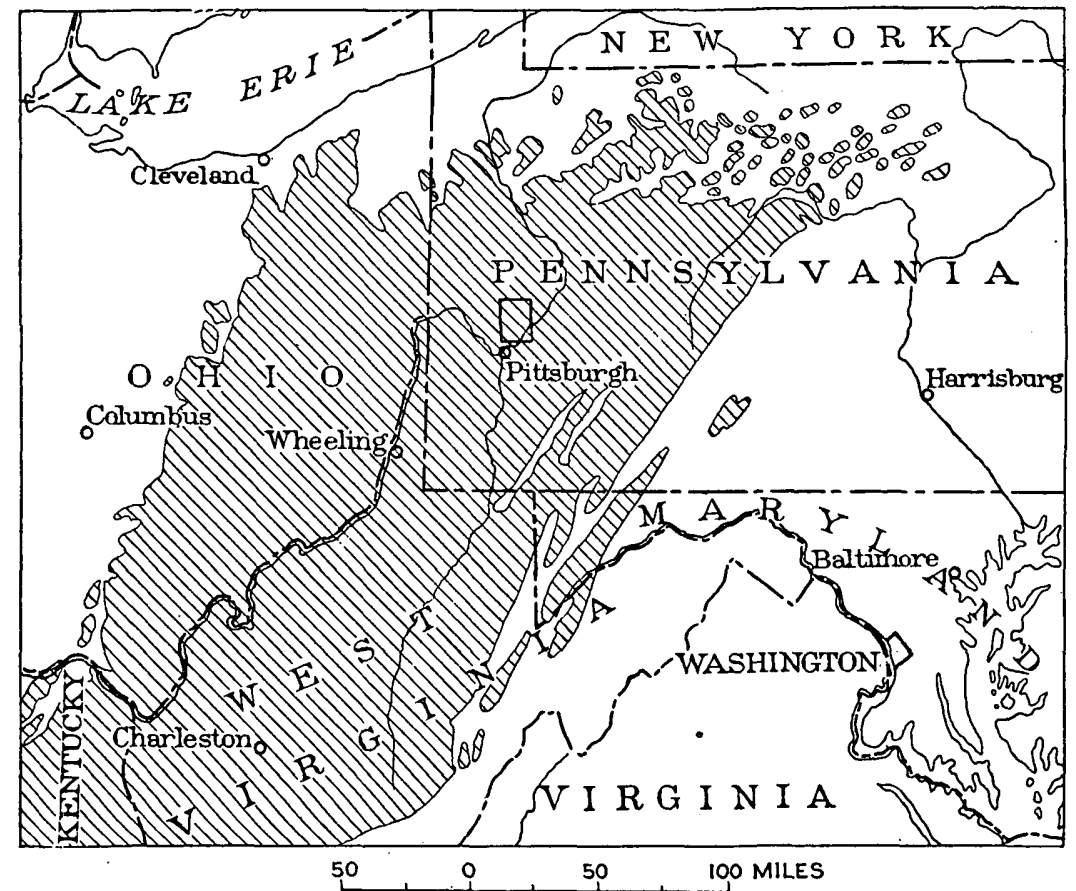

FIGURE 5.-Map of northern Appalachian bituminous coal region. The rectangular outline shows the position of the New Kensington quadrangle

At the time of the examination of this area by the Second Geological Survey of Pennsylvania, in 1876, a number of small country banks on the outcrops of the Pittsburgh, Bakerstown, and Upper Freeport coal beds were in operation. But for many years ${ }^{18}$ the only operating mine of any considerable capacity in this area was the one at the mouth of Bailey Run, worked by McFetridge Bros. (No. 9). ${ }^{19}$ Production statistics for this mine are available since 1890, in which

${ }^{16}$ Rayburn, J. M., The deposit of double-thick Upper Freeport coal situated in the valley of the Allegheny River in Allegheny, Butler, and Westmoreland Counties, Pa.: Eng. Soc. Western Pennsylvania Proc., vol. 40, p. 28, 1924.

${ }_{17}$ White, I. C., Report of progress in the Beaver River district: Pennsylvania Second Geol. Survey Rept. Q, p. 147, 1878.

18 Rayburn, J. M., op. cit., p. 28.

${ }^{10}$ Numbers after the names of coal mines refer to their location on the economic-geology map (pl. 2). 
year the McFetridge mine is credited, by the Pennsylvania Department of Mines, with an output of 17,324 tons.

Intensive development of the thick Upper Freeport coal area dates from about 1900. The Cornell mine (No. 8) and the Creighton mine (No. 12), in East Deer Township, the Harwick mine (No. 6), in Springdale Township, and the No. 1 Bessemer mine (No. 15), in West Deer Township, Allegheny County, and the No. 1 Valley Camp mine (No. 10), in Lower Burrell Township, Westmoreland County, were in operation between 1901 and 1903. After that development was rapid. During the last year of the World War the coal mines of the New Kensington quadrangle produced 4,375,574 short tons.

The stratigraphic occurrence of the beds of coal and the intervals between them are outlined in the description of the formations and are illustrated in the columnar section (pl. 4) and in the platted records of diamond drilling (pl. 5). The structure contours on the structure and economic geology map (pl. 2), showing the dip of the coal beds and the location of the axes of folding, afford information that is helpful in the location of shafts and mine workings in relation to economic haulage and drainage.

The approximate depth of the horizon of the Upper Freeport coal beneath the surface at any locality in the quadrangle can be obtained from the map by subtracting from the altitude of the surface at the locality selected (indicated by the topographic contours, shown by brown lines) the altitude of the Upper Freeport coal (indicated by the structure contours, shown by red lines). Thus, the approximate depth of the Upper Freeport coal beneath the surface at the road crossing 1 mile north of Acmetonia is 349 feet (969 feet, surface altitude, minus 620 feet).

The names and locations of coal mines and the locations of country banks in the New Kensington quadrangle are shown on the economicgeology map (pl. 2), and certain details of the occurrence, thickness, and character of the coal beds are givenn below.

\section{UPPER FREEPORT COAL}

In the New Kensington quadrangle the Upper Freeport coal crops out in several small areas, and its horizon underlies the remaining part of the quadrangle at depths beneath the surface indicated by the contour lines on the structure map.

The Upper Freeport coal bed crops out in the valley of the Allegheny River and its tributaries-Bull Creek and Wilson and Bailey Runs-in the vicinity of Tarentum. It is also exposed where several streams have cut down to its horizon along or adjacent to the axis of the Kellersburg anticline in Coal Hollow along Sarver Run, in the valleys of several headwater tributaries to Bull Creek, and 
in the valley of Pine Creek above Glenshaw. The Upper Freeport coal also crops out in the valley of Glade Run in the northwest corner of the quadrangle. (See p. 39.)

In this quadrangle the Upper Freeport coal varies considerably in thickness. Locally it is almost 10 feet thick, it averages more than 7 feet over a large area, and in places it disappears. The Upper Freeport coal is reported absent in a few drill holes west of the Allegheny River in the vicinity of Glenover, and the coal is also locally missing in the valley of Pine Creek above Elfinwild.

The approximate area in which the Upper Freeport coal attains such increased thickness that it is known as the thick Upper Freeport bed is shown in Figure 4. The boundary of the area is subject to revision, as a result of future mining operations and of more core drilling. The map indicates that about 88 square miles of the New Kensington quadrangle is underlain by the thick Upper Freeport coal.

The thick Upper Freeport coal bed is rather uniform over large areas, although mining operations have indicated that the coal is locally absent in "so-called "faults" or barren areas. The coal is underlain by soft gray clay that ranges in thickness from a few inches to 3 or 4 feet. The lower 8 to 12 inches of the bed consists of layers of coal separated by thin partings of clay and shale, above which is the main lower bench, consisting of 30 to 40 inches of clean coal, which is the most valuable part of the bed. Bony coal high in ash, several inches to a foot in thickness; separates the lower bench from the upper bench, which consists of 32 to 34 inches of coal that contains somewhat more ash than the lower bench. The roof is variable. Over part of the area, estimated by Rayburn to be about 20 per cent, the thick Upper Freeport coal is overlain by carbonaceous shale, which in places grades into canneloid shale or cannel coal high in ash, ranging from a few inches to 3 or 4 feet in thickness. Elsewhere the coal is overlain by gray sandy shale. (See fig. 6.)

In mining the general practice is to remove the upper and lower benches and the intervening bony coal and to leave the lowermost few inches of thin coal and partings as the floor and the cannel coal and shale as the roof. The bony coal, which is high in ash, is discarded.

The thick Upper Freeport coal has been examined microscopically by Thiessen,${ }^{20}$ who reports that the bed differs in composition vertically. The lower bench consists chiefly of bands of "bright coal" interbedded with subordinate "dull coal," and the upper bench consists of more "dull coal" and relatively less "bright coal." At the top of the bed the cannel coal contains comparatively little bright coal.

${ }^{20}$ Thiessen, Reinhardt, A microscopic study of the Freeport coal bed, Pennsylvania: Carnegie Inst. Technology Bull. 2, 1922. 


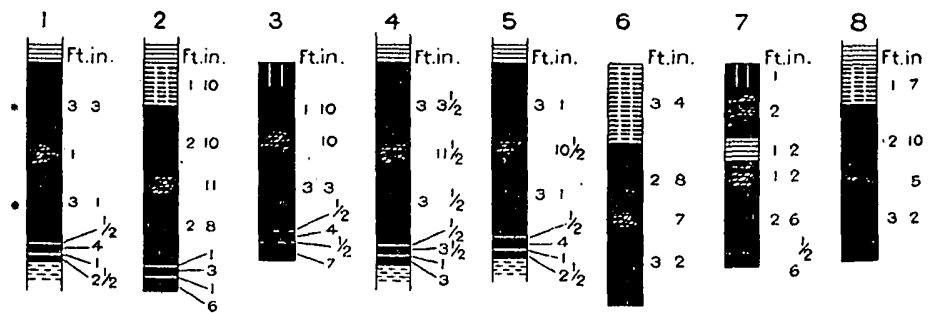

- Samples analyzed. and 8311.9
and
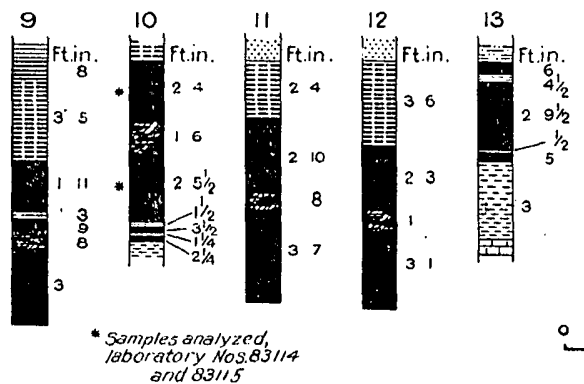

14

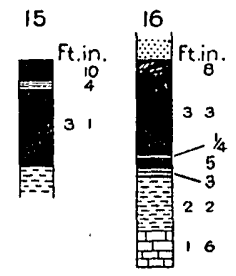
and 83115
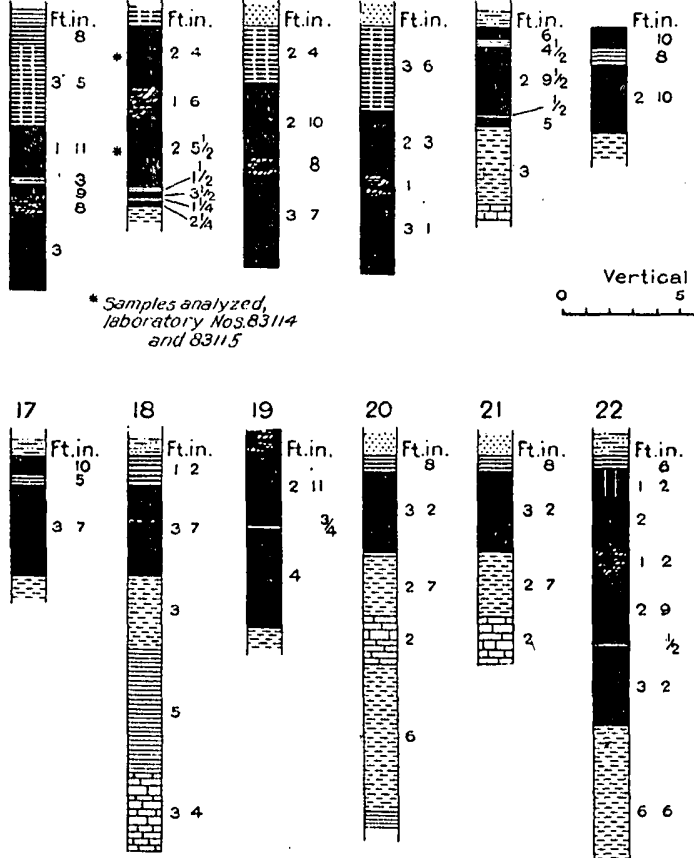

10 Feet

\section{EXPLANATION}
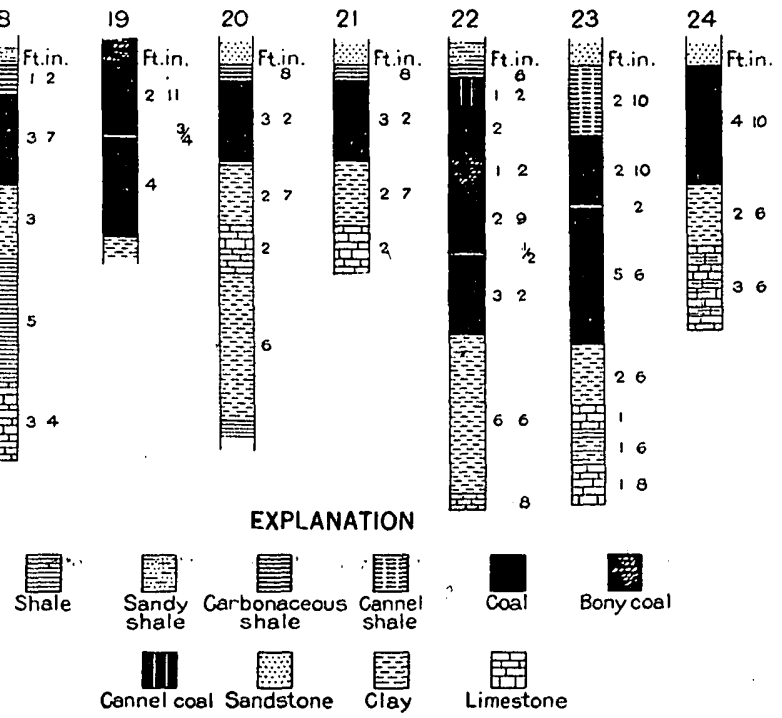

Fiaure 6.-Sections of Upper Freeport coal in the New Kensington quadrangle
1. New Field No. 1
2. Oakmont
3. Springdale
4. Harmar
5. Indianola
6. Creighton
7. Peterson
8. Bessemer No. 2
9. Superior No. 1
10. Benjamin
11. Berry
12. Francis
13. Joe Reith
14. Mar
15. Sun
16. Dawson
17. Settlemeyer
18. McDowell Run

19. W. H. Porter

20. Railroad cut at Mount Royal

21. Elfinwild

22. Junction of Bailey and Watson Runs

23. East of tipple of Valley Camp mine

24. 500 feet east of section 23 
According to Thiessen, the "bright coal," called "anthraxylon," is that part of the coal which is derived from the woody or cellulosic constituents of plants, such as fragments of stems, branches, twigs, and roots. The "dull coal," called " attritus," consists of various plant products, such as spores, cuticles, resinous matter, waxes, and gums. The cannel coal consists largely of spore matter; it contains much humic but very little woody material.

The question has been raised whether the thick Upper Freeport coal represents the union of the Upper and Lower Freeport coal beds, which, in the vicinity of Freeport, Pa., are separated by about 50 feet of intervening sandstone and shale. Consideration of the facts, however, shows that the two beds do not coalesce. Throughout the area in the New. Kensington quadrangle occupied by the thick Upper Freeport coal, wherever tested, the coal lies on a bed of soft underclay, which overlies the Upper Freeport limestone. The coal bed has been traced eastward in the valley of the Allegheny River, and its identity has been established with the Upper Freeport bed in the type area. The local thickening of the bed occurs in its upper part, indicating that coal-making conditions continued longer in the area occupied by the thick Upper Freeport coal than elsewhere. Drill holes put down through the thick Upper Freeport coal show the presence of the Lower Freeport coal at its-normal horizon, between 40 and 60 feet below.

The following sections were measured in areas where the Upper Freeport coal crops out. (See pl. 2.)

In Coal Hollow, Buffalo Township, Butler County, the Upper Freeport coal is exposed in a narrow strip about three-quarters of a mile long, near water level in Sarver Run. Small country banks in this area have been opened for many years, and the following section is typical:

Section of Upper Freeport coal in old Joe Reith mine, in Coal Hollow

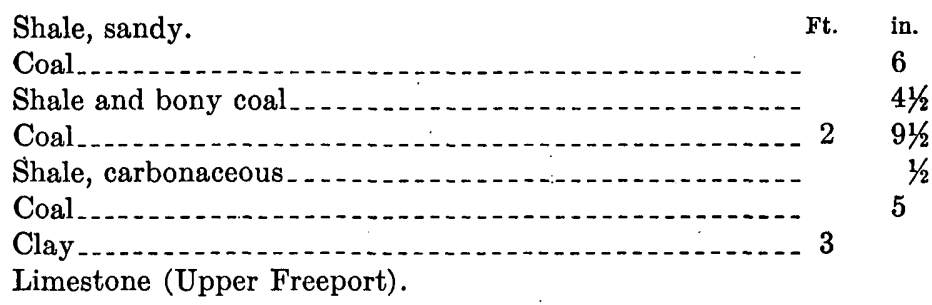

The Upper Freeport coal crops out for a distance of $2 \frac{1}{2}$ miles below Lardintown in Clinton Township, in the valley of a branch of Bull Creek, and several country banks have been opened in this area, as shown on the map. Near one of these openings the following section was measured: 
Section of Upper Freeport coal and associated beds near Lardintown

Shale, sandy
Coal and carbonaceous.shale

The Upper Freeport coal crops out in the upper valley of Bull Creek in Clinton Township, Butler County, and in West Deer and Fawn Townships, Allegheny County, where it has been opened in several country banks and in two mines-the Mar mine of the North Butler Coal Co. and the Sun mine of the Sun Coal Co.-from which coal is shipped over the Bessemer \& Lake Erie Railroad.

The following section in the Mar mine, near the northern part of this area, is reported by J. D. Sisler, of the Topographic and Geologic Survey of Pennsylvania. ${ }^{21}$

Section of Upper Freeport coal in Mar mine, Clinton Township, Butler County

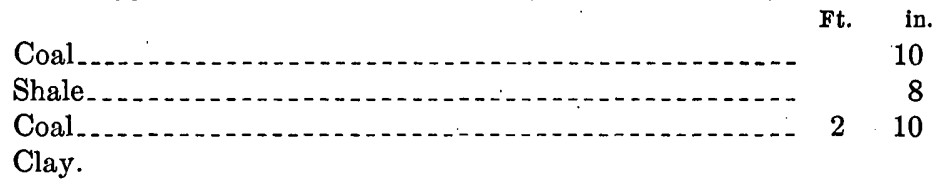

Near the middle of this area is the Sun mine, of which the following section is reported by Sisler:

Section of Upper Freeport coal in Sun mine, Clinton Township, Butler County

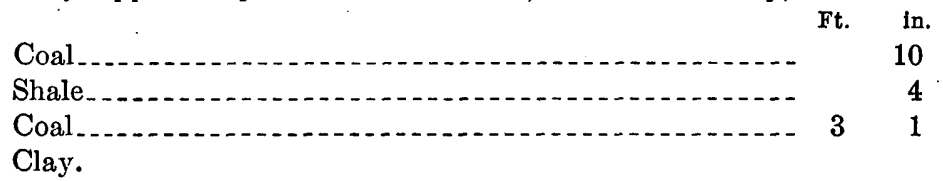

Near the southern part of this area, half a mile south of Cunningham, the following section was measured by the writer:

Section of Upper Freeport coal at Dawson country bank, West Deer Township, Allegheny County

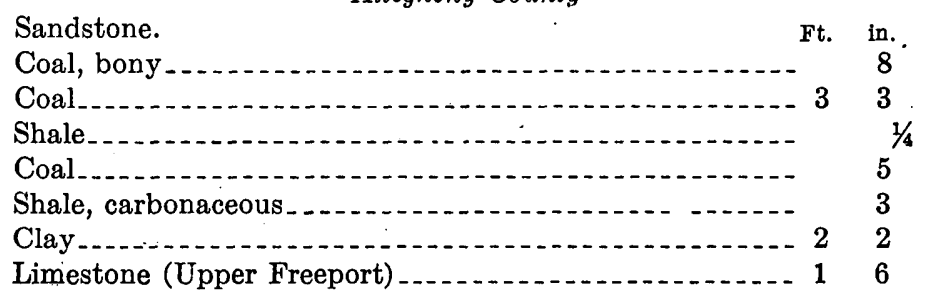

" Sislar, J. D., Bituminous coal flelds of Pennsylvania, pt. 2, p. 93, 1926. 
Near the western part of this area, 11/2 miles west of Cunningham, the following section was measured by the writer:

Section of Upper Freeport coal at Settlemeyer country bank, Clinton Township, Butler County

Shale, sandy.

Ft. in.

Coal

Shale, carbonaceous $\ldots . . .65$

Coal._...

Clay.

In the lower valley of Bull Creek the Upper Freeport coal is exposed for a distance of 3 miles above Tarentum, and in this area there are several country banks and one mine with railroad connections. Part of the workings of the Avenue mine of the Allegheny Coal \& Coke Co. at Brackenridge, in the Freeport quadrangle, extend into the Bull Creek area of the New Kensington quadrangle, and the creek is crossed a mile above Tarentum by a viaduct that connects parts of the mine on both sides of the valley.

On McDowell Run, half a mile above its mouth, the following section is exposed:

Section of Upper Freeport coal on McDowell Run, Fawn Township, Allegheny County

Sandy shale

Ft. in.

Shale carbonaceous (including bony coal at base) $-2 . .-10$

Coal bed (including partings)

Clay, gray ....... 3

Shale

Limestone (Upper Freeport) $\ldots \ldots \ldots$

Measurements of the coal bed in the lower valley of Bull Creek, in the Avenue mine and in several country banks-Van Thiel, Porter, Haas, and Fawn No. 2-show a bony-coal roof overlying the main bench, consisting of 34 to 37 inches of coal, below which is a 1-inch parting and a lower bench of coal 3 to 5 inches thick resting on a floor of clay.

The Upper Freeport coal is exposed near water level along both banks of the Allegheny River for a distance of about a mile below Tarentum. The dip causes the bed to pass beneath the surface on the south side of the river near Valley Camp and on the north side of the river near Hite, as shown on Plate 2. The outcrop of the coal also extends up Wilson and Bailey Runs a little more than a mile.

Throughout the rest of the quadrangle, except in the small areas in the valley of Pine Creek above Glenshaw and in the valley of Glade Run, in the northwest corner of the quadrangle, the horizon of the Upper Freeport coal is underground at different depths beneath the surface, which may be determined for any part of the area from the 
structure contours, as stated on page 33. Measurements of the Upper Freeport coal taken in the mines are given in Figure 6.

The Upper Freeport coal is reported to have been mined at Glenshaw about 1900 . Remains of the old workings indicative of rather extensive operations were to be seen in 1921, but the mine then was abandoned. At the time of the writer's examination of this area a small country bank was being operated by the W. H. Porter Coal Co. just north of Glenshaw, in Shaler Township, Allegheny County. The coal was reached by a shaft 30 feet deep.

Section of Upper Freeport coal in W. H. Porter mine, Glenshaw

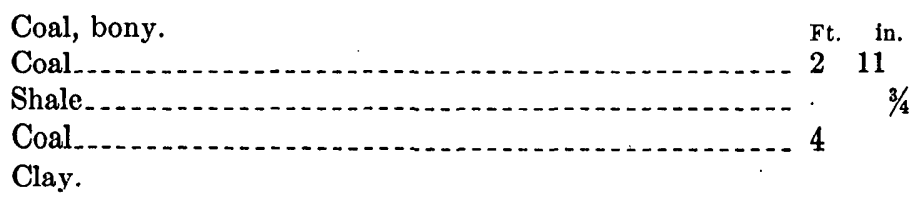

This section is typical of the coal as mined in several small country banks in the valley of Pine Creek between Mount Royal and Glenshaw. In the railroad cut at Mount Royal the following section is exposed:

Section of Upper Freeport coal in railroad out at Mount Royal, Shaler Township, Allegheny County

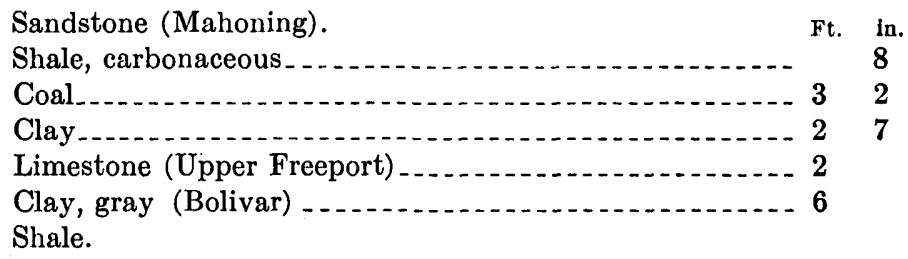

North of this place, within the area occupied by the outcrop of the Allegheny formation, the Upper Freeport coal thins out and locally disappears. In the vicinity of Wildwood, however, in the Wildwood mine (No. 22), which was opened after field work in this quadrangle was completed, the coal is present in thick beds.

In the valley of Glade Run in the northwest corner of the quadrangle the Upper Freeport coal is exposed for a distance of about 2 miles. Three small abandoned country banks were mapped in this area. Where the coal was measured it was 20 to 22 inches thick. The roof in the openings is sandy shale, and the floor is clay.

The principal mines in the New Kensington quadrangle that operate on the thick Upper Freeport coal are listed below. With the exception of four drift or slope mines that are located on the outcrop, they are all shaft mines. 
Mines in New Kensington quadrangle operating on the thick Upper Freeport coal bed

\begin{tabular}{|c|c|c|c|c|}
\hline $\begin{array}{c}\text { No. } \\
\text { on } \\
\text { pl. } 2\end{array}$ & Name of mine & Location & Opening & Name of company \\
\hline $\begin{array}{r}4 \\
5 \\
6 \\
8 \\
9 \\
10 \\
12 \\
14 \\
15 \\
16 \\
17 \\
18 \\
19\end{array}$ & 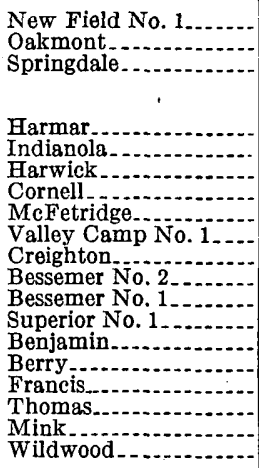 & 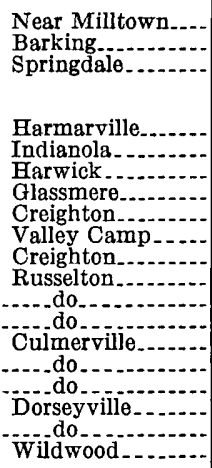 & 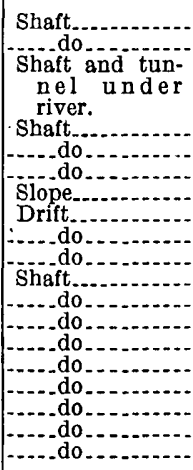 & $\begin{array}{l}\text { New Field By-Products Coal Co. } \\
\text { Hillman Coal \& Coke Co. } \\
\text { Allegheny-Pittsburgh Coal Co. } \\
\\
\text { Consumers Mining Co. } \\
\text { Inland Collieries Cc. } \\
\text { Harwick Coal Co. } \\
\text { Crucible Fuel Co. } \\
\text { McFetridge Bros. Coal Co. } \\
\text { Valley Camp Coal Co. } \\
\text { Pittsburgh Plate Glass Co. } \\
\text { Republic Iron \& Steel Co. } \\
\text { Do. } \\
\text { Superior Fuel Co. } \\
\text { Ford Collieries Co. } \\
\text { Do. } \\
\text { Do. } \\
\text { John G. Bart, agent. } \\
\text { Harrison \& Quinette. } \\
\text { Butler Consolidated Coal Co. }\end{array}$ \\
\hline
\end{tabular}

The location of these mines, the depth of the coal beneath the surface, and the dip of the beds are shown on Plate 2. Typical measurements of the coal bed are given in Figure 6, and analyses of the coal are given on pages $44-45$.

\section{BAKERSTOWN COAL}

The Bakerstown coal was named in 1878 by I. C. White ${ }^{22}$ from Bakerstown, Richland Township, Allegheny County, where the bed lies about 90 feet below the Ames limestone. This coal is characteristically lenticular and irregular in its occurrence. In the general vicinity of Bakerstown the bed includes several layers of shale.

At the time when the quadrangle was examined for the present. report only two country banks were being operated on the Bakerstown coal-one in Richland Township, Allegheny County, and the other in Adams Township, Butler County. Remains of several abandoned openings on this bed were observed in the general vicinity of the type locality of the coal in the northwestern part of the quadrangle, but elsewhere in the quadrangle this bed apparently is poorly developed. Very few "blossoms" of the Bakerstown coal were observed along the roadsides.

In a small country bank located in a gully along the road close to the western border of the quadrangle, $13 / 4$ miles northwest of Valencia, in Adams Township; Butler County, the following section was measured:

22 White, I. O., Report of progress in the Beaver River district, Pennsylvania Second Geol. Surrey Rept. Q, p. 162, 1878. 
Section of Bakerstown coal 13/4 miles northwest of Valencia

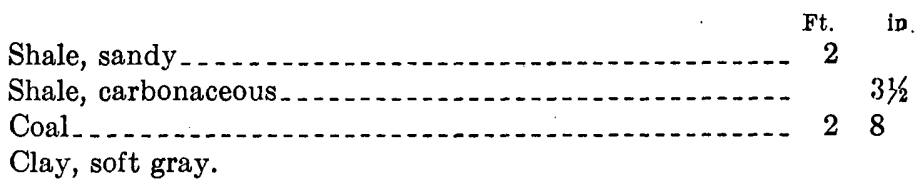

In the Fisher country bank, just east of the Butler plank road 1 mile south of Bakerstown, the following section was measured and the upper bench of coal was sampled for analysis. (See p. 45.)

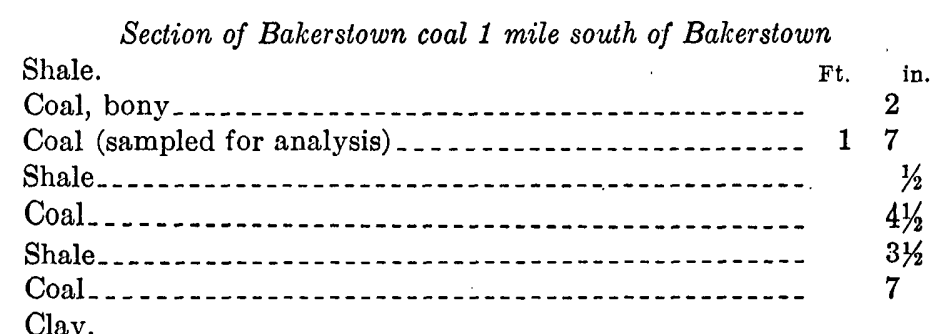

PITTSBURGH COAL

Erosion remnants of the Pittsburgh coal cap a number of hilltops in the New Kensington quadrangle, as shown on Plate 2. At one time or another, dating back to the time when the country was first settled, the Pittsburgh coal has been opened and mined on every hilltop where it occurs within the quadrangle, and the small original reserves have been in large part exhausted.

When the quadrangle was examined by the writer only a few country banks, the location of which is shown on the economicgeology map, were in operation on the Pittsburgh coal. Most of them are on the series of knobs known as Rich Hill, in Indiana Township, Allegheny County. The largest body of Pittsburgh coal in the quadrangle is in the hill 1 mile south of Logans Ferry, in Plum Township, Allegheny County. In none of these openings was the entire thickness of the bed exposed. The greatest thickness measured was $44 \%$ inches of coal in the mine three-fourths mile southeast of Logans Ferry. The coal bed is reported to be locally 8 feet 6 inches thick.

\section{COAL BELOW THE UPPER FREEPORT}

Very little information is available concerning the coal beds below the Upper Freeport in the New Kensington quadrangle. These beds are not exposed in this area, and because of the great value and widespread distribution of the Upper Freeport coal the lower coals have not yet been thoroughly tested. The records of the few diamond-drill holes that have been put down below the Upper Freeport coal, examined by the writer, show the local presence of thin, variable 
beds of coal in the general position of the Lower Freeport, Upper, Middle, and Lower Kittanning, Clarion, and Brookville beds, but no one section shows the presence of coal at all these horizons. The locations and details of the drilling can not be published. A bed of coal in the approximate position of the Lower Kittanning, lying between 168 and 203 feet below the Upper Freeport, seems to be the most persistent. So far as the writer is aware, it has not been determined whether any bed of coal in this quadrangle below the Upper Freeport is of workable extent and thickness under present conditions. More drilling must be done in this area to establish the value of these lower coal beds.

\section{Chemical ChaRACTER AND USE}

The analyses of mine samples of the Upper Freeport coal from the New Kensington quadrangle, given on pages 44-45, show its chemical character. The samples were collected in the mines by representatives of the United States Geological Survey or the United States Bureau of Mines, in accordance with the standard method of sampling, by making a cut from the roof to the floor across a fresh face of the bed and rejecting the partings discarded in mining. After the samples were pulverized and quartered down they were sealed in a galvanized can and sent to the laboratory of the United States Bureau of Mines, where they were analyzed under uniform standard conditions.

A proximate analysis, showing the percentage of moisture, volatile matter, fixed carbon, and ash was made of all the samples. The heating value of each sample, expressed in British thermal units, was also determined. An ultimate analysis, showing the percentage of carbon, oxygen, hydrogen, nitrogen, and sulphur, was made of some samples. As indicated, some of the samples represented only the lower coal bench of the Upper Freeport bed, others the upper bench, and others the cannel shale or coal. Only two analyses are available of the bony coal that separates the upper and lower benches.

The results of the analyses are given in three forms: Form A shows the composition of the sample as received at the laboratory and represents the condition of the coal in the mine at the time of sampling. Form B shows the composition of the coal calculated as theoretically free from moisture. Form $\mathrm{C}$ shows the composition of the coal calculated as theoretically free from moisture and ash. Forms B and $\mathrm{C}$ do not indicate the composition of the coal as commercially mined and marketed.

The analyses show that the Upper Freeport bed in the New Kensington quadrangle is a high-volatile bituminous coal, having a fuel ratio (fixed carbon divided by volatile matter) of about 1.5 and a fixed carbon content on a moisture and ash free basis of about 61 per cent. 
The coal is low in moisture and moderately low in sulphur, and the main benches are moderately low in ash.

A typical sample "as received" has approximately the following composition expressed in percentages:

Moisture

Volatile matter

Fixed carbon

Ash

This coal is extensively used for making steam and is highly valued. Two large power plants operating on coal from the New Kensington quadrangle are located in this area. The Springdale plant of the West Penn system uses coal from the Springdale mine, and the Colfax plant of the Duquesne Light Co. at Cheswick, uses coal from the Harwick mine. 


\begin{tabular}{|c|c|c|c|c|c|c|c|c|c|c|c|}
\hline & & 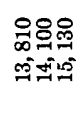 & 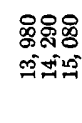 & 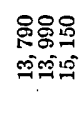 & 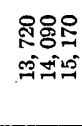 & 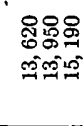 & 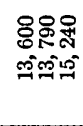 & 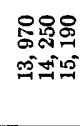 & 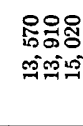 & 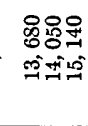 & 39 \\
\hline & 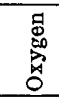 & & & & & & & & & $\begin{array}{lll}+\infty & 0.15 \\
\infty & 0.0\end{array}$ & $\begin{array}{l}90 \% \\
\text { Miso }\end{array}$ \\
\hline & 总范 & & & & & & & & & מor & 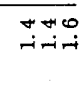 \\
\hline 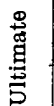 & 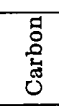 & & & & & & & & & 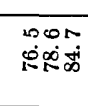 & $\begin{array}{l}\text { चर० } \\
\text { संखिए }\end{array}$ \\
\hline & 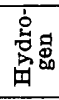 & & & & & & & & & 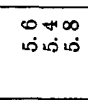 & Antr \\
\hline & 宽急 & rifo & 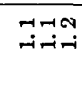 & मتन & 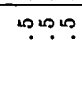 & 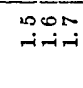 & $\begin{array}{l}\text { Nomb } \\
\text { Nicis }\end{array}$ & 909 & $\begin{array}{l}\text { minto } \\
\text { जicis }\end{array}$ & 어 & 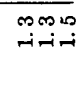 \\
\hline & 吾 & \begin{tabular}{l|l}
$0 \infty$ & \\
$\dot{0}$ &
\end{tabular} & $\begin{array}{l}7 \infty \\
1000\end{array}$ & ON & $\begin{array}{ll}9 \rightarrow 1 \\
0 \pi\end{array}$ & $\begin{array}{l}\text { ON } \\
\infty \infty \infty\end{array}$ & $\begin{array}{l}+120 \\
0.00\end{array}$ & OA- & $\stackrel{\infty}{=}$ & יָת & ro \\
\hline 造 & 路 & 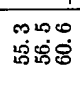 & 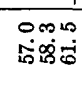 & 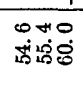 & ㅁ. & 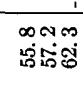 & 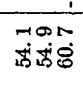 & 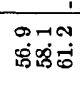 & 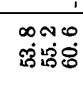 & 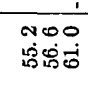 & $\begin{array}{l}\infty 00 \\
\text { is } \operatorname{sic}^{\circ} 8\end{array}$ \\
\hline 葛 & 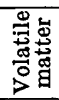 & 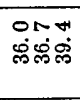 & 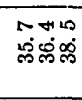 & 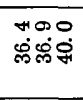 & 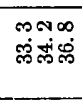 & 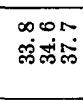 & 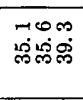 & 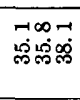 & 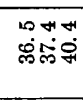 & 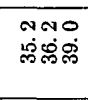 & 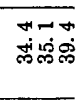 \\
\hline & 产是 & $\vec{i}$ & $\stackrel{\sim}{\sim}$ & 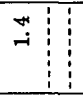 & $\hat{s}$ & $\ddot{i}$ & \begin{tabular}{l|l}
+4 & \\
-1 &
\end{tabular} & $\stackrel{\circ}{\sim}$ & $\stackrel{\leftrightarrow}{\sim}$ & \begin{tabular}{l|l}
0 & \\
$\stackrel{N}{*}$ &
\end{tabular} & $\vec{a}$ \\
\hline & & $4 M O$ & ४MO & $4 m 0$ & 490 & ४MO & 4חO & $4 M O$ & $4 m 0$ & বMO & ४MO \\
\hline & & $\stackrel{9}{0}$ & $\because$ & 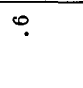 & $\stackrel{\circ}{-}$ & $\vec{i}$ & $\infty$. & $\circ$. & $\stackrel{H}{-}$ & $\stackrel{\circ}{-1}$ & $\infty$. \\
\hline & & 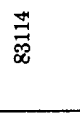 & $\stackrel{\mathscr{7}}{\mathscr{\varpi}}$ & $\overrightarrow{\widetilde{I}}$ & ๙્๊ & 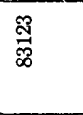 & $\stackrel{\infty}{\exists}$ & $\stackrel{8}{\exists}$ & $\underset{\mathscr{D}}{\mathbb{D}}$ & $\begin{array}{l}\mathfrak{N} \\
\substack{\infty \\
\infty \\
\infty}\end{array}$ & $\begin{array}{l}\text { 芯 } \\
\text { 商 }\end{array}$ \\
\hline & & 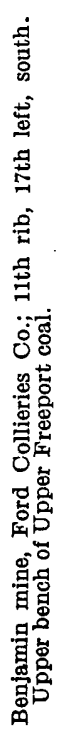 & 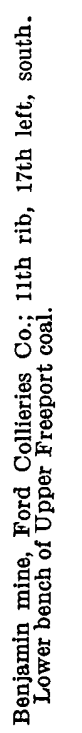 & 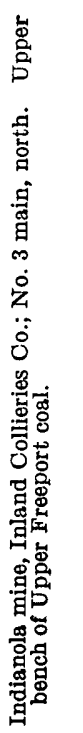 & 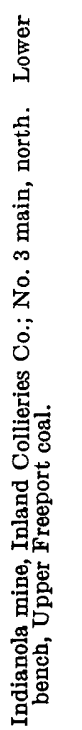 & 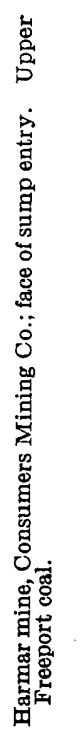 & 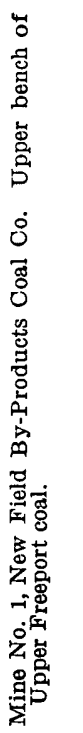 & 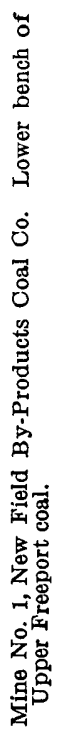 & 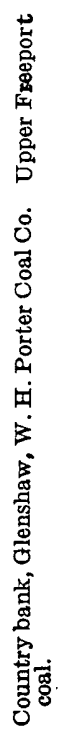 & 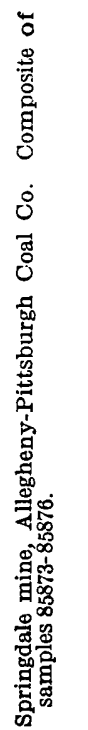 & 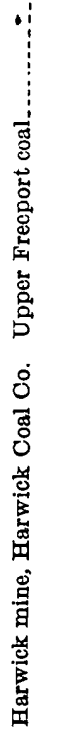 \\
\hline
\end{tabular}




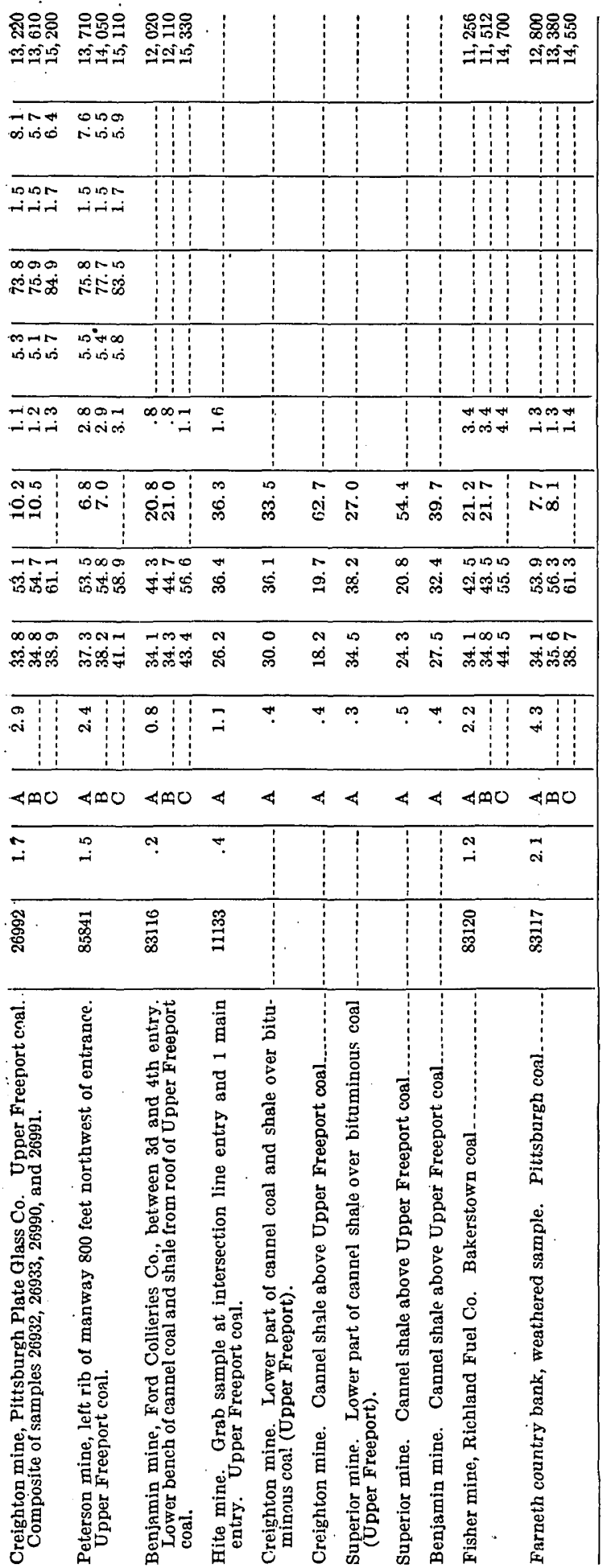




\section{PRODUCTION AND RESERVES}

Statistics of the production of coal by mines in the New Kensington quadrangle, for the period 1890-1926, given in the following table, were compiled from figures furnished by the Pennsylvania Department of Mines. The table shows that during this period more than $76,000,000$ tons of coal were produced in the quadrangle.

Coal produced in the New Kensington quadrangle, 1890-1926

[Figures furnished by Department of Mines, Commonwealth of Pennsylvania]

\begin{tabular}{|c|c|c|}
\hline Mine & Operator & Net tons \\
\hline 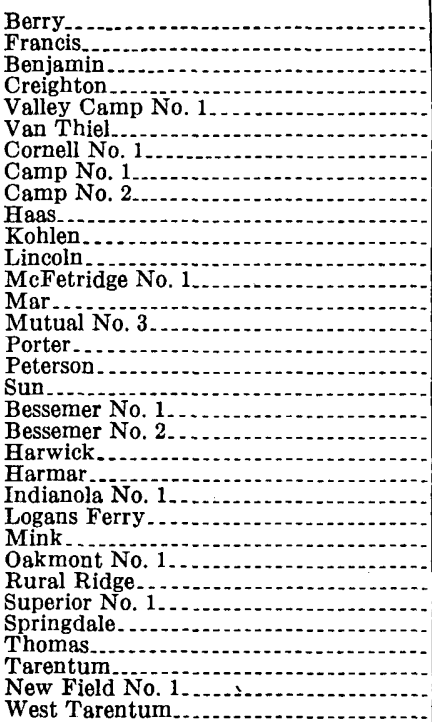 & 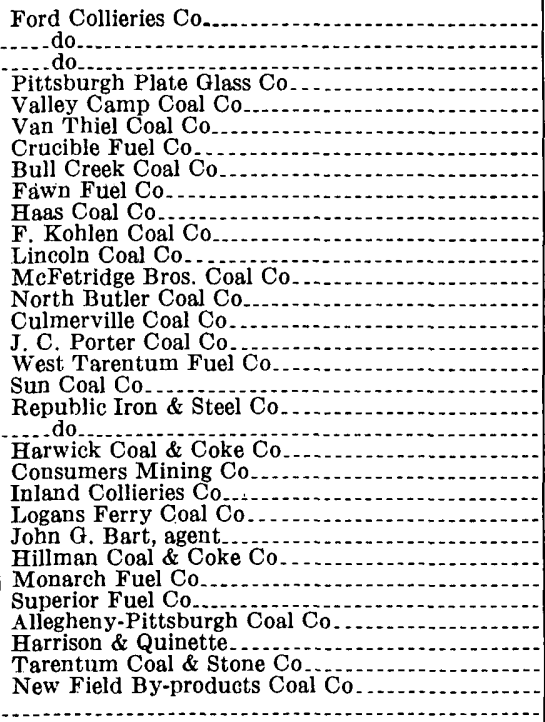 & $\begin{array}{r}5,232,897 \\
5,143,051 \\
5,513,839 \\
5,874,223 \\
6,825,496 \\
116,598 \\
5,049,603 \\
69,182 \\
52,346 \\
159,931 \\
1,600 \\
14,000 \\
4,592,978 \\
103,447 \\
76,201 \\
11,536 \\
1,224,023 \\
537,038 \\
7,975,136 \\
3,340,109 \\
8,631,021 \\
2,999,563 \\
2,909,504 \\
24,077 \\
15,000 \\
1,575,700 \\
1,631,057 \\
2,960,657 \\
2,062,164 \\
61,252 \\
101,071 \\
1,372,953 \\
76,353\end{array}$ \\
\hline & & $76,333,606$ \\
\hline
\end{tabular}

The reserves of thick Upper Freeport coal in the New Kensington quadrangle can not at present be accurately determined because of insufficient data; only a rough estimate can now be made. By assuming an average thickness of coal, minable under present conditions of operation, of 68 inches (composed of 33 inches in the upper bench and 35 inches in the lower bench) and an area of 88 square miles (indicated by fig. 4 but subject to revision) underlain by the thick bed, then on the basis of 1,800 short tons to the acre-foot and deducting the coal already mined, the indicated quantity of unmined coal is $500,000,000$ tons. This tonnage will be reduced by losses in mining.

In the part of the quadrangle that is not underlain by this thick bed the reserves of the Upper Freeport coal are still more doubtful, because the thickness of the bed is known in only a few localities and because of the presence of barren areas of unknown extent in which the coal is absent. These reserves may amount to $300,000,000$ tons. 


\section{OII FROM COAL AND SHALE}

The cannel shale at the top of the Upper Freeport coal bed is a possible source of oil obtainable by distillation. The following table, compiled from a report by Fettke, ${ }^{23}$ shows results of laboratory tests of several samples from mines in the New Kensington quadrangle.

Oil from cannel shale

\begin{tabular}{|c|c|c|c|c|c|}
\hline Source of sample & $\begin{array}{l}\text { Thick- } \\
\text { ness of } \\
\text { shale }\end{array}$ & $\begin{array}{l}\text { Oil per } \\
\text { ton of } \\
\text { shale }\end{array}$ & Source of sample & $\begin{array}{l}\text { Thick- } \\
\text { ness of } \\
\text { shale }\end{array}$ & $\begin{array}{l}\text { Oil per } \\
\text { ton of } \\
\text { shale }\end{array}$ \\
\hline $\begin{array}{l}\text { Oakmont mine No. 1... } \\
\text { Creighton mine........ } \\
\text { Bessemer mine No. 2... }\end{array}$ & 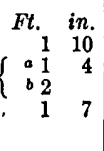 & $\begin{array}{r}\text { Gallons } \\
25.5 \\
29.6 \\
13.4 \\
26.4\end{array}$ & $\begin{array}{l}\text { Superior mine No. 1. } \\
\text { Benjamin mine } \\
\text { Francis mine..... } \\
\text { Berry mine.... }\end{array}$ & $\left\{\begin{array}{rr}F t . & i n . \\
c 1 & 2 \\
d 2 & 3 \\
2 & 3 \\
3 & 6 \\
2 & 4\end{array}\right.$ & $\begin{array}{r}\text { Gallons } \\
34.7 \\
17.6 \\
27.3 \\
31.4 \\
30.0\end{array}$ \\
\hline
\end{tabular}

a Lower part of bed 3 feet 4 inches thick.

$\checkmark$ Upper part of bed 3 feet 4 .inches thick:

c Lower part of bed 3 feet 5 inches thick.

$d$ Upper part of bed 3 feet 5 inches thick.

When it becomes economically possible to extract oil from oil shale and coal, although shale is an important reserve, coal will have certain advantages over shale. The residue from the distillation of coal is a valuable fuel, whereas spent shale is practically worthless. Moreover, recent experiments on the liquefaction and hydrogenation of coal indicate that the yield of oil from coal will be greater than that from shale. Some method of processing coal doubtless will eventually be practiced.

\section{OIL AND GAS}

\section{REVIEW OF THE NORTHERN APPALACHIAN REGION}

The New Kensington quadrangle forms part of the northern Appalachian oil and gas region, which occupies an area of elliptical outline extending northeastward across the Appalachian Plateaus, a distance of about 500 miles. The region includes many fields in southeastern Ontario, New York, Pennsylvania, West Virginia, eastern Kentucky, and central and eastern Ohio. In its broadest part, across the panhandle of West Virginia, it is about 150 miles wide. (See pl. 9.)

In the Appalachian region there are not many surface indications of oil and gas, although oil from a few springs, as along Oil Creek, in Venango County, Pa., and near Cuba, Allegany County, N. Y., was used by the Indians for medicinal purposes, and a number of seepages of natural gas, "burning springs," were known to the early settlers. During the first half of the last century oil was found in numerous brine wells, used in making salt, in western Pennsylvania, West Virginia, and southeastern Ohio. Some of these salt wells were

${ }^{23}$ Fettke, C. R., Oil resources in coals and carbonaceous shales of Pennsylvania: Pennsylvania Geol. Survey, 4 th ser., 1923. 
near Tarentum, in the New Kensington quadrangle. There was little use for the oil thus obtained, and the salt makers considered it a nuisance. Toward the middle of the century, however, when the whale-oil industry, which then furnished the main supply of illuminating oil, began to decline, it became necessary to find a substitute. A beginning in obtaining a new supply was made by distilling oil from coal and bituminous shale, but the new industry had not become established when it was abruptly terminated in 1859 by the discovery of oil in the Drake well.

The Drake well, in the valley of Oil Creek, Venango County, near Titusville, Pa., 60 miles north of the New Kensington quadrangle, was the first successful well drilled for oil. Down to 1865 production was practically confined to the valley of Oil Creek and adjacent areas, chiefly in Venango County, but in 1864 and 1865 oil was found near the southern boundary of the State in shallow sands in the valley of Dunkard Creek, Greene County. Although a number of years passed before the area between Oil Creek and Dunkard Creek was developed, fields were opened up in the decade beginning with 1865 in Clarion, Armstrong, and Butler Counties, and natural gas was discovered in the New Kensington quadrangle in 1874.

The Bradford field, in McKean County, Pa., and Cattaraugus County, N. Y., which has produced more oil than any other pool east of the Mississippi River, was discovered about 1871 and reached its peak in 1881. During these years excitement ran so high in the Bradford district that operations in other areas were almost suspended.

In 1882 discoveries in southern Butler County, at Baldridge and Thorn Creek, only a few miles north of the New Kensington quadrangle, marked the revival of the "lower country," and during the decade beginning with 1880 the Pittsburgh district was connected by pipe lines with several large natural-gas fields, including the Murrysville field, in Westmoreland County, the Hickory field, in Washington County, and the Tarentum field, in the New Kensington quadrangle. In 1886 several large wells in Washington County came in, and in 1889 the Brush Creek field, in Allegheny County, the Taylorstown field, in Washington County, and the Nineveh field, in Greene County, were opened up. The McDonald field, 10 miles southwest of the New Kensington quadrangle, which ranks as one of the great fields of the Appalachian region, was discovered early in 1891. The productive area of the State was in large part outlined before the end of the last century, and relatively few large fields, chiefly gas in the eastern part of the area, have since been discovered.

The peak of production of petroleum for the State of Pennsylvania was attained in 1891, when the annual output was over $31,000,000$ barrels, and from this high mark the production decreased rapidly. By 1912 the annual output of Pennsylvania had declined to less than 


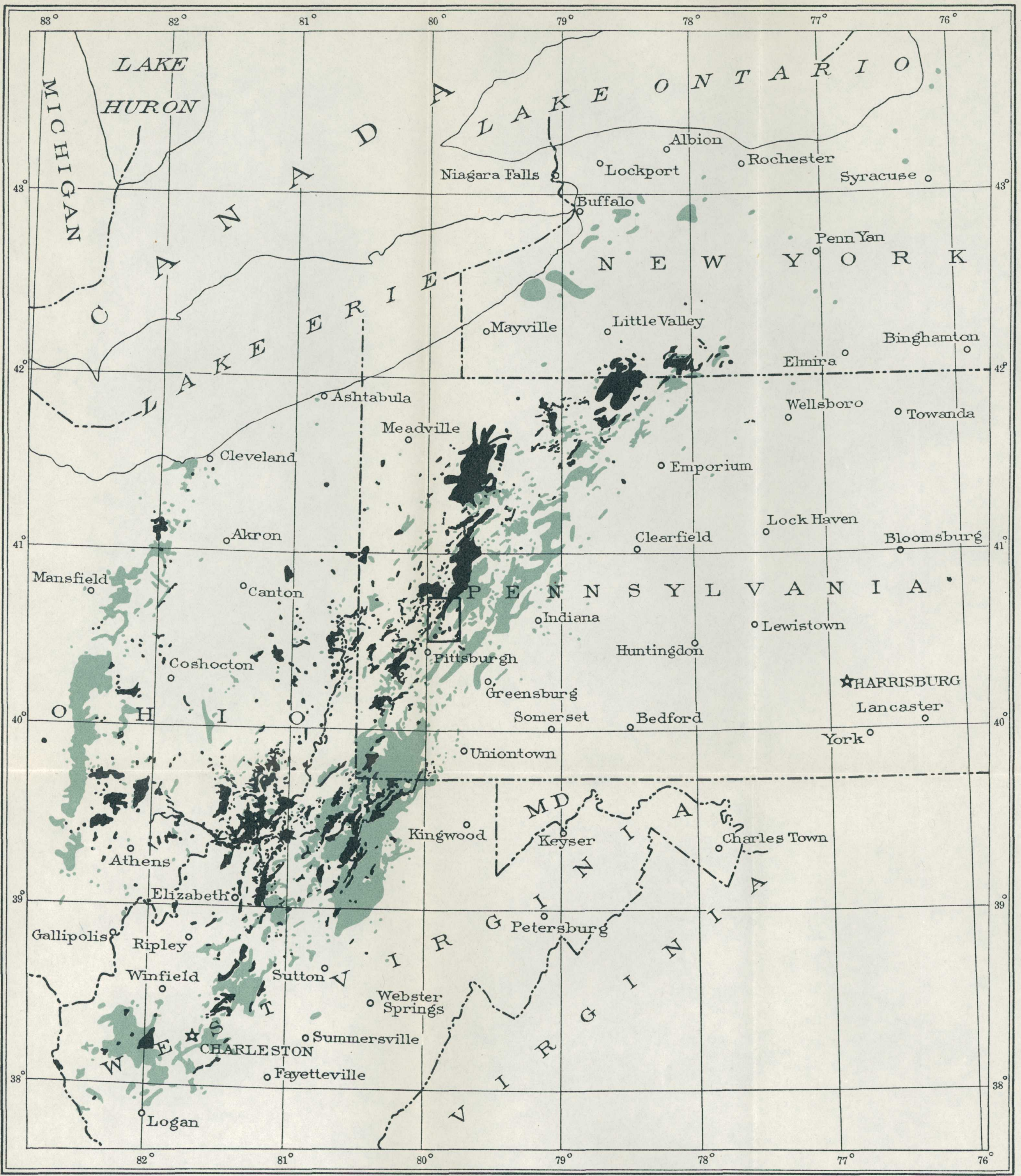

SKETCH MAP OF PART OF NORTHERN APPALACHIAN OIL AND GAS REGION

Compiled in cooperation with the State geological surveys

Black areas represent oil fields, shaded areas represent gas fields

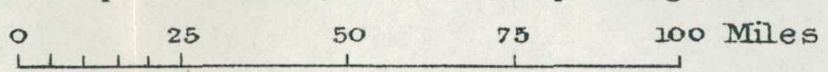


$8,000,000$ barrels, and during the following 12 years it was almost stationary. Since 1924, however, there has been an increasing output, due primarily to improved methods of recovery, chiefly flooding in the Bradford field. In 1927 the production of petroleum in Pennsylvania was more than $9,500,000$ barrels, or as much as it was 20 years previously. This output came from about 76,000 wells, and the average yield per well per day was only 0.3 barrel. These figures, in the absence of statistics for the New Kensington quadrangle, afford an indication of general conditions in this area.

The Appalachian field is underlain by beds of sandstone, shale, and limestone, ranging in age from Cambrian to Carboniferous, gently folded to form a synclinorium-the Pittsburgh-Huntington Basin. (See pl. 3 and fig. 3.) The productive strata are almost coextensive with the geologic column. (See table opposite p. 50.) From the Potsdam sandstone, of Upper Cambrian or Lower Ordovician age, small quantities of natural gas have been obtained in central New York. The Trenton limestone, of Middle Ordovician age, also has produced small quantities of gas in New York, and a limestone of Trenton or Black River age is the principal source of oil and gas in the Lima-Indiana field of northwestern Ohio and northeastern Indiana. The Albion sandstone, of Silurian age, is the source of much natural gas in western New York, and the so-called "Clinton" sand, at approximately the same horizon, has yielded large quantities of natural gas and oil in central Ohio. The eastward and southward continuation of this horizon has been the objective of deep drilling, but on account of the thickening of the section this horizon has not yet been reached by wells in southwestern Pennsylvania and northern West Virginia.

In Pennsylvania the lowest strata from which oil or gas in commercial quantities has yet been obtained, with the exception of small quantities of gas from a sand at or near the horizon of the Albion sandstone along the lake front in Erie County, were encountered in the deepest well near Ligonier, Westmoreland County. ,There, in Peoples Gas Co. well No. 1842, gas has been obtained from beds at two principal horizons-one, in what may prove to be the Cayuga group, at a depth of 7,440 feet, and the other, at a depth of 6,827 feet, in beds of doubtful age which may be in the Oriskany group or possibly in the Onondaga limestone. A limestone at or near the horizon of the Onondaga ("Corniferous") limestone, of Middle Devonian age, is the principal productive bed in Kentucky, and some gas has been obtained from a bed at this horizon in New York. Recently gas in wells of large initial capacity has been obtained in Tioga County, Pa., and in Schuyler County, N. Y., in the Oriskany sandstone.

The most productive oil and gas sands of Pennsylvania, West Virginia, and southeastern Ohio are of Upper Devonian and Mississippian 
age. Locally a small output is obtained from beds of Pennsylvanian age. Some of the oil sands, such as the Berea sandstone (Mississippian), are persistent over wide areas, but in general the beds are characteristically lenticular. The productive sands of Upper Devonian age, which are well developed in southwestern Pennsylvania and northern West Virginia, thin out and disappear to the west, and in northwestern Pennsylvania, southwestern West Virginia, and eastern Ohio their horizons are represented by shale.

The general stratigraphic position of the principal oil and gas sands in the northern Appalachian region is shown in the table opposite.

The Appalachian oil and gas fields are characteristically elongated and occur in alinement with the major structural trends. The productive sands commonly are lenticular beds, in which there are local streaks of coarser sand and gravel, that presumably were laid down parallel to the old shore lines of the sea in which the beds accumulated. Although a few of the oil and gas sands, in the Bradford field, for instance, maintain relative homogeneity over considerable areas, most of the sands are extremely variable and within short distances thicken or thin and merge with beds of different composition and texture. The sands show pronounced variations in porosity and permeability and differ in degree of cementation. Oil and gas occur in the more porous "open" parts of the beds, in places regardless of structure, and are absent from the less porous "tight" parts. Some of the most productive fields of the Appalachian region are located along the feather edge of lenticular beds.

Lithologic conditions play so important a part in the occurrence of petroleum in this area that there has been a tendency to underestimate the effect of structure, in spite of the fact that the anticlinal (structural) theory had its inception and first practical application in the Appalachian region. There is, however, in this as in other areas, a pronounced relation between the occurrence of oil and gas and the structure of the rocks. Gas tends to travel up the dip of the beds and is generally trapped in the tops of domes, the crests of anticlines, or the structurally high parts of lenticular sands. Water, on the other hand, tends to migrate down the dip into structurally lower parts of the beds. Oil, containing gas in solution, occupies an intermediate position between the gas and the water if all three are present. Where water is absent oil may be found on the lower flanks of folds and in synclines. Where water is present but gas does not occur in abundance oil may accumulate on the crests of anticlines. Where gas is plentiful it may occur not only along the crests of anticlines but on their flanks, and, in the absence of oil and water, even along the axes of synclines, especially in the upper parts of plunging synclines.

Although many questions concerning the origin of petroleum are still unanswered, there is general agreement among geologists that 
Principal oil and gas sands in the northern Appalachian region

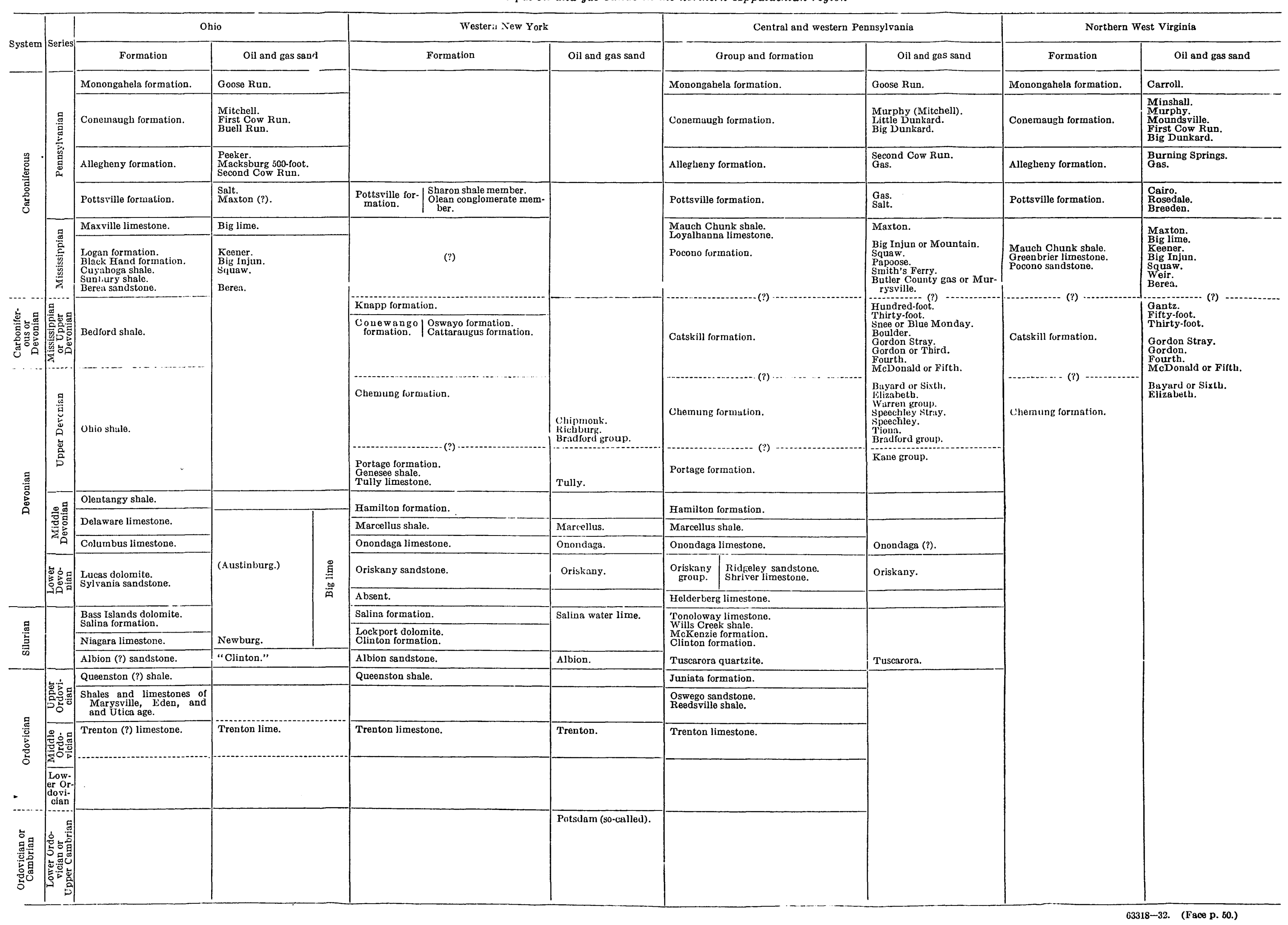


it is derived chiefly from certain aquatic plants and animals of low orders that accumulated in fine-grained clayey or calcareous sediments in the basins in which the oil sands were deposited. There are, however, differences of opinion regarding the mode of derivation of oil from the organic matter and the manner of accumulation in the reservoir rocks. Many incline to the belief that petroleum is generated by bacterial, chemical, and dynamic processes acting in the course of geologic time on the organic matter in the sediments. Oil may be driven from the source deposits and concentrated in the pore spaces of the reservoir rocks by the compaction of the source beds, capillarity, the expansive force of gas dissolved in the oil, diastrophism, the pressure of water, and gravitation. The occurrence of a relatively impervious cap or barrier, such as shale, compact limestone, or indurated sandstone, tends to prevent the escape of the hydrocarbons from the reservoir sands.

Little is known of the source beds from which the oil and gas of the Appalachian region were derived, but it is believed that they are chiefly the dark shales that are associated with the producing beds. Under favorable conditions locally abundant source material was laid down with the sediments that are interstratified with the reservoir rocks. In some fields there may have been comparatively little migration of the hydrocarbons. The varying productivity of certain areas seems to have been controlled by the porosity, size, and structure of the reservoir beds and by the varying content of organic material in adjacent source deposits.

\section{OIL AND GAS IN THE NEW KENSINGTON QUADRANGLE}

\section{GENERAL FEATURES}

The New Kensington quadrangle is situated in the east-central part of the northern Appalachian oil and gas region. (See pl. 9.) As early as 1845 small quantities of oil, associated with salt water in brine wells, were obtained in this quadrangle, but the oil had little value. The first successful well drilled in this area for oil and gas was sunk in 1874, 15 years after the completion of the Drake well. One of the first natural-gas pipe lines of any considerable length was laid in 1876 from a well at Lardintown, Clinton Township, Butler County, to a steel mill at Etna, a distance of about 17 miles. The quadrangle was rather generally drilled in the succeeding two decades, during which the main producing areas were discovered and the maximum output was obtained. Information concerning the production is meager. The wells in the Wildwood field (p. 62) possibly were as large as any others. One of these is reported to have begun at the rate of 1,300 barrels a day. For many years the yield of oil and gas from the New Kensington quadrangle has been very little, the average production of oil per well per day being only a fraction of a barrel. 
The economic-geology map (pl. 2) shows the location of the oil and gas wells which were found during the progress of the field work for the present report, but many wells in this area, probably several hundred, have been abandoned, and all trace of them has disappeared. Development here as in most other parts of the Appalachian region has progressed with little or no assistance from engineers and geologists. Except for skeleton well logs, reported by drillers, there are practically no subsurface data, and, notwithstanding the extensive operations that have been carried on, very little information is available concerning details of the occurrence of oil and gas. The available data are summarized in the following pages.

\section{OIL AND GAS SANDS}

Small quantities of oil were recovered from the Salt sand, in the Pottsville formation, in brine wells at Tarentum before the Drake well was drilled, but no oil has since been obtained in the New Kensington quadrangle from this source. Oil or gas in considerable quantities in this area have been found in sands ranging from the Butler County or Murrysville gas sand down to the Speechley. The top of the Murrysville sand lies abou't 1,200 feet below the Upper Freeport coal, and the interval in this area between the top of the Murrysville and the Speechley sand is 1,300 to 1,400 feet. The so-called Bradford sand, which lies about 600 feet below the Speechley, has been reached in only a few wells and no drill hole has yet been sunk to the Oriskany, "White Medina" (Tuscarora), or other very deep sands. Most of the oil and gas in this quadrangle has come from sands between the Murrysville and the Fifth, inclusive, which occupy a stratigraphic interval of 500 to 600 feet. In places production is obtained from the Speechley sand, but in the New Kensington quadrangle this sand has not yet been thoroughly tested. (See table of oil and gas sands, p. 50.)

The beds of sand that are encountered in drilling are illustrated in Plate 8, which consists of selected records of 34 wells representative of several hundred in different parts of the quadrangle. A number of other records, reported by townships, are given on pages $90-97$. In this report the well-known drillers' names for the oil and gas sands are used, with the understanding that they indicate only approximate stratigraphic position rather than identity with sands at the localities in which the names were first used.

Most of the records are in skeleton form and show only the depth to the beds of sand. The Hundred-foot sand is a fairly persistent marker, which is depended upon by the drillers, who generally determine the distance of the top of this sand below the surface by careful measurement; but on account of the lenticularity of the beds the "top of the Hundred-foot sand," as reported in the records, does not mark precisely the same horizon throughout the quadrangle. In the plotted sections of oil and gas sands, however, 
the "top of the Hundred-foot sand" is taken as the best available datum plane. The relation of the oil and gas sands to the surface rocks is indicated in some of the sections by the position of the Vanport limestone. (See pl. 8.)

As all the wells start in rocks that lie above the Pottsville formation and extend several hundred feet beneath it, they span the gap which marks the unconformity between rocks of Pennsylvanian and Mississippian age. Measurements of the distance between the horizon of the Upper Freeport coal and the top of the Hundred-foot sand show that in this area, notwithstanding the unconformity, the interval is rather constant. In most of the wells it ranges between 1,250 feet and 1,350 . feet and over considerable areas the variation is less than 50 feet.

Some of the records show an upper group of sands that occupy a stratigraphic interval of about 500 feet, which represent parts of the Pottsville and upper Pocono formations. These sands are called by the drillers the Seventy-foot or Salt, Sixty-foot, Forty-foot, Big Injun or Mountain, and Squaw sands. In the New Kensington quadrangle these upper sands have not produced oil and gas in commercial quantities although in parts of the Appalachian region the Big Injun is an important source of oil and gas and the Squaw sand also is locally productive. An unrecorded interval occupied chiefly by shale separates the Big Injun from the Murrysville sand, which is in the lower part of the Pocono formation.

The oil and gas sands from the Murrysville to the Fifth, inclusive, are members of a group of variable beds of sandstone and shale of which two-thirds or more is sandstone. The upper part of the group consists of two beds of sandstone known by the drillers as the Butler County gas or Murrysville and the Hundred-foot sands, each 100 feet more or less in thickness, which commonly are separated by 30 to 50 feet of shale. The lower part of the group consists typically of half a dozen thinner beds of sandstone and intervening shale. These sands are known as the Thirty-foot, Snee or Blue Monday, Boulder, Third, Fourth, and Fifth. The individual beds are variable and lenticular, and none of the sands maintain a uniform thickness over a large area. The beds thicken and thin and locally disappear by merging with shale. In some places several beds of sand combine to form a thick mass of sandstone, and in other places the sands are "broken" into alternating beds of sandstone and shale. In a given interval more beds of sand are present in one section than in another. Under these conditions it is practically impossible to identify the same beds over wide areas.

Below the Fifth sand, down to the Speechley sand, is an unproductive zone of 800 or 900 feet that consists chiefly of shale. Locally in the upper part of this zone there are lenses of sand, the Sixth and Elizabeth sands, and here and there in the central part of the zone 
are sands called by the drillers the Warren first and second sands, but correlation with the sands of Warren County has not been established.

Below this shaly zone are two sands, the Speechley Stray and the Speechley, both of which have yielded oil or gas and are sources of probable future production. These sands, each of which is 10 to 30 feet thick, lie between 1,200 and 1,300 feet below the top of the Hundred-foot sand and 2,500 to 2,600 feet below the Upper Freeport coal.

The lowest sand yet reached by drilling in the New Kensington quadrangle is the so-called Bradford sand, which lies about 600 feet below the Speechley. This sand has not been thoroughly tested, and its equivalence with the Bradford sand of McKean County has not been established.

The sandstones comprising the group of oil and gas sands from the Murrysville to the Fifth, inclusive, range in texture from fine to coarse grained, and not uncommonly they are conglomeratic. Considerable variation in shape and size of grains is shown within short distances, and there is little or no regularity in the distribution of grains of similar size other than a more common sorting along the strike of the rocks, presumably caused by currents that flowed parallel to old shore lines. The grains of some of the fine-textured sandstones are as small as 0.15 millimeter, and some of the pebbles of the coarser beds are more than 1 centimeter in diameter.

In composition the sands are chiefly quartzose, but besides grains of quartz they contain decomposed feldspars, kaolinite, flakes of muscovite, and a few bits of ferromagnesian minerals, cemented chiefly by silica and subordinate calcite. The sandstones vary in degree of cementation; in general they are thoroughly indurated, but locally they are somewhat soft. The pay streaks, the pore spaces of which are occupied by oil and gas, are comparatively uncemented and, as reported by the drillers, are soft and "open," in contrast to the barren parts of the sand, which are hard and "tight."

The porosity of a number of pieces of sandstone that were shot from oil wells in the New Kensington quadrangle has been determined by A. F. Melcher, ${ }^{24}$ as shown in the following table.

Porosity of sands from wells in New Kensington quadrangle

\begin{tabular}{|c|c|c|}
\hline Well & Sand & $\begin{array}{l}\text { Pore space (per- } \\
\text { centage by } \\
\text { volume) }\end{array}$ \\
\hline 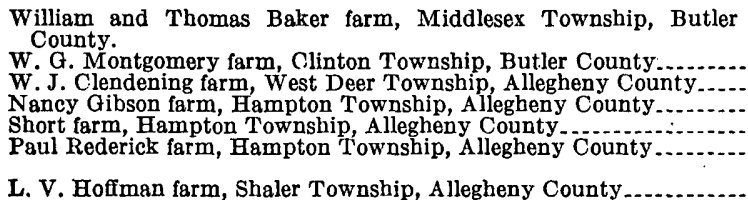 & 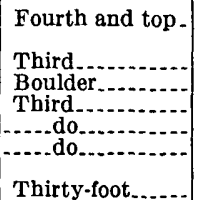 & $\begin{array}{r}15.9,11.5,10.0 \\
10.4,12.0,10.6 \\
12.6,8.3,6.2 \\
4.8,8.1,4.6,7.5 \\
5.0,6.0 \\
8.2,6.1,6.6 \\
9.1,7.6 \\
9.5,9.3,9.0,9.8\end{array}$ \\
\hline
\end{tabular}

24 Melcher, A. F., Texture of oil sands with relation to the production of oil: Am. Assoc. Petroleum Geologists Bull., vol. 8, pp. 738-741, 1924. 
The chunks of rock were reported, when collected at the wells, to be samples of the pay sand, but the low porosity of some of the samples suggests that they do not represent the pay streaks, which on account of their softness are more difficult to obtain in shooting the well than the relatively harder parts of the rock. The samples showing very low porosity probably represent "tight" parts of the sand, or possibly the cap rock. For comparison it may be noted that the porosity of the Bradford sand in McKean County, Pa., averages about 15 per cent.

No core samples of the oil sands in the New Kensington quadrangle have yet been taken. Core drillings, however, will be one of the future developments, for it is only by the study of actual specimens of the rocks, such as are furnished by cores, that the composition, texture, porosity, and permeability of the oil sands can be determined. Such studies are necessary prerequisites to the most successful practice of improved methods of oil recovery.

\section{OIL FROM BRINE WELLS AT TARENTUM}

Oil developments in the vicinity of Tarentum preceded by more than 10 years Colonel Drake's successful drilling for oil at Titusville. In 1845 oil that came up with salt water from a brine well at Tarentum was combined with sperm oil and used for lubrication in the Hope cotton factory at Pittsburgh, ${ }^{25}$ and it is reported that this use of oil was continued for several years. It is also reported that refined oil from the salt wells at Tarentum, known as carbon oil, was used as as an illuminant in Pittsburgh between 1850 and 1855. About 1849 S. M. Kier opened an establishment at Pittsburgh, where oil from the salt wells at Tarentum was put up in half pint bottles and sold at 50 cents a bottle, labeled as follows:

Kier's petroleum or rock oil. Celebrated for its wonderful curative powers. A natural remedy. Procured from a well in Allegheny [County], Pa. Four hundred feet below the earth's surface.

Salt wells were drilled on both sides of the Allegheny River at Tarentum. The largest oil well was the property of Irwin \& Peterson, which is reported to have produced at irregular intervals from 2 to 10 barrels of petroleum a day. Adjoining this property were the salt wells of Samuel and James Kier, which yielded about 2 barrels of oil a day. South of the Kier works was the salt well of Lewis Peterson and Doctor Dale, of Pittsburgh, which likewise yielded a small quantity of petroleum. ${ }^{26}$

A. C. Ferris, who was attracted to petroleum in 1857 by seeing oil from Tarentum burning in a whale-oil lamp, purchased the property on which the wells were located. $\mathrm{He}$ conceived the idea of

25 The Derrick's Handbook of petroleum, p. 11, Oil City, Pa., 1898.

20 Idem, p. 13. 
sinking a shaft in order to increase the supply of petroleum, and it is reported that a shaft 12 feet square was sunk about 200 feet. Afterwards a well was started from the bottom of the shaft, with a view to drilling down to the rock from which the crude oil was obtained, but the undertaking was abandoned on account of the large quantity of water encountered. These events were contemporaneous with Bissell's and Eveleth's investigations in the valley of Oil Creek, which led to the drilling of the Drake well. In 1858 the total production of petroleum is reported to have amounted to 1,183 barrels, of which 1,008 barrels came from the two wells at Tarentum and the remainder from Enniskillen, Canada. The price of petroleum then was $\$ 1$ a gallon. ${ }^{27}$

The salt wells at Tarentum were started at or near the horizon of the Upper Freeport coal, and as the oil and salt water came from a depth of about 400 feet, the productive bed was a sandstone in the Pottsville formation.

\section{EARLY OIL AND GAS WELLS}

The success of the Drake well and the developments along Oil Creek and in the upper Allegheny River Valley diverted attention from the Tarentum district, and it was not until 15 years after the completion of the Drake well that the first commercially successful well was drilled for oil or gas in the New Kensington quadrangle.

In the fall of 1874 a strong flow of gas was struck at a depth of approximately 1,200 feet in a well on the William Harvey farm, near Lardins Mill, now called Lardintown, Clinton Township, Butler County. Measurements of pressure and capacity were not made, but in 1885 the Harvey well was reported to have been "the most powerful gas well in the section." 28 In 1875 the well was purchased by the Natural Gas Co. (Ltd.)--one of the earliest naturalgas companies-and after blowing wild for about a year the gas was piped about 17 miles through a 6 -inch pipe to the iron mill of Spang, Chalfonte \& Co., at Etna, in Shaler Township, Allegheny County. The gas was turned into the pipe in October, 1875, and traveled the 17 miles in 20 minutes. This is said to be the first instance of natural gas being piped any considerable distance for industrial use, although in 1871 gas was used in iron making at Leechburg, $\mathrm{Pa}$., from a near-by well, and in 1872 gas was piped 51/2 miles to Titusville. After these demonstrations of the possibilities of natural gas its use increased tremendously, and between 1883 and 1885 several natural-gas pipe lines were laid to Pittsburgh.

In 1878 another gas-producing area was opened up in the quadrangle, near Tarentum, and in the next eight years many gas wells

27 The Derrick's Handbook of petroleum, p. 17, Oil City, Pa., 1898.

29 Weeks, J. D., Natural gas in 1885: U. S. Geol. Survey Mineral Resources, 1885, p. 172, 1886. 
of large capacity were drilled in what came to be known as the Bull Creek field. An early well in this field, put down by Guffey \& Galey, is described as "one of the largest ever found," ${ }^{29}$ but no records of measurements are available. The well was sold to the Philadelphia Co., and the gas was piped to Pittsburgh.

Development of the petroleum resources of the New Kensington quadrangle, after the early exploitation of the oil obtained from the salt wells at Tarentum, was not continued until about 1887, when wildcatting, proceeding southward from the Thorn Creek field, Butler County, a few miles north of the quadrangle, opened up the district west of Saxonburg, in Jefferson Township, Butler County. After this activity development extended rapidly, and by 1898 most of the oil-producing areas of the quadrangle had been discovered. Drilling during the succeeding 30 years has only slightly extended these areas.

\section{P.RINCIP.AL PRODUCING AREAS}

Saxonburg-Lardintown.-The Saxonburg-Lardintown area, in Jefferson, Winfield, Clinton, and Buffalo Townships, Butler County, is the southwestern continuation of the large gas-producing area .situated along the Kellersburg anticline, in the Butler and Kittanning quadrangles. Gas was found in 1874 in a well on the Harvey farm, near Lardintown. This well produced large but unmeasured quantities of gas for a period of about 10 years, when it was drowned .out. By 1885, 12 additional wells had been drilled in the vicinity of Lardintown, and the gas was piped to Etna, in the southwestern part of the quadrangle. Since then there has been intermittent drilling throughout this area. (See pl. 2.)

Structurally this field is situated along the axis and upper flanks of the southwestward-plunging Kellersburg anticline. This anticline is the most strongly developed fold in the quadrangle, and the occurrence of gas along its axis and upper flanks is in accord with the anticlinal or structural theory, by which natural gas, which is of relatively low specific gravity, is assumed to accumulate in structurally high parts of strata.

Gas was obtained at a depth of about 1,200 feet from the Butler County gas sand (Murrysville) in the wells at Lardintown, which :started at or near the Upper Freeport coal. Later, when this sand gave evidence of depletion, wells were sunk to lower sands, as deep as the Speechley. Gas has been found in one place or another in this field in the Murrysville, Hundred-foot, Thirty-foot, Fourth, Fifth, and Speechley sands, but not in all these sands in any one well, and the productivity of even adjacent wells is characteristically different. Variable conditions in the sand apparently are the cause

20 Weeks, J. D., Natural gas in 1883-84: U. S. Geol. Survey Mineral Resources, 1883-84, p. 240, 1885. $63318-32-5$ 
of the varying yield of different wells. The pay streaks in the productive sands are reported by the drillers as soft and "open," and the nonproductive sands are said to be hard and "close." The fact that recent wells of good capacity are brought in adjacent to exhausted wells that formerly produced from the same sand proves the absence of free communication.

Water is reported in this field in the Hundred-foot sand and in those above it. The sands below the Hundred-foot are said not to contain water. Some of the wells in this field are reported to cause trouble by "salting up"; that is, becoming clogged by common salt deposited by evaporation of the water, in which the salt was dissolved.

A typical log of a well in this field is given below:

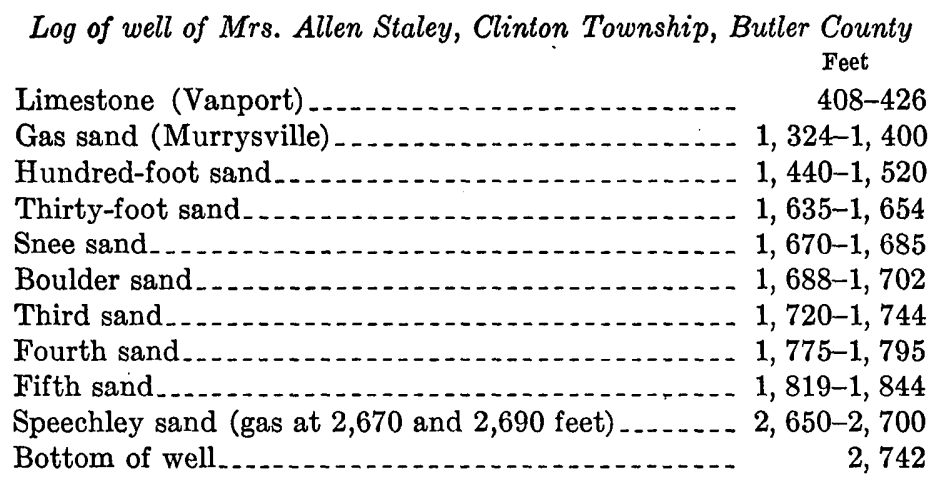

The Speechley sands have not been thoroughly tested on the Kellersburg anticline and presumably they will be found to be productive at a number of places in this field. Like the other sands they are of varying porosity. In one place a sand may be close textured and of low porosity, and not far away it may be a loose-textured open reservoir. The so-called Bradford sand has been but little tested in this area.

Bull Creek-Tarentum.-In 1878, four years after the discovery of gas near Lardintown, natural gas was found in a well in the vicinity of Tarentum, which was the forerunner of the development of the Bull Creek field. In 1883, after three or four unsuccessful wells had been sunk, a large gas well was brought in about a mile above the mouth of Bull Creek. Carll ${ }^{30}$ reports that this well started a development that resulted in defining one of the most productive gas fields of the country. By 1885 more than 20 wells had been drilled, and the supply of gas was ample for the town of Tarentum, the large plate-glass works at Creighton, and the Pennsylvania Salt Manufacturing Co. at Natrona, a few miles east of Tarentum. The Philadelphia-Westinghouse Co. piped gas from this field to Pitts-

\footnotetext{
so Carll, J. F., Preliminary report on oil and gas: Pennsylvania Geol. Survey Ann. Rept. for 1885, p. 37,
} 1886. 
burgh, a distance of about 22 miles. In his report for 1886 Carll stated that this gas field had passed its prime, owing to excessive drilling and flooding by salt water.

In the early wells the gas was obtained from the Murrysville sand at a depth of about 1,200 feet below the Upper Freeport coal, which crops out in the valley of Bull Creek. (See pl. 2.) Later wells were drilled to deeper sands, and gas has been found in the Hundred-foot, Boulder, Third, Fourth, and Fifth sands. Next to the Murrysville; the Fourth sand has yielded the most gas.

The Murrysville sand is about 100 feet thick, but detailed descriptions of it are not available. The Fourth sand ranges from 20 to 30 feet in thickness, and the pay streak is reported to be conglomeratic. Throughout the field all the sands vary in porosity, and where the sands are hard and compact they are nonproductive. In some wells, as in one on the D. K. Keowen farm, East Deer Township, all the sands from the Hundred-foot to the Fourth, inclusive, are said to be hard and "close." In this well gas is obtained in the top of the Fifth sand. No water below the Murrysville is found in this well.

In general water is reported absent in the sands below the Hundredfoot, and although water is commonly present in the Murrysville sand it is reported to be absent from that sand on the highest part of the Amity anticline, in the southern part of Fawn Township, but down the flanks of the anticline the Murrysville sand is water-bearing. Some of the wells in the Bull Creek pool have caused trouble by "salting up."

Structurally the Bull Creek gas pool is situated along the axis of the Amity anticline; the best wells were located on a knob or "high" on the axis of the fold about 2 miles north of Tarentum. So far as the writer is aware, the deeper sands have not been tested in this pool, and when such tests are made this structural "high" doubtless. will be explored.

Milltown-Natural gas was found in the valley of Plum Creek near Milltown in the Fifth sand in 1891, and during the succeedingtwo years a number of gas wells were obtained in that sand in Plume and Penn Townships, Allegheny County. The wells were situated along the axis and flanks of the Amity anticline. In 1894, after the gas supply had considerably diminished, oil was obtained from the Hundred-foot sand, about 400 feet nearer the surface. This sand had been ignored in the earlier drilling. Since 1894 there have been several periods of revived interest, each following the completion of an unusually good well, and these townships have been rather thoroughly drilled down to the Speechley sand, in which some gas has been obtained.

The occurrence of both oil and gas in Penn and Plum Townships is characteristically "spotted." In the midst of an area of dry holes 
good wells have been brought in, and the many wells that have been sunk have resulted in the discovery of numerous small disconnected productive areas. Varying conditions in the sand seem to be the cause of the "spotted" production. Oil pay streaks in the Hundredfoot sand are described as "nice pebbly sand," and unproductive sands are reported to be "hard and tight." The Hundred-foot sand commonly has two pay streaks, the upper one occurring 40 to 60 feet below the top of the sand. In the Hoffey well No. 6, for instance, the Hundred-foot sand occurs from 1,840 to 1,932 feet below the surface, the first oil pay from 1,880 to 1,890 feet, and the second from 1,915 to 1,925 feet.

The following well record shows the general depth, thickness, and succession of sands in Plum Township. Wells have been sunk deeper in that township than in any other part of the quadrangle, the so-called Bradford sand having been reached at a depth between $.3,600$ and 3,700 feet.

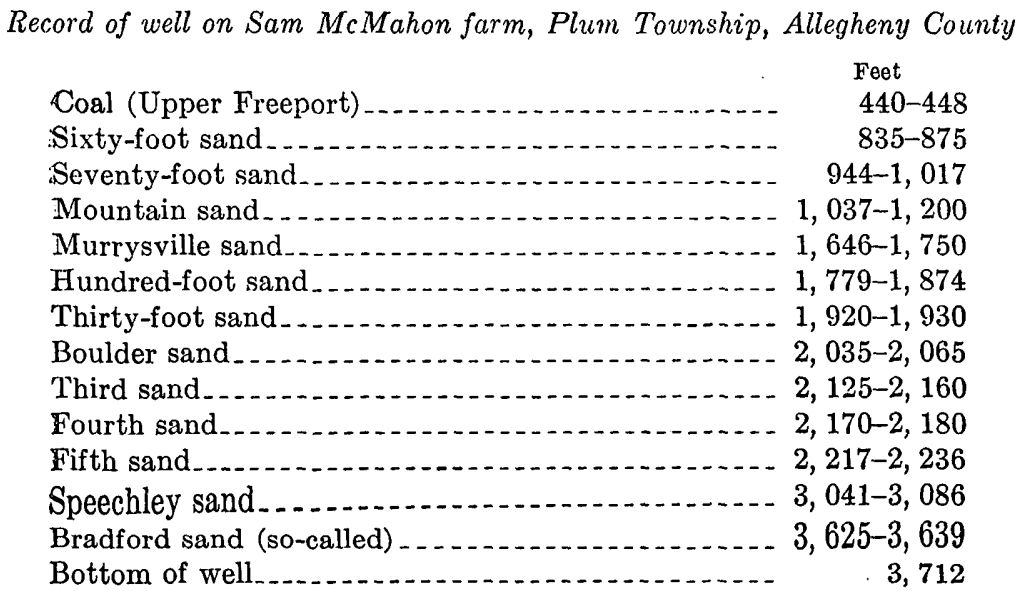

Water is reported in all of the sands down to and including the Hundred-foot, but the sands below the Hundred-foot are reported to yield no water. Oil and water are obtained together from the Hundred-foot sand.

Bakerstown.-The largest oil-producing area in the New Kensington quadrangle is situated northeast and east of Bakerstown. This area extends from the vicinity of Clinton Church, in Clinton Township, southwestward to the vicinity of Sandy Hill School, in Middlesex Township, Butler County, and thence southeastward, east of Deer Creek Church, in West Deer Township, Allegheny County.

In 1888 oil was discovered on the Gold farm, a mile northeast of Sandy Hill School, and on the Montgomery farm, between Deer Creek Church and Culmerville. Several large wells were obtained, and the area was rapidly drilled. After a decade, during which production had considerably declined, renewed activity followed the 
bringing in of unusually good wells in an area surrounded by old onesThere have been several later periods of renewed activity in this area, each following the bringing in of an extraordinary well in one place or another.

Although but little detailed information concerning the mode of occurrence and the production of oil in the Bakerstown area is available, the following statements afford some indication of conditions. The principal oil-producing bed is a sand which in some records is called the Third and in others the Fourth. Locally these two sands seem to coalesce by the disappearance of the intervening shale. The pay streak is unusually thick, being reported between 15 and 20 feet in several wells. Gas has been found locally in the Hundred-foot, Thirty-foot, and Boulder sands and also in the Speechley sand, in a few wells that have been sunk to that horizon.

The following log of a well put down in 1912 by the T. W. Phillips Gas \& Oil Co. indicates the general sequence of the rocks. This log is an unusually complete one for this quadrangle.

Log of well No. 4, Thomas Marshall farm, West Deer Township, Allegheny County

\begin{tabular}{|c|c|}
\hline Clay, & $\begin{array}{l}\text { Feet } \\
0-14\end{array}$ \\
\hline 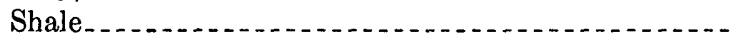 & $14-65$ \\
\hline Sand (water) & \\
\hline Shale, dark & $70-17$ \\
\hline Coal & \\
\hline hale, light. & \\
\hline oal & \\
\hline , dark & $354-47$ \\
\hline one, Vanport & $475-48$ \\
\hline 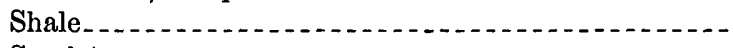 & $485-50$ \\
\hline${ }^{\prime}$ & $505-$ \\
\hline$k+k^{\prime}$ & $535-64$ \\
\hline & $645-96$ \\
\hline Sh & 960-99 \\
\hline${ }^{\prime}$ & $990-1,04$ \\
\hline 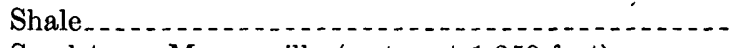 & $-1,31$ \\
\hline , Murrysville (water at 1,350 feet) & $-1,4$ \\
\hline 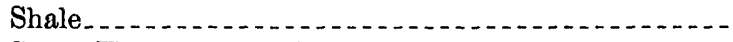 & $-1,4$ \\
\hline Hundred-foot (very hard) & $-1,5$ \\
\hline 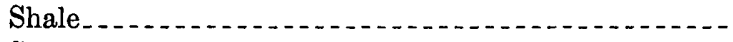 & $1,580-1,61$ \\
\hline Sandstone, Thirty-foot (hard and close) & $12-1,6$ \\
\hline (n-1-1 & $345-1,6$ \\
\hline Sandstone, Blue Monday (broken) & $1,670-1,6$ \\
\hline 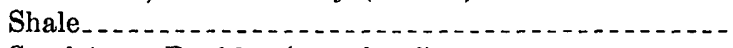 & $1,678-1,6$ \\
\hline one, Boulder (very hard) & $1,682-1,7$ \\
\hline (2) & $-1,7$ \\
\hline il pay at $1,802-1,809$ & \\
\hline
\end{tabular}

It will be observed that the sands above the Fourth, which are productive of oil and gas in other parts of the New Kensington quadrangle, are reported to be either "hard" or "broken." 
Varying porosity of the Third and Fourth sands, sufficient to cause lack of communication for oil and gas, is indicated by the bringing in of good new wells, under considerable pressure, in close proximity to old wells of small yield under low pressure. An illustration of the varying porosity of these sands is afforded by the results of drilling on the Sterling and Rittman farms, west of Culmerville. Near the boundary line between these farms a narrow streak of soft "open" sand, highly productive of oil, is reported in the midst of hard, "tight" sand in which dry holes were sunk.

Water in considerable quantity is reported in the Hundred-foot and overlying sands. The sands below the Hundred-foot are said to have been dry when the area was first drilled, but the later wells in the Third and Fourth sands have encountered more or less water, which is believed to have come down from the upper sands through faulty plugging of old wells.

Structurally the Bakerstown field is situated low down on the flanks of the southwestward-plunging Kellersburg anticline, adjacent to the axis of the Bradys Bend syncline and to the cross trough that interrupts the continuity of the axis of the Kellersburg anticline.

Production from the Bakerstown field has been "spotted." This is illustrated by the fact that 20 years after the pool was opened, a well in the midst of old producing territory, in which the average yield per well per day was less than a barrel, was brought in with an initial production of 1,000 barrels a day. This well was the David Scott No. 5, drilled in 1910. The Thomas Marshall well No. 1, drilled in 1909, is credited with a production of 3,000 barrels during its first month of operation. This well was abandoned in 1916. Other wells on the Thomas Marshall farm had an initial production varying between 5 and 75 barrels a day. Well No. 1 on the Charles Porter farm, drilled in 1900, had an initial production of 125 barrels a day; in 1921 its output was half a barrel a day. Well No. 1 on the W. A. Allison farm, drilled in 1908, yielded gas in the Hundred-foot sand at a depth of 1,705 feet and gas in the Speechley sand at a depth of 2,700 feet.

Wildwood.-The Wildwood field in Hampton and McCandless Townships, Allegheny County, is another Third sand area which formerly produced large quantities of oil. Now, however, by present methods of extraction, the field is practically exhausted, and only a few wells remain to mark the site of this once highly productive area. It extended from the vicinity of Wildwood southwestward a distance of about 3 miles, half of it being beyond the limits of the New Kensington quadrangle. The field was discovered about 1889 and was rapidly developed. Early in 1890 several gushers were reported to flow at rates between 70 and 150 barrels an hour. The highest daily average production for the field, estimated by the Oil City Derrick 
at 18,500 barrels, was attained in January, 1891, and by December of that year the daily output had decreased to 2,500 barrels.

Few details concerning the occurrence of the oil in this field are available. Only the Third sand is said to have been productive. This sand ranges from less than 20 feet to about 40 feet in thickness and the pay, occurring in the lower part of the bed, ranges from 2 to 15 feet. The pay streak is reported as "loose," and the upper part of the Third sand as "tight." Water is reported to be absent from the Third sand in this area.

At its northeast end the Wildwood field lies along the western flank of the Kellersburg anticline, and southwestward the field seems to lie in a synclinal wrinkle between the Kellersburg anticline and the Wildwood anticline of the Sewickley quadrangle. The detailed structure of the surface rocks in this area is obscure, and not enough well records are available to show the lay of the oil sand.

Evergreen.-The Evergreen field, situated in the valley of Girty Run, a mile north of the town of Evergreen, in Ross Township, Allegheny County, is less than a mile long and only a quarter of a mile wide. It was discovered about 1899 and in its prime is reported to have had only 8 pumping wells. In July, 1917, when the field was visited, but 1 well was in operation, Warner No. 4, which was sunk in 1908 and had an initial production of 6 barrels.

This field is adjacent to the axis of the plunging Kellersburg anticline, $2 \frac{1}{2}$ miles down the slope from the knob along the axis in Hampton Township. The oil occurs in a pocket of soft porous sand that is surrounded by sand which according to the driller's report is "hard, glassy, and tight." The productive bed is the Third sand, which is reported to have been originally dry of water, although now some water enters the wells from the Hundred-foot sand. The top of the pay streak is about 20 feet below the top of the Third sand and is 5 to 10 feet thick. The rest of the sand is hard and dry.

Record of Warner well No. 7, Evergreen field

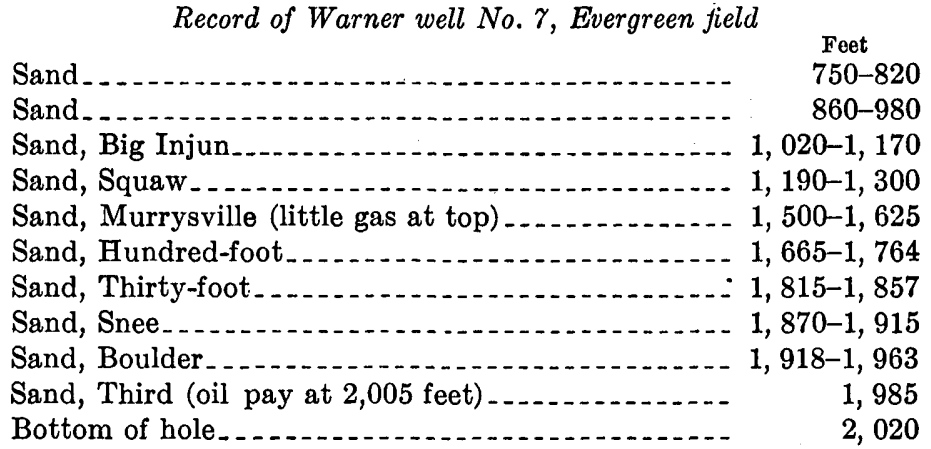

Dorseyville.-The Dorseyville Thirty-foot sand field, southeast of Dorseyville, in Indiana Township, Allegheny County, was discovered in 1913 and was rapidly developed during the succeeding few years. 
A small quantity of oil was found in the Hundred-foot sand, but the main pay is the underlying Thirty-foot sand. This field occupies a few acres which escaped discovery during the early drilling, notwithstanding the numerous wells that were put down in the vicinity.

Such a discovery is typical of the occasional finds in the Appalachian region, which furnish incentives to maintain the drilling that goes on year after year in these old fields. The Evans City oil field, in Butler County, and the McKeesport gas field, in Allegheny County, are other comparatively recent discoveries of small but highly productive areas situated in the midst of old producing territory.

When first developed the oil in the Dorseyville field was under considerable gas pressure, and a number of the wells were gushers. The Haas well No. 2 is reported to have had an initial production of 1,140 barrels in 24 hours, and the initial output of the Robinson well No. 4 was 557 barrels. However, because of the small area, the rapid development, and the thinness and variability of the pay streaks the production soon declined, and in 1920 the average production per well per day in this field was less than 1 barrel. Structurally the Dorseyville field is situated on the southeastern flank of the Kellersburg anticline.

Several records of wells in the Dorseyville field, showing details of the Thirty-foot sand, were furnished by the National Oil \& Gas Co., of which the following is typical:

\begin{tabular}{|c|c|}
\hline \multicolumn{2}{|l|}{ Record of Hoeveler well No. 1, Dorseyville field } \\
\hline Coal, Upper Freeport.- & $467-473$ \\
\hline Coal-12 & $621-627$ \\
\hline Coal & $761-766$ \\
\hline Sand & $858-1,043$ \\
\hline Sand, Big Injun. : & $1,113-1,267$ \\
\hline Sand, Squaw . . . . & $1,318-1,456$ \\
\hline Sand, Murrysville $\ldots \ldots \ldots$ & $1,653-1,753$ \\
\hline Hundred-foot sand: & \\
\hline Sand, top of Hundred-foot & 1,789 \\
\hline Sand, oil & $1,816-1,825$ \\
\hline Sand, hard, white & $1,825-1,835$ \\
\hline Shale & $1,835-1,880$ \\
\hline Shale, red & $1,880-1,885$ \\
\hline Shale & $1,885-1,890$ \\
\hline Sand, base of Hundred-foot & $1,890-1,896$ \\
\hline Shale & $1,896-1,920$ \\
\hline Thirty-foot sand: & \\
\hline Sand, top of Thirty-foot.... & 1,920 \\
\hline Shale.......... & $1,932-1,934$ \\
\hline Sand, hard, white & $1,934-1,940$ \\
\hline Sand, oil pay & $1,940-1,949$ \\
\hline Sand, hard, white & $1,949-1,954$ \\
\hline Sand, oil pay & $1,954-1,959$ \\
\hline Bottom of hole & 1,959 \\
\hline
\end{tabular}


This well began producing oil June 11, 1913, yielding 12 barrels a day. When the first pay sand was reached, at a depth of 1,940 feet, the oil rose in the well 1,000 feet, and when the second pay was reached, at a depth of 1,954 feet, the oil rose within 4 feet of the surface.

In the Dorseyville field the Thirty-foot sand ranges in thickness from 15 to 70 feet. There are usually two and locally three pay streaks, which are reported as "good, soft sand," ranging in texture from fine-grained to pebbly. Those parts of the Thirty-foot sand that do not contain oil are reported as "hard and tight." The pay streaks are not persistent but occur irregularly. In a few wells the first pay occurs at the top of the sand, but usually the upper part is barren. The pay streaks range in thickness from 1 to 16 feet and average between 3 and 5 feet. Very little or no water is reported as originally occurring in the Thirty-foot sand.

The measurements of the Hundred-foot and Thirty-foot sands in the Dorseyville field given on pages 86-89 show their composition and variation. The sections not only show local conditions in these sands but are believed to be typical of lithologic conditions in many other Appalachian fields. Similar detailed sections are not available for any other field in the New Kensington quadrangle.

Glenshaw.-The Glenshaw field, a few miles southwest of the Dorseyville field, is similarly situated along the southeastern flank of the Kellersburg anticline. It is in Shaler, O'Hara, and Indiana Townships, Allegheny County, and extends for a distance of about $2 \frac{1}{2}$ miles northeast of Glenshaw. As in the Dorseyville field, the production is from the Thirty-foot sand. The Glenshaw field was discovered in the nineties, when several good wells were obtained, but the field proved to be "spotted," and development has proceeded by a series of spurts following the bringing in of good wells.

A well on the S. N. Murphy farm, completed in 1899, is reported to have had an initial daily production of 800 barrels, and in 1917 this well produced 18 barrels a month. Very little or no water is said to have been produced with the oil. In this well the top of the Thirtyfoot sand was found at a depth of 1,927 feet, and the pay streak at 1,957 to 1,980 feet. The pay sand, as in most good wells in this quadrangle, is reported by the driller to be coarse and "open," whereas barren parts of the sand are compact and "tight." An illustration of varying conditions in the sand is afforded by the fact that in a dry hole sunk 280 feet southeast of the Murphy well no "open" sand was found and there were no indications of gas or oil in the well. In the Glenshaw field the pay sand is commonly pebbly.

Millerstown-A group of oil wells northwest of Millerstown, Fawn Township, Allegheny County, typifies the effect of favorable lithology in the occurrence of oil. In this area the productive bed is the Fifth 
sand. All the other sands down to and including the Speechley, which, however, is said to have been tested in only one hole, are barren and are reported to be "hard and close." In a well on the George Thompson farm the top of the Fifth sand is 1,968 feet below the surface. The first pay is pebbly sand from 1,978 to 1,980 feet, and the second pay consists of 1 foot of pebbles from 1,985 to 1,986 feet. The rest of the sand is reported hard and fine. The Fifth sand here is said to carry some water locally, but whether it occurred originally in the sand or came down from above is not known. This field is situated along the lower southeastern flank of the Kellersburg anticline.

Glade Run.-In the valley of Glade Run in the northwest corner of the quadrangle there are a number of wells which produce small quantities of oil from the Hundred-foot sand and which are typical of numerous wells in the Hundred-foot sand farther west and northwest, beyond the limits of the quadrangle. In this region the Hundred-foot sand, unlike the lower oil and gas sands, contains water in abundance, and where oil is present in this sand usually oil and water are produced together, commonly several times as much water as oil.

A few wells that were put down as long ago as 1890 and came in with an initial production between 50 and 100 barrels a day were still in operation in 1917, though producing only a fraction of a barrel a day. Other wells, however, were not so good; for instance, No. 1 on the Dorsey farm, put down in 1901, had an initial production of 10 barrels of oil and in 1917 produced less than 1 barrel of oil and 6 or 7 barrels of water a day.

The Hundred-foot sand in this area commonly has a parting or "break" of shale near the middle of the bed which separates the upper and lower pay streaks. The following record of a well in Adams Township is typical:

\section{Record of well on Nicholas farm}

Hundred-foot sand:

Feet

Top of sand

1,431

First oil pay................... 1, 453-1, 463

Shale break . . . . . . . . . . .

Second oil pay ................... 1, 478-1, 485

Bottom of well

The initial production was 48 barrels of oil a day, and enough gas was obtained with the oil for operation.

A few wells sunk below the Hundred-foot sand in this area obtained oil from the Fourth sand. Thus in well No. 1 on the M. J. Crooks farm the top of the Fourth sand was reached at 1,759 feet, the bottom at 1,800 feet, and the pay streak, 11 feet thick, between 1,772 and 1,783 feet. This well had an initial production of 50 barrels a day, and in 1921 it produced about half a barrel a day. 
Structurally these wells are situated on and near the crest of a broad arch that forms part of a southwestward-plunging anticline that extends across the Butler quadrangle, to the north.

\section{COMPOSITION OF THE NATURAL GAS}

Ten samples of natural gas from the Murrysville, Hundred-foot, Thirty-foot, Third, Fourth, and Fifth sands were collected by the writer during the summer of 1917 from wells in different parts of the quadrangle and analyzed at the laboratory of the Bureau of Mines at Pittsburgh, A. C. Fieldner, chief chemist. The gas analyzed contained methane $\left(\mathrm{CH}_{4}\right)$ and ethane $\left(\mathrm{C}_{2} \mathrm{H}_{6}\right)$ in varying proportions, with small amounts of nitrogen and carbon dioxide. The gas from wells yielding gas only and no oil is rich in methane, the percentage of which in the samples tested ranged from 26.3 to 96.7, whereas the gas from wells yielding both oil and gas contains a smaller amount of methane and correspondingly more ethane. The percentage of ethane shown by the analyses ranges from 1.8 to 73.6. Propane $\left(\mathrm{C}_{3} \mathrm{H}_{8}\right)$ and higher paraffins were not reported in any of the samples. analyzed.

Analyses of two samples of gas (B and L) from quadrangles adjacent to the New Kensington are given in the table. Sample $B$ represents mixed gas from the Fifth and Speechley sands from a well near Cabot, in the Butler quadrangle, about 2 miles north of the New Kensington quadrangle. Sample L represents gas from a sand in the Oriskany group in well No. 1588 of the Peoples Natural Gas Co., on the Booth \& Flinn tract, near Ligonier. The gas came from a depth of 6,822 feet, and at the time the well was completed in 1920, it was the deepest producing well in the world.

Analyses of natural gas from New Kensington quadrangle

\begin{tabular}{|c|c|c|c|c|c|c|c|c|c|c|c|c|}
\hline Laboratory No & 9158 & 9159 & 9160 & 9194 & 9195 & 9196 & 9233 & 9234 & 9235 & 9202 & B & $\mathbf{L}$ \\
\hline $\begin{array}{l}\text { Methane, } \mathrm{CH}_{1} \\
\text { Ethane, } \mathrm{C}_{2} \mathrm{H}_{6} \\
\text { Nitrogen, } \mathrm{N}_{2} \\
\text { Carbon dioxide, } \mathrm{CO}_{2} \\
\text { Oxygen, } \mathrm{O}_{2}\end{array}$ & $\begin{array}{r}87.6 \\
11.7 \\
.7 \\
.0 \\
.0\end{array}$ & $\begin{array}{r}88.5 \\
10.6 \\
.9 \\
.0 \\
.0\end{array}$ & $\begin{array}{r}87.2 \\
11.6 \\
1.2 \\
.0 \\
.0\end{array}$ & $\begin{array}{r}88.2 \\
9.2 \\
1.8 \\
.5 \\
.3\end{array}$ & $\begin{array}{r}96.7 \\
1.8 \\
1.0 \\
.5 \\
.0\end{array}$ & $\begin{array}{r}91.8 \\
6.8 \\
1.4 \\
.0 \\
.0\end{array}$ & $\begin{array}{r}60.8 \\
39.1 \\
.1 \\
.0 \\
.0\end{array}$ & $\begin{array}{r}79.5 \\
19.2 \\
1.3 \\
.0 \\
.0\end{array}$ & $\begin{array}{r}26.3 \\
73.6 \\
.1 \\
.0 \\
.0\end{array}$ & $\begin{array}{r}62.1 \\
37.9 \\
.0 \\
.0 \\
.0\end{array}$ & $\begin{array}{r}86.1 \\
13.4 \\
.5 \\
.0 \\
.0\end{array}$ & $\begin{array}{r}95.2 \\
2.4 \\
2.4 \\
.0 \\
.0\end{array}$ \\
\hline $\begin{array}{l}\text { Total paraffins } \\
\text { Specific gravity (air }=1 \text { ) } \\
\text { British thermal units per } \\
\text { cubic foot of gas at } 0^{\circ} \text { C. } \\
\text { and } 760 \text { millimeters....... }\end{array}$ & $\begin{array}{r}100.0 \\
93.3 \\
.62 \\
1,151\end{array}$ & $\mid \begin{array}{c}100.0 \\
99.1 \\
.61 \\
\\
1,140\end{array}$ & $\begin{array}{c}100.0 \\
98.8 \\
.62 \\
\\
1,144\end{array} \mid$ & $\left|\begin{array}{c}100.0 \\
97.4 \\
.62 \\
\\
1,110\end{array}\right|$ & $\begin{array}{r}100.0 \\
98.5 \\
.57 \\
1,063\end{array}$ & $\left|\begin{array}{r}100.0 \\
98.6 \\
.59 \\
\\
1,105\end{array}\right|$ & $\begin{array}{r}100.0 \\
99.9 \\
.75 \\
1,376\end{array}$ & $\begin{array}{r}100.0 \\
98.7 \\
.66 \\
1,204\end{array}$ & $\begin{array}{r}100.0 \\
99.9 \\
.82 \\
\\
1,650\end{array}$ & $\left|\begin{array}{r}100.0 \\
100.0 \\
.74 \\
1,366\end{array}\right|$ & $\left|\begin{array}{r}100.0 \\
.62 \\
1,166\end{array}\right|$ & 100.0 \\
\hline
\end{tabular}

9158. Fifth sand, Jones No. 1, Plum Township, Allegheny County.

9159. Fifth sand, Stevenagle farm, Plum Township, Allegheny County.

9160. Fifth sand, Lafferty farm, Plum Township, Allegheny County.

9194. Fourth sand, Birchfield farm, Fawn Township, Allegheny County.

9195. Murrysville sand, Kerr farm, Fawn Township, Allegheny County.

9196. Hundred-foot sand, Sarah Gibson farm, Fawn Township, Allegheny County.

9233. Third sand, Gougenour farm, Indiana Township, Allegheny County.

9234. Fifth sand, M. Quinette No. 1, Indiana Township, Allegheny County.

9235. Thirty-foot sand, Robinson farm, Indiana Township, Allegheny County.

9202. Third sand, Wilson No. 1, West Deer Township, Allegheny County.

B. Fifth and Speechley sands, Keasey farm, Winfield Township, Butler County.

L. Oriskany(?) sand, Booth \& Flinn tract, Peoples Natural Gas Co., well No. 1588, Ligonier Township. Westmoreland County. 


\section{CHARACTER OF THE PETROLEUM}

The petroleum produced in the New Kensington quadrangle is representative "Pennsylvania grade," which commands the highest price paid for crude oil. Pennsylvania grade petroleum is composed of a mixture of hydrocarbons, chiefly of the paraffin series, having the general formula $\mathrm{C}_{\mathrm{n}} \mathrm{H}_{2 \mathrm{n}+2}$ which begins with the gas methane $\left(\mathrm{CH}_{4}\right)$ and ranges through various gases, liquids, and solids at least as high as the compound $\mathrm{C}_{35} \mathrm{H}_{72}$. The cyclo hydrocarbons, of which Russian petroleum is largely composed, appear in much smaller proportions in Pennsylvania oil, and the aromatic hydrocarbons, which make up a considerable part of some California varieties, are present only in comparatively minute proportions in Pennsylvania crude oil. Pennsylvania grade oil contains very little sulphur and has a low percentage of oxygen and nitrogen compounds. ${ }^{31}$ It contains a comparatively large proportion of gasoline obtainable by ordinary distillation; lubricating oils are obtained from it by relatively little chemical treatment, and it yields considerable paraffin wax.

Results of analysis of samples of crude oil from the Snee, Hundredfoot, Thirty-foot, Third, Fourth, and Fifth sands in the New Kensington quadrangle are given on pages 69-71. The samples were collected by the writer in the summer of 1917 as the oil issued from the wells before entering the tanks. The samples were sealed at the wells and taken to the laboratory of the Bureau of Mines at Pittsburgh, where they were analyzed by Ernest W. Dean.

The oil was mostly clear amber-colored, though some was greenish, and ranged in specific gravity from 0.794 to 0.811 . The sulphur content of the samples analyzed ranged from 0.06 to 0.16 per cent. The "gasoline and naphtha" content, indicated by the sum of all the fractions distilling at atmospheric pressure below $200^{\circ} \mathrm{C}$. $\left(392^{\circ} \mathrm{F}\right.$.), ranged from 23.7 to 42.1 per cent.

\footnotetext{
u Mabery, C. F., The relations of the chemical composition of petroleum to its genesis and geologic occurrence: Econ. Geology, vol. 11, pp. 511-527, 1916.
} 
Analysis of petroleum from Hundred-foot sand, B. H. Cox farm, Adams Township, Butler County

[Laboratory No. 0038. Specific gravity at $15^{\circ} \mathrm{C} ., 0,795 ; 46.6^{\circ} \mathrm{A}$. P. I. Color, greenish brown, not clear. Per cent of sulphur, 0.07 . Distillation by Bureau of Mines Hempel method]

\section{Air distillation, with fractionating column}

Barometer 743 millimeters. First drop, $28^{\circ} \mathrm{C}$.

\begin{tabular}{|c|c|c|c|c|c|c|c|}
\hline Temperature $\left({ }^{\circ} \mathrm{C}.\right)$ & $\begin{array}{c}\text { Fractions } \\
\text { (per cent } \\
\text { by vol- } \\
\text { ume) }\end{array}$ & $\begin{array}{c}\text { Total dis- } \\
\text { tilled } \\
\text { (per cent } \\
\text { by vol- } \\
\text { ume) }\end{array}$ & $\begin{array}{l}\text { Specific } \\
\text { gravity }\end{array}$ & Temperature $\left({ }^{\circ} \mathrm{C}.\right)$ & $\begin{array}{c}\text { Fractions } \\
\text { (per cent } \\
\text { by vol- } \\
\text { ume) }\end{array}$ & $\begin{array}{c}\text { Total dis- } \\
\text { tilled } \\
\text { (per cent } \\
\text { by vol- } \\
\text { ume) }\end{array}$ & $\begin{array}{l}\text { Specific } \\
\text { gravity }\end{array}$ \\
\hline $\begin{array}{l}\text { Up to } 75 \\
75 \text { to } 100 \\
100 \text { to } 125 \\
125 \text { to } 150 \\
150 \text { to } 175\end{array}$ & $\begin{array}{l}3.6 \\
4.6 \\
8.8 \\
9.0 \\
8.6\end{array}$ & $\begin{array}{r}3.6 \\
8.2 \\
17.0 \\
26.0 \\
34.6\end{array}$ & $\begin{array}{r}0.663 \\
.704 \\
.725 \\
.744 \\
.757\end{array}$ & $\begin{array}{l}175 \text { to } 200 \\
200 \text { to } 225 \\
225 \text { to } 250 \\
250 \text { to } 275 \\
275 \text { to } 300\end{array}$ & $\begin{array}{l}7.5 \\
6.2 \\
6.0 \\
5.1 \\
6.2\end{array}$ & $\begin{array}{l}42.1 \\
48.3 \\
54.3 \\
59.4 \\
65.6\end{array}$ & $\begin{array}{l}0.768 \\
.781 \\
.793 \\
.805 \\
.814\end{array}$ \\
\hline
\end{tabular}

Vacuum distillation, without fractionating column

Pressure 40 millimeters

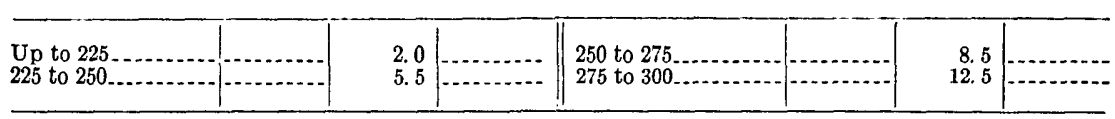

Analysis of petroleum from Hundred-foot sand, Buchter farm well No. 1, West Deer Township, Allegheny County

[ Laboratory No. 0053 . Specific gravity at $15^{\circ} \mathrm{C} ., 0.794 ; 46.8^{\circ} \mathrm{A}$. P. I. Color, greenish yellow. Per cent of sulphur, 0.12. Distillation by Bureau of Mines Hempel method]

Air distillation, with fractionating column

Barometer, 745 millimeters. First drop, $48^{\circ} \mathrm{C}$.

\begin{tabular}{|c|c|c|c|c|c|c|c|}
\hline Temperature $\left({ }^{\circ} \mathrm{C}.\right)$ & $\begin{array}{l}\text { Fractions } \\
\text { (per cent } \\
\text { by } \nabla 0 l- \\
\text { ume) }\end{array}$ & $\begin{array}{c}\text { Total dis- } \\
\text { tilled } \\
\text { (per cent } \\
\text { by vol- } \\
\text { ume) }\end{array}$ & $\begin{array}{l}\text { Specific } \\
\text { gravity }\end{array}$ & Temperature $\left({ }^{\circ} \mathrm{C}.\right)$ & $\begin{array}{l}\text { Fractions } \\
\text { (per cent } \\
\text { by vol- } \\
\text { ume) }\end{array}$ & $\begin{array}{l}\text { Total dis- } \\
\text { tilled } \\
\text { (per cent } \\
\text { by vol- } \\
\text { ume) }\end{array}$ & $\begin{array}{l}\text { Specific } \\
\text { gravity }\end{array}$ \\
\hline $\begin{array}{l}\text { Up to } 75 \\
75 \text { to } 100 \\
100 \text { to } 125 \\
125 \text { to } 150 \ldots \ldots \\
150 \text { to } 175 \ldots \ldots\end{array}$ & $\begin{array}{l}1.0 \\
2.0 \\
5.0 \\
7.9 \\
8.7\end{array}$ & $\begin{array}{r}1.0 \\
3.0 \\
8.0 \\
15.9 \\
24.6\end{array}$ & $\begin{array}{r}0.715 \\
.741 \\
.750\end{array}$ & $\begin{array}{l}175 \text { to } 200 \\
200 \text { to } 225 \ldots \\
225 \text { to } 250 \ldots \\
250 \text { to } 275 \ldots \ldots \\
275 \text { to } 300 \ldots \ldots\end{array}$ & $\begin{array}{r}12.0 \\
10.7 \\
11.0 \\
9.0 \\
8.9\end{array}$ & $\begin{array}{l}36.6 \\
47.3 \\
58.3 \\
67.3 \\
76.2\end{array}$ & $\begin{array}{r}0.767 \\
.779 \\
.791 \\
.804 \\
.814\end{array}$ \\
\hline
\end{tabular}

Vacuum distillation, without fractionating column

Pressure 40 millimeters

\begin{tabular}{|c|c|c|c|c|c|c|c|}
\hline $\begin{array}{l}\text { Up to } 250 \\
250 \text { to } 275\end{array}$ & 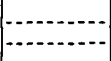 & $\begin{array}{l}3.5 \\
7.5\end{array}$ & 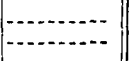 & 275 to $300 \ldots \ldots$ & (n. & 11.5 & $\ldots$ \\
\hline
\end{tabular}


Analysis of petroleum from Thirty-foot sand, Robinson farm, Indiana Township, Allegheny County

|Laboratory No. 0045 . Specific gravity at $15^{\circ} \mathrm{C} ., 0.798 ; 45.9^{\circ}$ A. P. I. Per cent of sulphur, 0.07 . Distillation by Bureau of Mines Hempel method]

Air distillation, with fractionating column

Barometer, 747 millimeters. First drop $30^{\circ} \mathrm{C}$.

\begin{tabular}{|c|c|c|c|c|c|c|c|}
\hline Temperature ( $\left.{ }^{\circ} \mathrm{C}.\right)$ & $\begin{array}{c}\text { Fractions } \\
\text { (per cent } \\
\text { by vol- } \\
\text { ume) }\end{array}$ & $\begin{array}{l}\text { Total dis- } \\
\text { tilled } \\
\text { (per cent } \\
\text { by vol- } \\
\text { ume) }\end{array}$ & $\begin{array}{l}\text { Speciflc } \\
\text { gravity } \\
\end{array}$ & Temperature $\left({ }^{\circ} \mathrm{C}.\right)$ & $\begin{array}{c}\text { Fractions } \\
\text { (per cent } \\
\text { by vol- } \\
\text { ume) }\end{array}$ & $\begin{array}{l}\text { Total dis- } \\
\text { tilled } \\
\text { (per cent } \\
\text { by vol- } \\
\text { ume) }\end{array}$ & $\begin{array}{l}\text { Specific } \\
\text { gravity }\end{array}$ \\
\hline $\begin{array}{l}\text { lip to } 75 \\
75 \text { to } 100 \\
100 \text { to } 125 \\
125 \text { to } 150 \\
150 \text { to } 175\end{array}$ & $\begin{array}{l}5.7 \\
4.2 \\
7.1 \\
5.8 \\
5.9\end{array}$ & $\begin{array}{r}5.7 \\
9.9 \\
17.0 \\
22.8 \\
28.7\end{array}$ & $\begin{array}{r}0.649 \\
.705 \\
.726 \\
.747 \\
.758\end{array}$ & $\begin{array}{l}175 \text { to } 200 \\
200 \text { to } 225 \\
225 \text { to } 250 \ldots \\
250 \text { to } 275 \ldots \\
275 \text { to } 300 \ldots \ldots\end{array}$ & $\begin{array}{l}5.7 \\
5.6 \\
5.6 \\
5.5 \\
7.8\end{array}$ & $\begin{array}{l}34.4 \\
40.0 \\
45.6 \\
51.1 \\
58.9\end{array}$ & $\begin{array}{l}0.771 \\
.782 \\
.792 \\
.806 \\
.813\end{array}$ \\
\hline
\end{tabular}

Vacuum distillation, without fractionating column

Pressure 40 millimeters

\begin{tabular}{|c|c|c|c|c|c|c|c|}
\hline $\begin{array}{l}\mathrm{U} p \text { to } 200 \\
200 \text { to } 225 \\
225 \text { to } 250\end{array}$ & 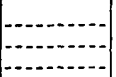 & $\begin{array}{l}1.0 \\
4.5 \\
9.3\end{array}$ & 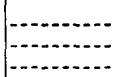 & 250 to $275 \ldots$ & 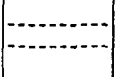 & $\begin{array}{l}14.5 \\
19.2\end{array}$ & (n) \\
\hline
\end{tabular}

Analysis of petroleum from Third sand, Warner farm well No. 4, Ross Township, Allegheny County

[Laboratory No. 0056. Specific gravity at $15^{\circ}$ C., $0.797 ; 46.1^{\circ}$ A. P. I. Color, clear amber. Per cent of sulphur, 0.10 . Distillation by Bureau of Mines Hempel method]

Air distillation, with fractionating column

Barometer, 744 millimeters. First drop $30^{\circ} \mathrm{C}$.

\begin{tabular}{|c|c|c|c|c|c|c|c|}
\hline Temperature $\left({ }^{\circ} \mathrm{C}.\right)$ & $\begin{array}{c}\text { Fractions } \\
\text { (per cent } \\
\text { by vol- } \\
\text { ume) }\end{array}$ & $\begin{array}{l}\text { Total dis- } \\
\text { tilled } \\
\text { (per cent } \\
\text { by vol- } \\
\text { ume) }\end{array}$ & $\begin{array}{l}\text { Specific } \\
\text { gravity }\end{array}$ & Temperature $\left({ }^{\circ} \mathrm{C}.\right)$ & $\begin{array}{c}\text { Fractions } \\
\text { (per cent } \\
\text { by vol- } \\
\text { ume) }\end{array}$ & $\mid \begin{array}{c}\text { Total dis- } \\
\text { tilled } \\
\text { (per cent } \\
\text { by } \nabla 01- \\
\text { ume) }\end{array}$ & $\begin{array}{l}\text { Specific } \\
\text { gravity }\end{array}$ \\
\hline $\begin{array}{l}\text { Up to } 75 \\
75 \text { to } 100 \\
100 \text { to } 125 \\
125 \text { to } 150 \\
150 \text { to } 175\end{array}$ & $\begin{array}{l}1.5 \\
3.6 \\
5.5 \\
6.3 \\
8.4\end{array}$ & $\begin{array}{r}1.5 \\
5.1 \\
10.6 \\
16.9 \\
25.3\end{array}$ & $\begin{array}{r}0.686 \\
.728 \\
.744 \\
.757\end{array}$ & $\begin{array}{l}175 \text { to } 200 \\
200 \text { to } 225 \\
225 \text { to } 250 \\
250 \text { to } 275 \\
275 \text { to } 300\end{array}$ & $\begin{array}{l}6.4 \\
7.9 \\
6.8 \\
6.4 \\
7.6\end{array}$ & $\begin{array}{l}31.7 \\
39.6 \\
46.4 \\
52.8 \\
60.4\end{array}$ & $\begin{array}{l}0.771 \\
.783 \\
.797 \\
.806 \\
.820\end{array}$ \\
\hline
\end{tabular}

Vacuum distillation, without fractionating column

Pressure 40 millimeters

\begin{tabular}{|c|c|c|c|c|c|c|c|}
\hline Up to 250 & 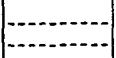 & $\begin{array}{l}1.5 \\
5.5\end{array}$ & 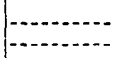 & 275 to 300 & - & 11.0 & $\ldots \ldots$ \\
\hline
\end{tabular}


Analysis of petroleum from Fourth sand, Franke farm, Jefferson Township, Butler County

[Laboratory No. 0057. Specific gravity at $15^{\circ}$ C., $0.804 ; 44.6^{\circ}$ A. P. I. Per cent of sulphur, 0.107. Distillation by Bureau of Mines Hempel method]

Air distillation, with fractionating column

Barometer, 742 millimeters. First drop $35^{\circ} \mathrm{C}$.

\begin{tabular}{|c|c|c|c|c|c|c|c|}
\hline Temperature $\left({ }^{\circ} \mathrm{C}.\right)$ & $\begin{array}{c}\text { Fractions } \\
\text { (per cent } \\
\text { by vol- } \\
\text { ume) }\end{array}$ & $\begin{array}{l}\text { Total dis- } \\
\text { tilled } \\
\text { (per cent } \\
\text { by vol- } \\
\text { ume) }\end{array}$ & $\begin{array}{l}\text { Specific } \\
\text { gravity }\end{array}$ & Temperature $\left({ }^{\circ} \mathrm{C}.\right)$ & $\begin{array}{c}\text { Fractions } \\
\text { (per cent } \\
\text { by vol- } \\
\text { ume) }\end{array}$ & $\mid \begin{array}{c}\text { Total dis- } \\
\text { tilled } \\
\text { (per cent } \\
\text { by vol- } \\
\text { ume) }\end{array}$ & $\begin{array}{l}\text { Specific } \\
\text { gravity }\end{array}$ \\
\hline $\begin{array}{l}\text { Up to } 75 \\
75 \text { to } 100 \\
100 \text { to } 125 \\
125 \text { to } 150 \ldots \ldots \\
150 \text { to } 175 \ldots \ldots\end{array}$ & $\begin{array}{l}1.2 \\
4.0 \\
7.6 \\
7.3 \\
7.2\end{array}$ & $\begin{array}{r}1.2 \\
5.2 \\
12.8 \\
20.1 \\
27.3\end{array}$ & $\begin{array}{r}0.690 \\
.727 \\
.743 \\
.760\end{array}$ & $\begin{array}{l}175 \text { to } 200 \\
200 \text { to } 225 \\
225 \text { to } 250 \\
250 \text { to } 275 \\
275 \text { to } 300\end{array}$ & $\begin{array}{r}6.8 \\
7.2 \\
7.1 \\
6.5 \\
7.5\end{array}$ & $\begin{array}{l}34.1 \\
41.3 \\
48.4 \\
54.9 \\
62.4\end{array}$ & $\begin{array}{r}0.772 \\
.782 \\
.793 \\
.802 \\
.817\end{array}$ \\
\hline
\end{tabular}

Vacuum distillation, without fractionating column

Pressure 40 millimeters

\begin{tabular}{|c|c|c|c|c|c|c|c|}
\hline $\begin{array}{l}\text { Up to } 150 \\
150 \text { to } 175 \\
175 \text { to } 200 \\
200 \text { to } 225\end{array}$ & 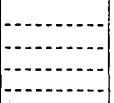 & $\begin{array}{l}0.5 \\
1.4 \\
1.6 \\
2.5\end{array}$ & 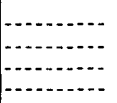 & $\begin{array}{l}225 \text { to } 250 \\
250 \text { to } 275 \\
275 \text { to } 300\end{array}$ & $\left|\begin{array}{|c|}-\ldots+\cdots \\
-\cdots \\
-\cdots\end{array}\right|$ & $\begin{array}{r}6.9 \\
10.5 \\
17.3\end{array}$ & 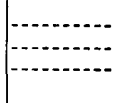 \\
\hline
\end{tabular}

Analysis of petroleum from Fifth sand, George Thompson farm, Fawn Township, Allegheny County

[Laboratory No. 0042 . Specific gravity at $15^{\circ} \mathrm{C} ., 0.808 ; 43.7^{\circ} \mathrm{A}$. P. I. Color, clear amber. Per cent of sulphur, 0.09 . Distillation by Bureau of Mines Hempel method]

Air distillation, with fractionating column

Barometer, 747 millimeters. First drop $25^{\circ} \mathrm{C}$.

\begin{tabular}{|c|c|c|c|c|c|c|c|}
\hline Temperature ( $\left.{ }^{\circ} \mathrm{C}.\right)$ & $\begin{array}{l}\text { Fractions } \\
\text { (per cent } \\
\text { by vol- } \\
\text { ume) }\end{array}$ & $\begin{array}{c}\text { Total dis- } \\
\text { tilled } \\
\text { (per cent } \\
\text { by vol- } \\
\text { ume) }\end{array}$ & $\begin{array}{l}\text { Specific } \\
\text { gravity }\end{array}$ & Temperature ( $\left.{ }^{\circ} \mathrm{C}.\right)$ & $\begin{array}{c}\text { Fractions } \\
\text { (per cent } \\
\text { by vol- } \\
\text { ume) }\end{array}$ & $\begin{array}{c}\text { Total dis- } \\
\text { tilled } \\
\text { (per cent } \\
\text { by vol- } \\
\text { ume) }\end{array}$ & $\begin{array}{l}\text { Specific } \\
\text { gravity }\end{array}$ \\
\hline $\begin{array}{l}\text { Up to } 75 \\
75 \text { to } 100 \\
100 \text { to } 125 \\
125 \text { to } 150 \\
150 \text { to } 175 \ldots\end{array}$ & $\begin{array}{l}2.2 \\
2.4 \\
2.9 \\
4.1 \\
5.0\end{array}$ & $\begin{array}{r}2.2 \\
4.6 \\
7.5 \\
11.6 \\
16.6\end{array}$ & $\begin{array}{r}0.683 \\
.733 \\
.753\end{array}$ & $\begin{array}{l}175 \text { to } 200 \\
200 \text { to } 225 \\
225 \text { to } 250 \\
250 \text { to } 275 \\
275 \text { to } 300\end{array}$ & $\begin{array}{l}7.1 \\
8.2 \\
7.5 \\
7.1 \\
9.5\end{array}$ & $\begin{array}{l}23.7 \\
31.9 \\
39.4 \\
46.5 \\
56.0\end{array}$ & $\begin{array}{r}0.768 \\
.778 \\
.780 \\
.801 \\
.808\end{array}$ \\
\hline
\end{tabular}

Vacuum distillation, without fractionating column

Pressure 40 millimeters

\begin{tabular}{|c|c|c|c|c|c|}
\hline $\begin{array}{l}\text { Up to } 225 \ldots \\
225 \text { to } 250 \ldots\end{array}$ & - & $\begin{array}{l}250 \text { to } 275 \ldots \\
275 \text { to } 300 \ldots \ldots\end{array}$ & $\mid \begin{array}{ll}-2 \\
-1\end{array}$ & $\begin{array}{l}14.0 \\
21.0\end{array}$ & \\
\hline
\end{tabular}

\section{OUTLOOK FOR OIL AND GAS}

In the New Kensington quadrangle the oil and gas sands have been rather thoroughly tested down to and including the Fifth, and it may be expected that future production from these upper sands, by the methods now in use, will continue the decline that for many years has been in progress. In the future as in the past, however, because of the "spotted" occurrence of oil and gas in lenticular sands of variable 
porosity there may be occasional discoveries of small productive areas in the upper sands.

A greater increase in the rate of production that may be obtained from these depleted upper sands is likely to result from improved methods of recovery. In general less than 30 per cent of the original oil content is believed to be recovered by present methods, and the recovery from some sands is estimated to be even as low as 10 per cent, but as a result of the activities of technologists who are working on the problem an increase in the present percentage of recovery may be expected. Greater recovery of oil can be accomplished by increasing the pressure on the sands, by increasing the fluidity of the oil, and by decreasing its surface tension and its adhesion. to rock particles. At the time of the present survey of the New Kensington quadrangle no systematic efforts had been made along these lines. It may be expected, however, that there will be attempts in the not distant future to obtain some of the oil left in the sands by current methods of production. Before beginning improved methods. of extraction, however, a study of subsurface conditions in the chosen areas should be made, including core drilling. This is especially necessary in a region like that under consideration, where production is "spotty" and where the sands are so variable. It is desirable that reasonably large areas be available for experimentation and that there be, if unit operation is not practicable, at least some form of cooperation between operators of contiguous tracts.

The sands below the Fifth that are productive in other areas constitute a reserve of indefinite value in the New Kensington quadrangle. None of these sands have been thoroughly tested in this area, and some have not yet been reached by the drill.

The Speechley sand, lying 800 to 900 feet below the Fifth sand and 2,500 to 2,600 feet below the Upper Freeport coal, is a probable source of future production. It has been found to be gas-bearing in many wells in the quadrangle, but so far as the writer is aware oil has not yet been obtained from this sand in the area here considered. Doubtless it will be thoroughly tested for gas along the axis and upper flanks of the Kellersburg and Amity anticlines. The search for oil however, is more hazardous. As water apparently is not present in the Speechley sand, oil is likely to be found in the lower parts of the folds adjacent to the axes of the synclines. Also, as in the upper sands, both oil and gas have probably accumulated regardless of structure, in irregularly distributed more porous parts of the sand, the discovery of which must be largely a matter of chance: After a new productive area has been discovered extensions of it are more likely to be found in the direction of the strike of the rocks than up or down the dip, because lithologic features are more likely to continue in the direction parallel to the regional structural trends, 
which are believed to be generally parallel to old shore lines. But the distribution of the more porous streaks is irregular, and prospecting can best be done by taking advantage of the experience of each test well.

The so-called Bradford sand, lying some 600 feet below the Speechley in the few places where it has been found in the general vicinity of the New Kensington quadrangle, is not as productive as the Speechley sand. Nevertheless this sand, which is a possible source of future production, doubtless will be further tested. Drilling may also encounter productive stray sands.

The deeper-lying sands that yield oil or gas at one place or another in the Appalachian region are also possible sources of production in this quadrangle. Among the principal formations are (1) the Onondaga, the main source of oil and gas in Kentucky and a source of production in Ontario and New York; (2) the Oriskany group and associated beds from which gas is obtained in New York and Pennsylvania; (3) the Albion sandstone of New York and the Tuscarora quartzite of Pennsylvania, the so-called "Clinton" sand which is the source of large quantities of gas and oil in central Ohio and of gas in New York and which has been the objective of the thus far unsuccessful deep drilling in southwestern Pennsylvania; and (4) the Trenton limestone, possibly the Black River limestone (Ordovician), which yields large quantities of oil and gas in Ohio and Indiana and gas in New York. Because of variations in the thickness of the rocks a close calculation of the depth at which the deep-lying sands may be encountered in the New Kensington quadrangle can not be made. It is estimated, however, that in this area the Oriskany lies about 6,000 feet below the Upper Freeport coal; that the Tuscarora quartzite lies some 2,000 feet deeper, and that the Trenton limestone lies between 10,000 and 11,000 feet beneath the Upper Freeport coal.

$63318-32-6$ 


\section{APPENDIX}

\section{RECORDS OF DEEP WELLS IN AREAS ADJACENT TO THE NEW KENSINGTON QUADRANGLE}

R. A. Geary well (Peoples Natural Gas Co.'s well No. 770), 5 miles northwest of McDonald, Washington County, Pa.

[Top of well 130 feet below Pittsburgh coal. From I. C. White]

\begin{tabular}{|c|c|}
\hline Conemaugh and Allegheny formations: & \\
\hline Unrecorded & $0-450$ \\
\hline Lime $_{-}$ & $450-470$ \\
\hline Slate $_{-}$ & $470-595$ \\
\hline Coal & $595-600$ \\
\hline Unrecorded (water at 600 feet) & $600-734$ \\
\hline Pottsville formation: & \\
\hline Sand (gas at 760 and 912 feet) & 734-950 \\
\hline Mauch Chunk shale and Greenbrier limestone: & \\
\hline Pencil Cave. & $950-953$ \\
\hline Lime & $953-982$ \\
\hline tion: & \\
\hline Sand (gas at 1,052 feet) & $982-1,241$ \\
\hline Unrecorded & $241-1,378$ \\
\hline Sand (gas at 1,379 feet) & $378-1,392$ \\
\hline Unrecorded & $392-1,610$ \\
\hline Sand & $610-1,622$ \\
\hline
\end{tabular}

Catskill, Chemung, Portage, and Hamilton formations:

Unrecorded .................. 1, 622-1, 794

Sand (gas at 1,797 feet) ................. 1, 794-1, 817

Unrecorded...................... 1,817-1,910

Sand (gas at 1,912 feet) ................... 1, 910-1, 925

Unrecorded . . . . . . . . . .

Sand ...................... 1, 968-1, 971

White slate..................... 1, 971-2, 990

Lime.............. 2, $990-3,210$

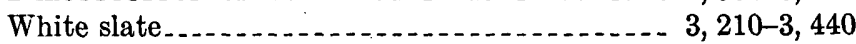

Lime. . . . . . . . . $3,440-3,450$

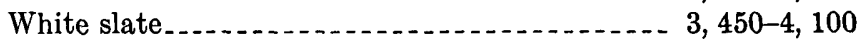

Sand and lime........................ 4, 100-4, 170

White slate................... 4, 170-4, 520

Black slate..................... 4, 520-4, 550

White slate.......................... 4, 550-5, 200

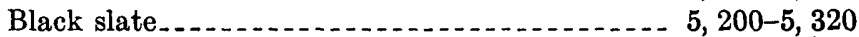

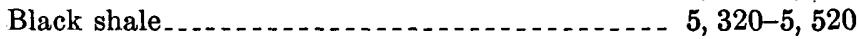

White slate................ 5, 520-5, 660

Limestone ........... 5, 660-5, 680

Black lime . . . . 
Marcellus shale:

Feet

Black slate................. 5, 788-6, 008

Onondaga limestone:

Black lime. . . . . . . . . . . . . . . . . . $008-6,023$

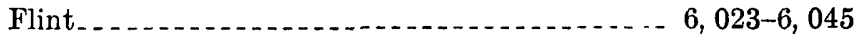

Oriskany group:

Gray sand (water and gas at 6,045 feet) _...... 6, 045-6, 200

Brown sand .................... 6, 200-6, 260

White sand (water at 6,260-6,265 feet) . . . . . 6, 260-6, 270

Brown sand......................... 6, 270-6, 315

Helderberg limestone:

Black lime . . . . 6, 315-6, 395

Sand and black flint................. 6, 395-6, 405

Black lime........................ 6, 405-6, 515

White sand, conglomerate (gas at 6,522 feet;

water at 6,520-6,530 feet) . . . . . . . . . . 6, 515-6, 530

Black limestone...................... 6, 530-6, 610

Gray limestone. . . . . 6, 610-6, 700

Cayuga group (including Salina):

Rock salt . . . . . . . .

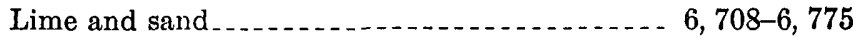

Rock salt. . . . . . . . .

Limestone ......... . . . . . . . 6, 785-6, 830

Rock salt. . . . . . . . . . . 6, 830-6, 840

Lime and sand......................... 6, 840-6, 860

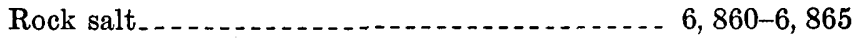

Limestone ............................ 6, 865-6,870

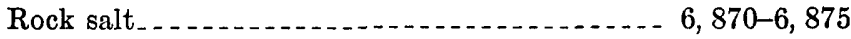

Limestone................ 6, 875-6, 895

Rock salt. . . . . .

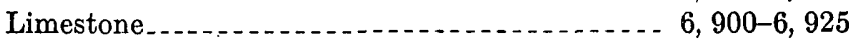

Limestone and sand

Salt and lime shells..................... 7, 020-7, 040

Sand and lime, to bottom.............. 7, 040-7, 248

Booth \& Flinn well No. 9 (Peoples Natural Gas Co.'s well No. 1842), 4 miles northwest of Ligonier, Westmoreland County, Pa. ${ }^{32}$

[Top of well about 200 feet below top of Pocono formation, bottom of well presumbaly in the Cayuga group (Silurian)]

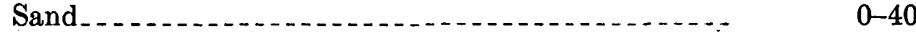

Slate

Sand ................. $60-250$

Slate and shells . . . . . .

Lime. . . . . . . $330-388$

Sand ... . . .

Slate and shells

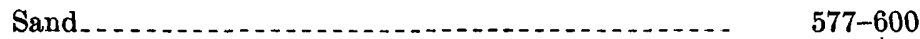

Slate and shells............... $600-637$

Pink rock.......... 637-645

Lime

Red rock

n Record, as reported by the driller, supplied by Peoples Natural Gas Co. 
Feet

Lime

Red rock and shells.

$719-830$

Lime.

$830-880$

Red rock

880-900

Gray shale.

900-920

Sand

920-980

Red rock

980-990

Sand

Red slate

1, 075-1, 080

Sand $1,080-1,104$

White slate

1, 104-1, 135

Hard sand

1, 135-1, 165

Slate

1, 165-1, 260

Slate and shells

$1,260-1,360$

Hard white lime

$1,360-1,432$

White slate

1, 432-1, 445

White lime

$1,445-1,475$

Slate

$1,475-1,760$

Red rock

$1,760-1,780$

Slate and shells

$1,780-1,800$

Sand

$1,800-1,820$

Slate.

1, 820-1, 825

Hard sand.

1, 825-1, 855

Slate and shells.

1, 855-1, 885

Hard sand

1, 885-1, 920

Shells

$1,920-1,985$

White slate

1, 985-2, 025

Slate and shells

$2,025-2,100$

Slate and sand shells

$2,100-2,120$

Sand (show of gas at 2,130 feet)

$2,120-2,135$

Shells

$2,135-2,250$

Lime, dark

$2,250-2,280$

Hard sand.

$2,280-2,380$

Slate

$2,380-2,410$

Sand shells

$2,410-2,413$

Slate

$2,413-2,450$

Shells

$2,450-2,470$

Sand.

$2,470-2,488$

Slate and shells

$2,488-2,495$

Dark sand

$2,495-2,610$

Slate and shells

$2,610-2,670$

Dark lime sand

$2,670-2,728$

Slate

2, 728-2, 732

Sand.

$2,732-2,785$.

Broken sand

$2,785-2,825$

Slate and shells

$2,825-2,910$

Hard sand

$2,910-2,925$

Slate and shells

$2,925-2,948$.

Hard sand

$2,948-2,965$

Slate and shells.

$2,965-2,985$

Hard lime sand

$2,985-3,030$

Slate.

$3,030-3,085$

Hard sand.

$3,085-3,100$ 
Feet

Slate and shells ...................... 3, 100-3, 125

Lime sand ... . . . . .

Slate . . _.

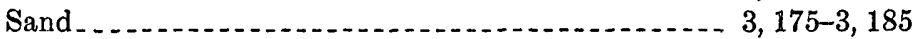

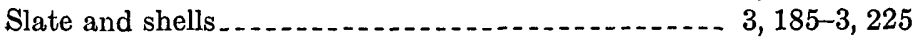

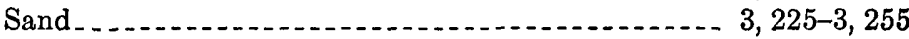

Slate. . . . .

Sand shells_...

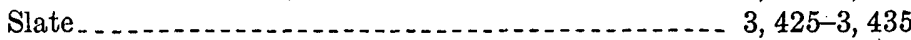

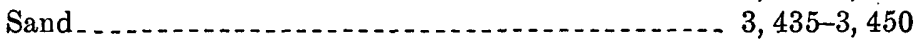

Slate _ _.

Sand . _...

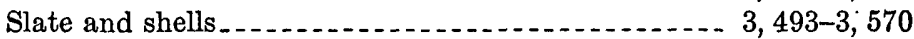

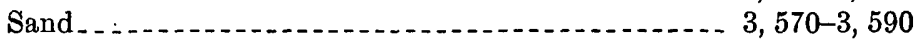

Slate. . .

Slate and shells.................. $3,635-3,725$

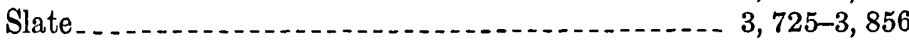

Sandy lime.......

Slate and shells............................. 3, 860-4, 065

Lime and sand.................... 4, 065-4, 090

Slate and shells............................. 4, 090-4, 430

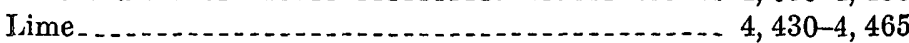

Slate and shells (show of gas at 4,502 feet) . ...... $4,465-4,810$

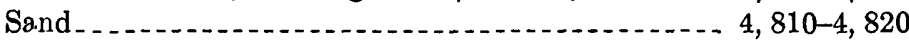

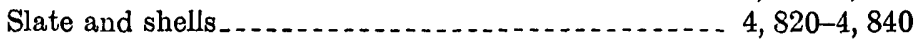

Hard sand............... $4,840-4,852$

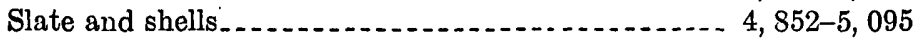

Hard lime............. 5, 095-5, 112

Slate and shells . . . . . . . . . .

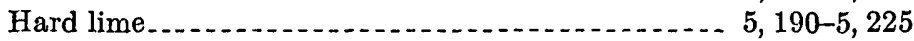

Gray sand............

Hard lime................ 5, 250-5, 270

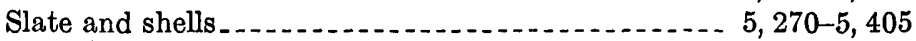

Hard lime........................... 5, 405-5, 440

Slate. . . . . . . . . . . . .

Lime and sand ..................... 5, 445-5, 460

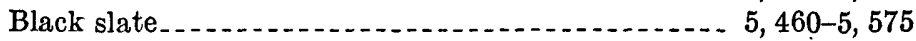

Lime . . . . . . . . . . . . . . . . . . . . . . . 5, 575-5, 715

Slate. . . . .

Shale ...........

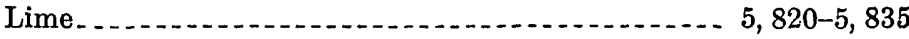

Slate _ . . . . . . . . . . . . . .

Lime . . . . . . . . . . . . . . . . . . . . . . . 5, 950-6, 000

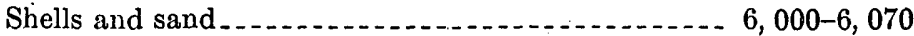

Sand . . . . . . .

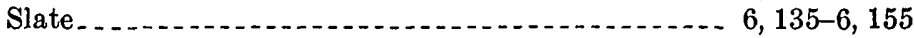

Hard lime ............................. 6, 155-6, 205

Slate . . . . .

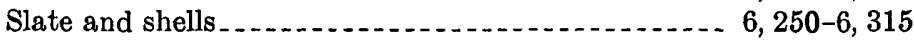

Hard lime..... . . . . . . . . . . . . . . . . 6, 315-6, 330

Slate and shells ........................... 6, 330-6, 390

Slate _... _. .

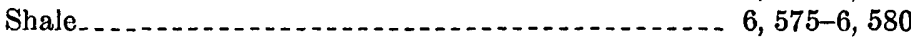




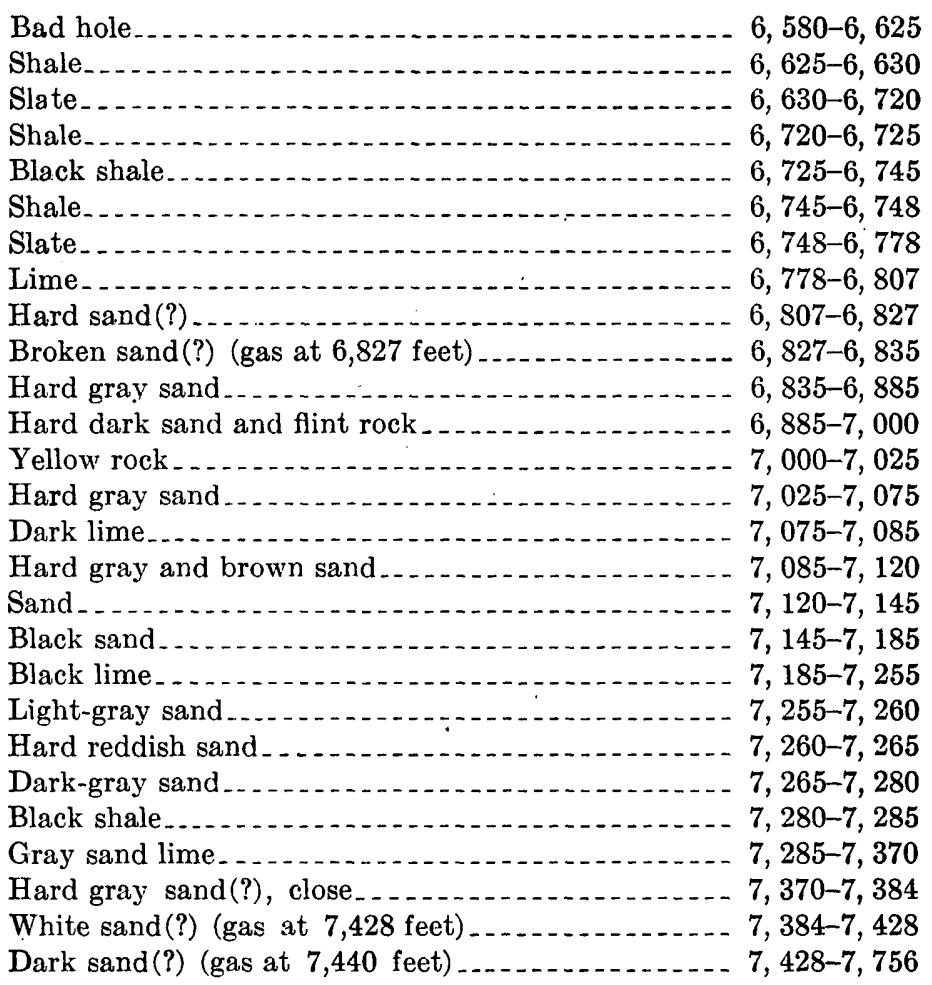

Satisfactory delimitation of the formations in this well can not be made on the basis of the above record, because the names of the rocks as reported by the driller can not be relied upon. For instance, the presence of sand between 7,370 and 7,756 feet is doubtful, because sand at that zone is not indicated by the exposed rocks east of the Allegheny Front. A few tentative correlations, however, are suggested, as follows: The base of the Pocono formation may be at 637 feet; the presence of "pink rock" and "red rock" between 637 and 1,780 feet indicates the Catskill formation; black shale between 6,725 and 6,745 feet presumably is Marcellus shale; "lime" between 6,778 and 6,807 feet suggests the Onondaga limestone; "sand" beginning at 6,807 feet, if it is reported correctly, suggests the Oriskany group, and the gas found at 6,827 feet has been considered to occur in the Oriskany group, though doubt is cast on this correlation by Charles R. Fettke, who states in a personal communication to the writer based on an examination of incomplete cuttings from this well: "From 6,785 to 6,835 feet the cuttings consisted of a cherty limestone practically free from magnesia, which, I believe, represents the Onondaga." Unfortunately, cuttings from this well from which a complete, corrected log could be compiled are not available. Below 5,000 feet the hole is considerably inclined from the vertical, so that the stratigraphic intervals are less than those shown by the record. 


\title{
GENERALIZED SECTIONS OF ROCKS IN MARGINAL AREAS JOF THE PITTSBURGH-HUNTINGTON BASIN
}

\author{
[For location of quadrangles see fig. 1] \\ Columbus quadrangle, Ohio
}

[U. S. Geol. Survey Geol. Atlas, Columbus folio (No. 197), 1915]

Carboniferous:

Exposed rocks

Black hand formation (coarse yellow to red sandstone) - . . . . . .

Cuyahoga formation (fine-grained bluish sandstone alternating with bluish-gray shale) .............

Sunbury shale (fissile, black bituminous shale) ......

Berea sandstone (massive gray to buff sandstone) -.. Unconformity.

Carboniferous or Devonian:

Bedford shale (red and bluish-gray shale and thin

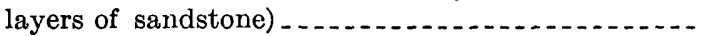
Unconformity.

Devonian:

Ohio shale (bluish-black bituminous shale) . . . . . . 600-650

Olentangy shale (blue calcareous shale) ........... 23-46

Delaware limestone (bluish cherty limestone) ....... 35-40

Columbus limestone (upper part gray semicrystalline limestone; lower part brown magnesian limestone with basal conglomerate)

$105-110$

Unconformity.

Silurian:

Monroe formation (thin-bedded drab dolomite),

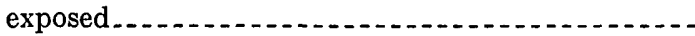

Silurian:

Rocks encountered in drilling

Monroe formation (thin-bedded drab dolomite, gypsum near the base) ...................................

Cedarville and Springfield(?) limestones (gray mag-. nesian limestone) . . . . . . . . . . . . . . . . . . . . .

Osgood(?) shale (bluish to drab shale; limestone lenses) ...

"Clinton" formation (limestone and shale, some of which is red) . . . . . .

"Medina" shale (red and gray shale) ............

Boundary (?).

Ordovician:

Richmond and Maysville formations (calcareous shale and limestone)

Eden shale (dark shale)

Trenton(?) and older limestones (gray impure limestone)

St. Peter sandstone (white and gray calcareous sandstone with some greenish shale) 


\section{Cleveland, Berea, and Euclid quadrangles, Ohio}

[U. S. Geol. Survey Bull. 818, 1931]

Carboniferous:

\section{Exposed rocks}

Pennsylvanian: Sharon conglomerate (white to brown sandstone, basal conglomerate) ........... Unconformity.

Mississippian-

Cuyahoga group:

Meadville shale (blue shale and thin sandstone) . . . . .

Sharpsville sandstone (sandstone, shale partings) ....................................

Orangeville shale (blue-black fissile shale and thin sandstone). (Includes at base a thin representative of Sunbury shale) ....

Berea sandstone (coarse white to brown sandstone)

$30-250$

$25-50$

125

$5-150$

Unconformity.

Carboniferous or Devonian:

Bedford shale (blue and red shale and sandstone) ...

Cleveland shale (dark shale) ....................... Unconformity.

Devonian:

\section{Rocks encountered in drilling}

Chagrin shale (bluish or greenish-gray shale and thin

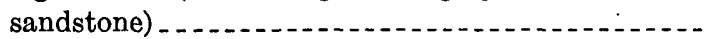

Shales of Portage age (black and gray shale) .......

Shale of Hamilton age (gray calcareous shale) ......

Delaware limestone (blue limestone) ................

Limestone of Onondaga age (gray to brown limestone) .......... . . . .

Lucas dolomite (massive gray dolomite) . . . . . . . . .

Sylvania sandstone...........

Silurian:

Bass Islands dolomite (thin-bedded gray dolomite) -.

Salina formation (limestone, shale, rock salt, gypsum)

Niagara limestone (gray, magnesian limestone) ......

Albion(?) sandstone (limestone, shale, and sandstone) . . . . . . . . . . . .

Silurian or Ordovician:

Queenston(?) shale (red shale)

$615+$

790

80

50

100

$200 \pm$

Ordovician:

Maysville, Edna, Utica, and Trenton probably represented (shale and limestone) 
Niagara Falls quadrangle, New York

[U. S. Geol. Survey Geol. Atlas, Niagara folio (No. 190), 1913]

Devonian:

Exposed rocks

Onondaga limestone (gray, thin-bedded nonmagne-

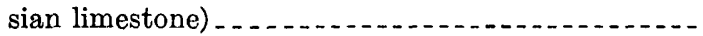

Feet

Unconformity.

Silurian:

Cayuga group-

Cobleskill dolomite (magnesian limestone) ......-

Salina formation (gray magnesian limestone, shale and gypsum)

Niagara group-

Lockport dolomite (gray dolomite and limestone) . . . . . . . .

Clinton formation (shale and limestone) .......

Medina group-

Albion sandstone (gray sandstone, red and gray shale and sandstone, and conrse white sandstone) . . . . . . . . . . . . .

Silurian or Ordovician:

Queenston shale (red argillaceous and sandy șhale) .-

100

440

Silurian or Ordovician:

\section{Rocks encountered in drilling}

Queenston shale (red argillaceous and sandy shale) .Ordovician:

Oswego sandstone

1,200

Lorraine and Utica shales (dark shale)

Trenton and Black River limestones.

Warren quadrangle, Pennsylvania-New York

[U. S. Geol. Survey Geol. Atlas, Warren folio (No. 172), 1910]

Carboniferous:

Exposed rocks

Pottsville formation (sandstone and conglomerate divided by shale and coal)

Feet

Unconformity.

Cuyahoga formation (shale, sandstone, and conglomerate)

Berea sandstone (fossiliferous sandstone) . . . . .... Carboniferous or Devonian:

Knapp formation (conglomerate and shale) ...........

Conewango formation (shale, sandstone, and conglomerate)

Devonian:

Rocks encountered in drilling

Chemung formation (shale and thin sandstone ex-

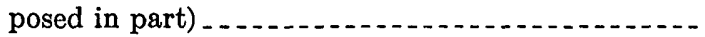

Portage formation (shale and sandstone)

Hamilton shale (dark shale) . . . . . . . . . . . .

Marcellus shale (black shale) 


\section{Somerset and Windber quadrangles, Pennsylvania}

[U. S. Geol. Survey Geol. Atlas, Somerset-Windber foliol (No. 224) (in press)]

Carboniferous:

Pennsylvanian-

Monongahela formation

Fept

Conemaugh formation

Allegheny formation

Pottsville formation

Unconformity.

Mississippian-

Mauch Chunk shale................. 150

Loyalhanna limestone................. 40

Pocono formation. .

\section{Devonian:}

Catskill formation................. 1, 800-2, 000

Chemung formation. $2,000+$

\section{Hollidaysburg and Huntingdon quadrangles, Pennsylvania}

[U. S. Geol. Survey Geol. Atlas, Hollidaysburg-Huntingdon folio (No. 227) (in press)]

Carboniferous:

Pennsylvanian-

Allegheny formation

Feet

Pottsville formation.

$0-200$

$130-300$

Mississippian-

Mauch Chunk formation

$180-1,000$

Loyalhanna limestone

Pocono formation

Upper Devonian:

Catskill formation.

Chemung formation

Portage group-

Brallier shale (gray sandy shale) . . . . . . . 1, 350-1, 800

Harrell shale (black fissile shale) . . . ....... 250

Middle Devonian:

Hamilton formation (greenish and dark shale and sandstone, some limestone)

Marcellus shale (black fissile shale)

Onondaga formation (dark shale and limestone) [so-called "Corniferous"]

Lower Devonian:

Oriskany group-

Ridgeley sandstone (coarse sandstone) ......

Shriver limestone (thin-bedded siliceous limestone)

Helderberg limestone (thick-bedded gray limestone) 
Silurian:

Cayuga group-

Tonoloway limestone (thin-bedded dark limestone)

Wills Creek shale (dove-colored, fissile shale, a little limestone, red and green shale at base)

450

McKenzie formation (thin-bedded limestone, greenish and red shale)

Niagara group-

Clinton formation (greenish shale, some sandstone, thin limestone, and thin beds of iron ore)

Tuscarora quartzite (thick-bedded, white or gray sandstone, equivalent of Albion sandstone Ordovician:

("White Medina") of New York) .............

Juniata formation (red or brown shale or sandstone)

Oswego sandstone (gray sandstone)

Reedsville shale (sandstone, shale, and limestone) _ $\quad 1,000$

Trenton limestone (thin-bedded black limestone.

\section{MEASUREMENTS OF UPPER FREEPORT COAL AND ASSOCIATED} BEDS

New Field No. 1, New Field By-Products Coal Co.

Shale.

[No. 1, pl. 2]

Coal (sample analyzed, laboratory No. in.

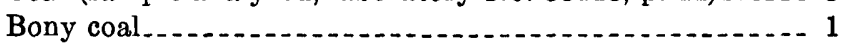

Coal (sample analyzed, laboratory No. 83119, p. 44) _..... 31

Shale............................................ $3 / 2$

Coal.....

Shale.

Coal

Clay.

Oakmont mine, Hillman Coal \& Coke Co.

[No. 2, pl. 2. Composite section, by Charles R. Fettke]

Shale, gray. $\quad$ Ft. In.

Cannel shale............ 110

Coal

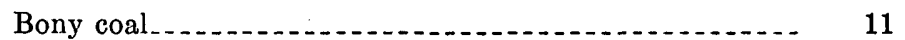

Coal................. 28

Shale, carbonaceous.

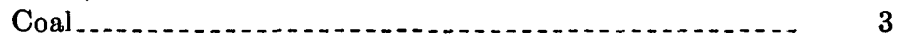

Shale, carbonaceous.

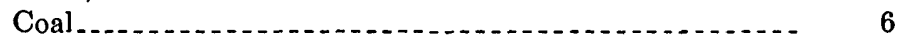




\section{Springdale mine, Allegheny-Pittsburgh Coal Co.}

[No. 3, pl. 2. Samples of upper and lower benches taken by L. D. Woodworth and combined for analysis]

Cannel coal Ft. in.

Coal (sample analyzed, laboratory No. 85877, p. 44) _.... 110

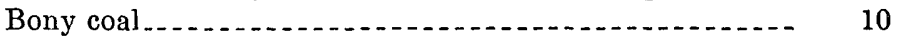

Coal (sample analyzed, laboratory No. 85877) _....... 33

Bony coal

Coal

Bony coal

Coal .............. 7

Harmar mine, Consumers Mining Co.

[No. 4, pl. 2. Samples of upper and lower benches combined for analysis]

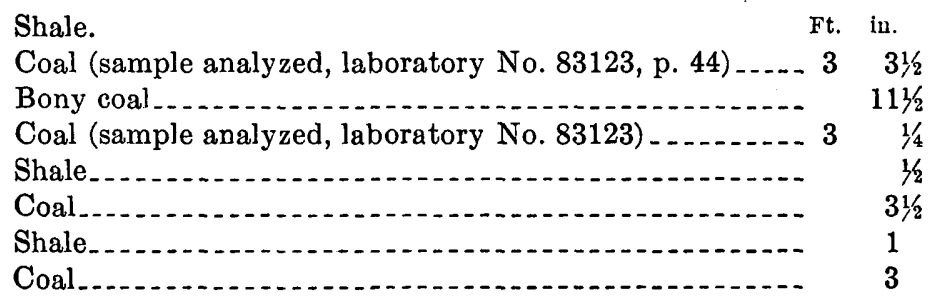

Clay.

Indianola mine, Inland Collieries Co.

Shale.

[No. 5, pl. 2. Face of No. 3, main north]

Coal (sample analyzed, laboratory No. 83121, p. 44) _..._ 31

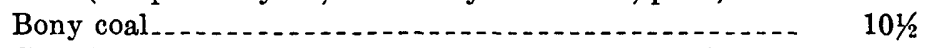

Coal (sample analyzed, laboratory No. 83122 p. 44) _.... 31

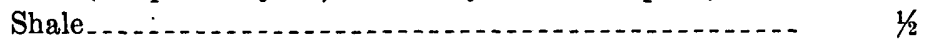

Coal .............

Shale

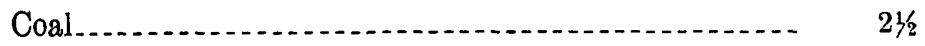

Clay.

Creighton mine, Pittsburgh Plate Glass Co.

[No. 12, pl, 2] Ft. in.

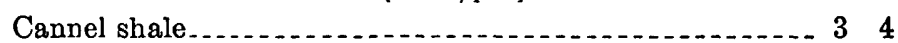

Coal ...

Bony coal......

Coal

Peterson mine, West Tarentum Fuel Co.

Cannel coal_..

Coal streaked with bone and sulphur. . . . . . . . . . 2

Shale

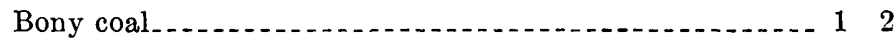

Coal (sample analyzed, laboratory No. 85841, p. 45) _..._- 26

Bony coal............ $1 / 2$

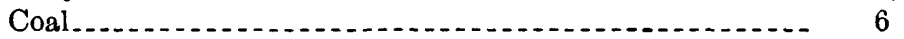


Bessemer No. 2 mine, Republic Iron \& Steel Co.

[No. 14, pl. 2. North entry between west 9 and 10 butt entries to left]

Shale, gray.

Ft. in.

Cannel shale

17

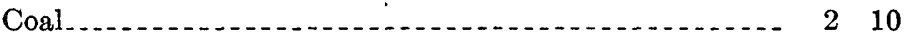

Bony coal...................... 5

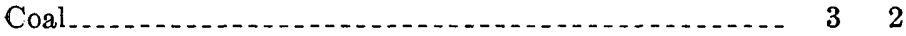

Superior No. 1 mine, Superior Fuel Co.

Shale, gray.

[No. 16, pl. 2]

Shale, carbonaceous. . . . . . .

Cannel shale........................................ 35

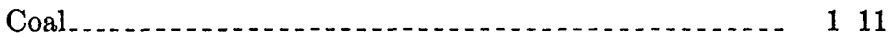

Shale......

Coal ........ 9

Bony coal

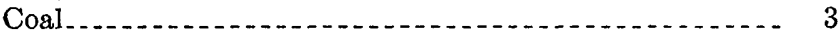

Benjamin mine, Ford Collieries Co.

[No. 17, pl. 2. Eleventh rib, 17th left, south]

Roof, cannel coal.

Coal (sample analyzed, laboratory No. 83114, p. 44) _... 24 ,

Shale and bony coal. . . . . .

Coal (sample analyzed, laboratory No. 83115, p. 44) ..... 2 51/2

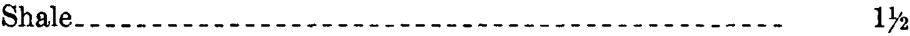

Coal ..........

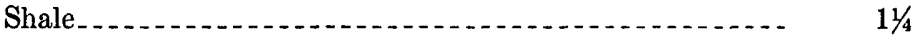

Coal ......... $21 / 4$

Clay.

Berry Mine, Ford Collieries Co.

[No. 18, pl. 2]

Sandstone.

Ft. in.

Cannel shale....................................... 24

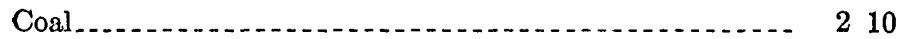

Bony coal

Coal........ 37

Francis mine, Ford Collieries Co.

Sandstone.

[No. 19, pl. 2]

Cannel shale......................................... 36

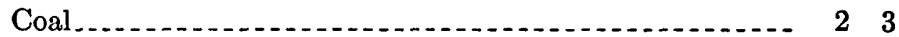

Bony coal .......... 1

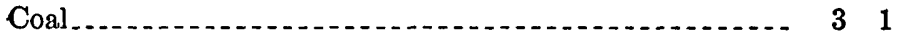




\section{SECTIONS OF HUNDRED-FOOT AND THIRTY-FOOT SANDS, DORSEYVILLE FIELD}

Hodil heirs No. 9, completed August 12, 1918

Hundred-foot sand .............................

Feet

$1,859-1,974$

Sand; oil at 1,927 feet

$1,913-1,933$

Red rock

$1,974-1,989$

Shale and "shells"

$1,989-2,000$

Thirty-foot sand:

Sand, dark, hard

$2,000-2,016^{1 / 2}$

Shale

Sand, white, pebbly; oil pay, gas and water.

Sand, hard, white

Sand, oil, good pay

Sand, hard, white.

$2,016 \frac{1}{2}-2,0191 / 2$

$2,0191 / 2-2,0231 / 2$

$2,0231 / 2-2,042$

$2,042-2,045 \frac{1}{2}$

$2,045 \frac{1}{2}-2,054$

$2,054-2,060$

2, 060-2, 067

Sand, white, very hard

Driller's note.-Hole filled up 500 feet with oil in 24 hours after drilling into second pay sand at 2,042 feet. 1,700 feet of fluid in hole $n 48$ hours after drilling into third pay at 2,054 feet.

Hoeveler No. 3, completed September 3, 1914

Hundred-foot sand
Sand, pay; oil
Thale...
Thirty-foot sand:
$\quad$ Oind, hard first pay
Sand, hard, white
Sand, good; oil
Sand, hard, white
Sand, good; oil

Feet

$1,750-1,855$

$1,789-1,791$

$1,855-1,898$

$1,898-1,918$

$1,918-1,921$

$1,921-1,926$

$1,926-1,9281 / 2$

$1,9281 / 2-1,9291 / 2$

$1,929 \frac{1}{2}-1,933$

Driller's note.-Well showed free oil in pay sand at 1,918-1,921 feet and in pay sand at 1,926-1,928 feet; filled 500 feet with oil. In pay sand at $1,9291 / 2-1,933$ feet well filled up 1,400 feet with oil.

Hodil heirs No. 4, completed September 13, 1913 Feet

Hundred-foot sand . . .............................. 1, 805-1, 905

Broken sand ............................... 1, 805-1, 824

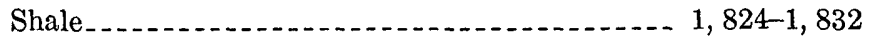

Sand; oil at 1,833-1,838 feet................ 1, 832-1, 842

Sand, hard, white........................ 1, 842-1, 867

Shale and "shells" ........................ 1, 867-1, 890

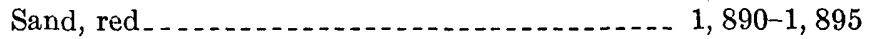

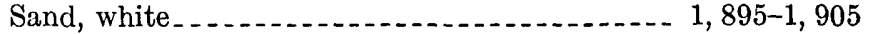

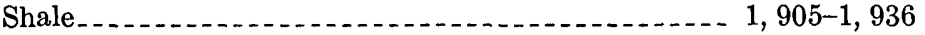

Thirty-foot sand:

Sand with pebbles; gas at 1,940 feet_..._..... 1, 936-1,940

Sand, hard, white ...................... 1, 940-1, 955

Sand, oil pay _............... 1, 955-1, 959

Sand, hard, white $\ldots \ldots \ldots \ldots$ 1, 959-1, 981

Sand, oil pay . . . . . . . . .

Sand, hard, white . 
Hodil heirs No. 6, completed May 8, 1915

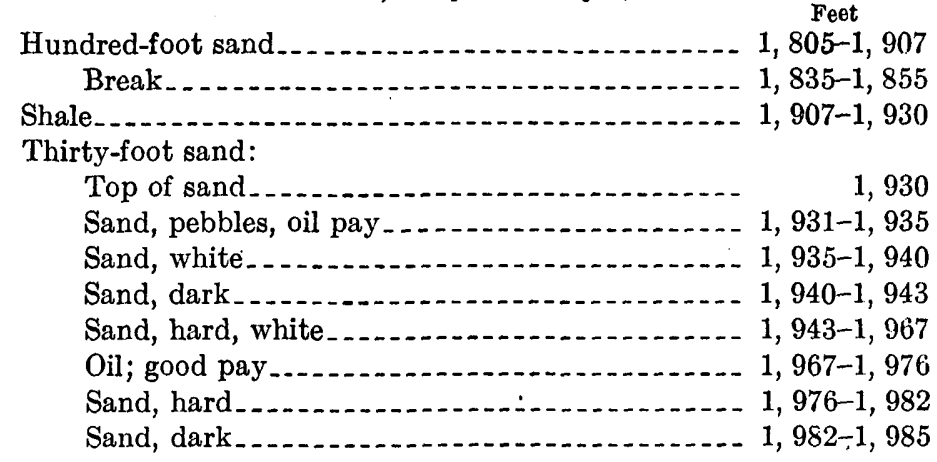

Hass No. 3, completed January 20, 1916

Hundred-foot sand; showing of oil at 1,810 feet..... 1, 745-1,850

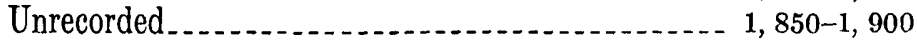

Thirty-foot sand:

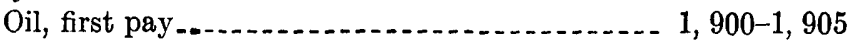

Sand, hard, white ......................... 1, 905-1, 910

Sand, dark, broken ......................... 1, 910-1, 920

Sand, hard, white.......................... 1, 920-1, 929

Oil, second pay ........................ 1, 929-1,932

Sand, hard, white........................ 1, 932-1, 939

Sand, red, broken ........................ 1, 939-1, 943

Shale_................... 1, 943-1, 944

Hass No. 5, completed May 6, 1916

Hundred-foot sand.

Feet

Unrecorded............................. 1, 861-1, 906 $1 / 2$

Thirty-foot sand:

Sand, hard, white

Sand, little oil, first pay ................ 1,910-1,912

Sand, hard, white........................ 1, $912-1,939$

Sand, oil, second pay ................... 1, 1,939-1,947

Sand . . . . .

Bottom of hole.......................... 1950

W. J. Robinson No. 1, completed Seplember 7, 1915

Hundred-foot sand.

Feet

Break . . . . . . . . . . .

Sand, white; showing of oil at 1,842 feet.....

Break

$1,812-1,914$

$1,830-1,840$

$1,840-1,863$

$1,863-1,890$

Sand, dark . . . . . . . . .

Unrecorded............................. 1, 914-1,953

Thirty-foot sand:

Sand, oil and water, first pay _............. 1, 953-1, 957

Sand, hard, white ..................... 1, 957-1, 962

Shale........................... 1, 962-1, 964

Sand, very hard, white ................. 1, 964-1, 977

Sand, good; oil pay ...................... 1, 977-1, 993

Driller's note.-May 4, 1916, well shot with 16 quarts from 1,981 to 1,993 feet and responded by flowing 150 barrels the first 24 hours. 
W. J. Robinson No. 2, completed October 18, 1915

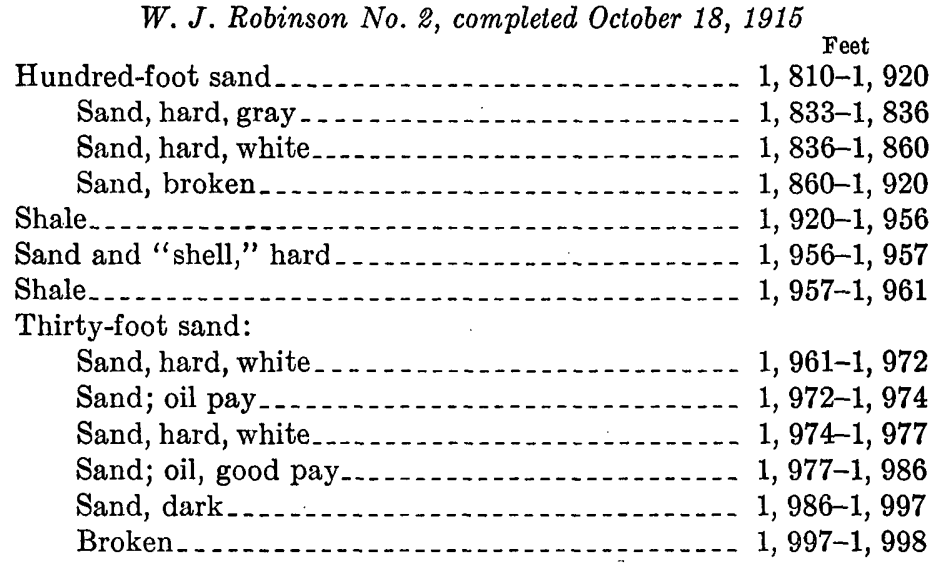

Driller's note.-Drilled into second pay at 1,977 feet and when drilled to 1,982 feet well flowed 35 barrels in 50 minutes and continued at 18 barrels per hour for 3 hours. When drilled to $1,9851 / 2$ feet well flowed steadily at 60 barrels per hour for 8 hours and produced 1,017 barrels in 24 hours. April 17, 1916, well shot with 12 quarts from 1,976 to 1,986 feet and responded by flowing 200 barrels the following 24 hours.

W. J. Robinson No. S, completed October 1, 1915

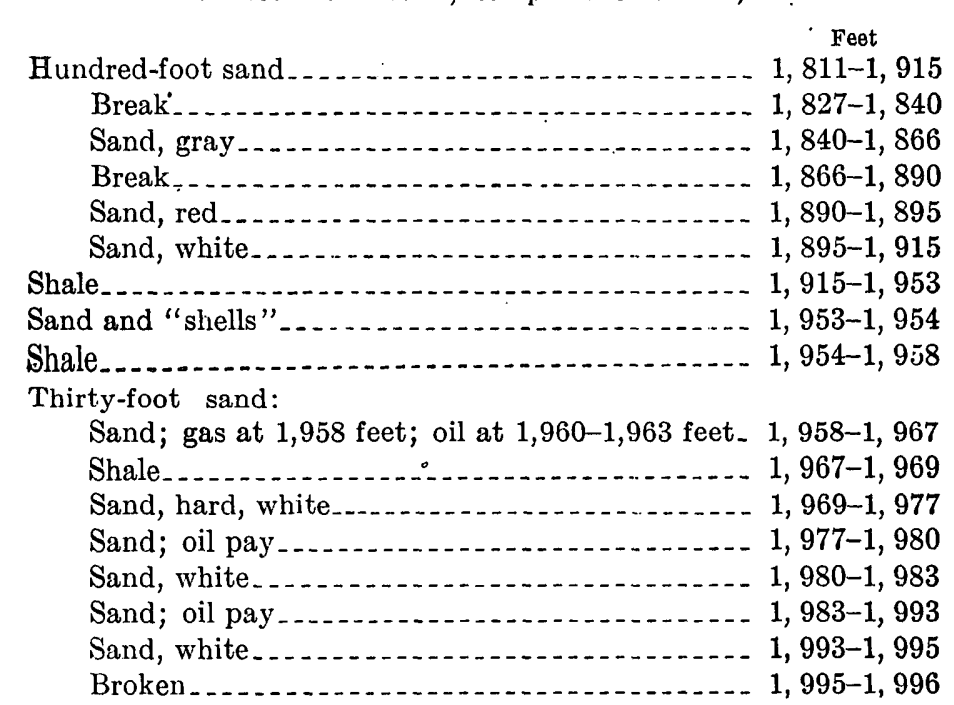

Driller's note.-Well flowed 200 barrels first 24 hours after drilling to depth of 1,989 feet. Well shot with 16 quarts from 1,979 to 1,989 feet and responded by flowing 75 barrels the following 24 hours. 
W. J. Robinson No. 4, completed November 29, 1915

Feet
Hundred-foot sand
Sand and "shells"
Shale._.
Thirty-foot sand:
$\quad$ Sand, good.
$\quad$ Sand, white.....
$\quad$ Sand; oil, good pay.

Driller's note.-Stopped drilling in good pay sand at 1,988 feet, being 17 feet in second pay. On November 25, 1915, at 1,977 feet, well made a 40-barrel flow. At depth of 1,981 feet, or 36 feet in sand, well flowed at the rate of 10 barrels per hour. At depth of 1,983 feet, or 38 feet in sand, well flowed at the rate of 35 barrels per hour. Well's largest production for 24 hours was 557 barrels.

\section{W. J. Robinson No. 5, completed January, 1916}

Hundred-foot sand; oil and water at 1,805 feet.... 1, 750-1, 860

Unrecorded................................. 1,860-1,905

Thirty-foot sand:

Sand; oil at 1,905-1,910 feet.............. 1,905-1, 914

Shale.................................. 1, 914-1, 916

Sand, hard, white.......... 1, 916-1, 928

Bottom of hole................... 1,931

W. J. Robinson No. 6, completed February 17, 1916

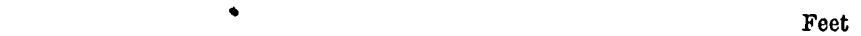

Hundred-foot sand . . . . . . . . . . . . . . . . . . 1, 683-1, 805

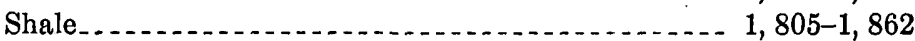

Sand and "shells" ............................. 1, 862-1, 863

Shale...... . . . . . . . . . . $1,863-1,868$

Thirty-foot sand:

Sand; oil, first pay

Sand, hard, white ....................... 1, 873-1, 887

Sand; oil, second pay ...................... 1, 887-1, 890

Sand, hard, white........................ 1, 890-1,896

Sand; oil, third pay ....................... 1, 896-1, 905

Driller's note.-May 10, 1916, well shot with 16 quarts nitroglycerin from 1,895 to 1,905 feet and responded by flowing 150 barrels of oil the ensuing 24 hours. 63318-32-7 


\section{RECORDS OF WELLS IN THE NEW KENSINGTON QUADRANGLE}

Partial records of wells drilled for oil and gas

Adams Township, Butler County

\begin{tabular}{|c|c|c|c|c|c|c|}
\hline \multirow{2}{*}{ Farm } & \multirow{2}{*}{ No. } & \multirow{2}{*}{ Owner of well } & \multirow{2}{*}{$\begin{array}{c}\text { Alti- } \\
\text { tude of } \\
\text { casing } \\
\text { head } \\
\text { above } \\
\text { sea level } \\
\text { (feet) }\end{array}$} & \multicolumn{2}{|c|}{ Oil and gas sands } & \multirow[b]{2}{*}{ Remarks } \\
\hline & & & & Name of sand & $\begin{array}{l}\text { Depth } \\
\text { (feet) }\end{array}$ & \\
\hline Nicholas............ & 1 & Nicholas heirs...-. & 1,179 & Hundred-foot . & $1,431-(?)$ & $\begin{array}{l}\text { First pay, 1,453-1,463 } \\
\text { feet; "break," 1,463- } \\
\text { 1,478 feet; second pay, } \\
\text { 1,478-1,485 feet. Ini- } \\
\text { tial production, 1917, } \\
48 \text { barrels. }\end{array}$ \\
\hline W. W. Rathbun. & 1 & $\begin{array}{l}\text { American Natur- } \\
\text { al Gas Co. }\end{array}$ & 1,186 & Thirty-foot...- & $\begin{array}{l}1,542-1,645 \\
1,657-1,696\end{array}$ & $\begin{array}{l}\text { Gas } 8 \text { feet below top of } \\
\text { Thirty-foot. }\end{array}$ \\
\hline T. W. Hays....... & 2 & Robert Marshall. & 1,087 & $\begin{array}{l}\text { Murrysville--.- } \\
\text { Mundred-foot. } \\
\text { Thirty-foot...- }\end{array}$ & $\begin{array}{l}1,819-1,833 \\
1,325-1,425 \\
1,455-1,564 \\
1,581-1,602\end{array}$ & $\begin{array}{l}\text { Water at } 1,350 \text { feet. } \\
\text { Gas at } 1,587 \text { feet; oil at } \\
1,592, \text { f } \theta \text { ot; s sand } \\
\text { "poor." }\end{array}$ \\
\hline H. B. Rea & 1 & do & 1,096 & $\begin{array}{l}\text { Murrysville.-- } \\
\text { Hundred-foot } \\
\text { Thirty-foot...- }\end{array}$ & $\begin{array}{r}1,265-1,364 \\
1,427-1,529 \\
1,5461 / 2- \\
1,564\end{array}$ & $\begin{array}{l}\text { Gas at } 1,553 \text { feet; oil at } \\
1,558 \text { feet. }\end{array}$ \\
\hline
\end{tabular}

Middlesex Township, Butler County

\begin{tabular}{|c|c|c|c|c|c|c|}
\hline W.R.Thompson. & -.. & M. A. Campbell- & 1,131 & $\begin{array}{l}\text { Murrysville... } \\
\text { Hundred-foot } \\
\text { Thirty-foot.... } \\
\text { Snee- } \\
\text { Boulder.......... } \\
\text { Third........... }\end{array}$ & $\begin{array}{l}1,250-1,349 \\
1,397-1,459 \\
1,562-1,576 \\
1,615-1,645 \\
1,666-1,678 \\
1,709-1,712\end{array}$ & Pay at $1,417-1,427$ feot. \\
\hline J. A. Hays........ & 1 & $\begin{array}{l}\text { United Natural } \\
\text { Gas Co. }\end{array}$ & $1 ; 072$ & Murrysville--- & $1,280-1,378$ & $\begin{array}{l}\text { Much water at } 1,305 \\
\text { feet. }\end{array}$ \\
\hline Mary Kyle......... & 2 & Jacob Morris..... & 1,245 & $\begin{array}{l}\text { Hundred-foot. } \\
\text { Third.......... }\end{array}$ & $\begin{array}{l}1,560-1,710 \\
1,660-1,710 \\
1,910-1,927\end{array}$ & $\begin{array}{l}\text { Oil at } 1,912 \text { feet; } 17 \text { feet } \\
\text { of good sand. }\end{array}$ \\
\hline Richard Marshall & 1 & S. Harbison...... & 1,224 & $\begin{array}{l}\text { Murrysville... } \\
\text { Hundred-foot } \\
\text { Thirty-foot... } \\
\text { Snee. } \\
\text { Boulder. } \\
\text { Third. }\end{array}$ & $\begin{array}{l}1,478-1,550 \\
1,615-1,722 \\
1,760-1,790 \\
1,820-1,840 \\
1,877-1,888 \\
1,908-1,927\end{array}$ & First oil at 1,909 feet; \\
\hline Irons... & $\ldots$ & Jacob Morris..... & 1,169 & $\begin{array}{l}\text { Hundred-foot. } \\
\text { Third. }\end{array}$ & $\begin{array}{l}1,485- \\
1,811-1\end{array}$ & \\
\hline
\end{tabular}

Clinton Township, Butler County

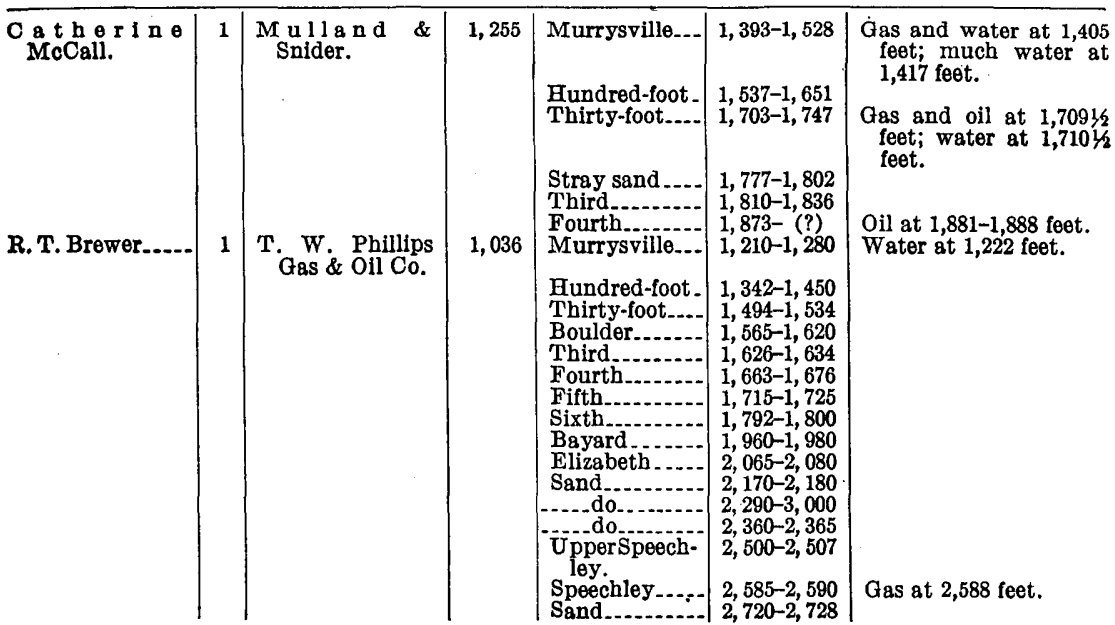


Partial records of wells drilled for oil and gas-Continued

Clinton Township, Butler County-Continued

\begin{tabular}{|c|c|c|c|c|c|c|}
\hline \multirow[b]{2}{*}{ Farm } & \multirow[b]{2}{*}{ No. } & \multirow[b]{2}{*}{ Owner of well } & \multirow{2}{*}{$\begin{array}{c}\text { Alti- } \\
\text { tude of } \\
\text { casing } \\
\text { head } \\
\text { above } \\
\text { sea level } \\
\text { (feet) }\end{array}$} & \multicolumn{2}{|c|}{ Oil and gas sands } & \multirow[b]{2}{*}{ Remarks } \\
\hline & & & & Name of sand & $\begin{array}{c}\text { Depth } \\
\text { (feet) }\end{array}$ & \\
\hline $\begin{array}{l}\text { Charles Ander- } \\
\text { son. }\end{array}$ & $\cdots$ & $\begin{array}{l}\text { A mar i c a n } \\
\text { Natural } \\
\text { Co. }\end{array}$ & $-\cdots+\cdots$ & $\begin{array}{l}\text { Murrysville... } \\
\text { Hundred-foot. } \\
\text { Boulder.-...- } \\
\text { Third, Fourth, } \\
\text { and Fifth. } \\
\text { Speechley..... }\end{array}$ & $\begin{array}{l}1,300-1,385 \\
1,400-1,495 \\
1,610-1,630 \\
1,710-1,844 \\
2,650-2,690\end{array}$ & $\begin{array}{l}\text { Shelly and hard; gas at } \\
1,827 \text { feet. } \\
\text { Gas at } 2,661 \text { feet. }\end{array}$ \\
\hline
\end{tabular}

Buffalo Township, Butler County

\begin{tabular}{|c|c|c|c|c|c|c|}
\hline Ed. Ohl & 1 & $\begin{array}{l}\text { A matural } \underset{\text { Gas }}{\text { matura }} \\
\text { Co. }\end{array}$ & 1,113 & 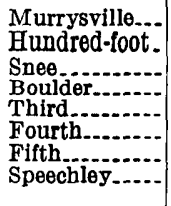 & $\begin{array}{l}1,375-1,465 \\
1,500-1,600 \\
1,660-1,680 \\
1,706-1,721 \\
1,765-1,805 \\
1,830-1,855 \\
1,855-1,909 \\
2,728-2,808\end{array}$ & $\begin{array}{l}\text { Water at } 1,400 \text { foet. } \\
\text { Gas at } 1,527 \text { feot. } \\
\text { Hard and barren. } \\
\text { Gas at } 1,897 \text { feet. } \\
\text { Gas at } 2,731 \text { and } 2,761 \\
\text { feet. }\end{array}$ \\
\hline Fannie Elliott.... & -.. & do & 1,197 & 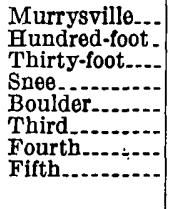 & $\begin{array}{l}1,450-1,540 \\
1,540-1,630 \\
1,658-1,688 \\
1,705-1,725 \\
1,740-1,755 \\
1,800-1,860 \\
1,875-1,893 \\
1,948-1,968\end{array}$ & $\begin{array}{l}\text { "Broken." } \\
\text { White and hard. } \\
\text { Gas at } 1,950 \text { feet; sand } \\
\text { "very nice." }\end{array}$ \\
\hline
\end{tabular}

Fawn Township, Allegheny County

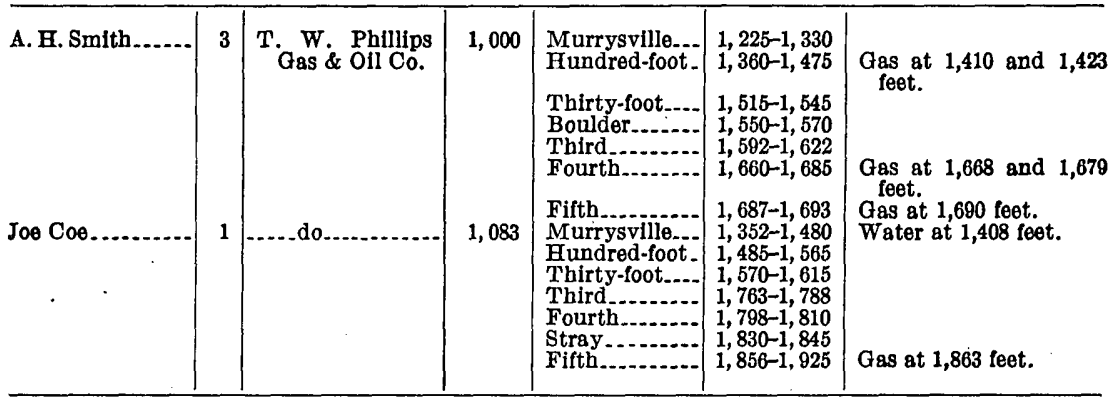

East Deer Township, Allegheny County

\begin{tabular}{|c|c|c|c|c|c|c|}
\hline $\begin{array}{c}\text { R. \& G. Fair- } \\
\text { chlld. }\end{array}$ & 2 & $\begin{array}{l}\text { American Natu- } \\
\text { ral Gas Co. }\end{array}$ & 1,225 & $\begin{array}{l}\text { Murrysville-} \\
\text { Hundred-foot- } \\
\text { Thirty-foot... } \\
\text { Snee-} \\
\text { Boulder. } \\
\text { Stray } \\
\text { Third } \\
\text { Fourth } \\
\text { Fifth }\end{array}$ & $\begin{array}{l}1,664-1,724 \\
1,790-1,916 \\
1,944-1,980 \\
1,994-2,010 \\
2,020-2,060 \\
2,065-2,076 \\
2,078-2,135 \\
2,136-2,155 \\
2,188-2,221\end{array}$ & $\begin{array}{l}\text { Water at 1,670 feet. } \\
\text { Very hard. } \\
\text { Do. } \\
\text { Not very hard. } \\
\text { "Cood-looking" sand. } \\
\text { First pay, 2,202 feet, soft } \\
\text { and pebbly. Second } \\
\text { pay, 2,208 feet. Very } \\
\text { hard sand between } \\
\text { second and third pays. } \\
\text { Third pay, 2,201 feot. }\end{array}$ \\
\hline
\end{tabular}


Partial records of wells drilled for oil and gas-Continued

East Deer Township, Allegheny County-Continued

\begin{tabular}{|c|c|c|c|c|c|c|}
\hline \multirow{2}{*}{ Farm } & \multirow{2}{*}{ No. } & \multirow{2}{*}{ Owner of well } & \multirow{2}{*}{$\begin{array}{c}\text { Alti- } \\
\text { tude of } \\
\text { casing } \\
\text { head } \\
\text { above } \\
\text { sea level } \\
\text { (feet) }\end{array}$} & \multicolumn{2}{|c|}{ Oil and gas sands } & \multirow{2}{*}{ Remarks } \\
\hline & & & & Name of sand & $\begin{array}{l}\text { Depth } \\
\text { (feet) }\end{array}$ & \\
\hline Pete Poecher..... & 1 & $\begin{array}{l}\text { American Natu- } \\
\text { ral Gas Co. }\end{array}$ & 802 & 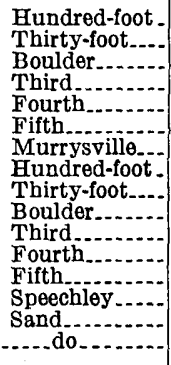 & $\begin{array}{l}1,285-1,380 \\
1,400-1,470 \\
1,518-1,534 \\
1,567-1,580 \\
1,637-1,645 \\
1,674-1,691 \\
1,165-1,250 \\
1,305-1,408 \\
1,410-1,465 \\
1,472-1,487 \\
1,540-1,599 \\
1,625-1,665 \\
1,714-1,746 \\
2,491-2,571 \\
2,620-2,632 \\
2,875-2,890\end{array}$ & $\begin{array}{l}\text { Oil and gas at } 11,367 \text { feet. } \\
\text { Water at } 1,450 \text { feet. } \\
\text { Gas; } 8 \mathrm{at} 1,519 \text { feet. } \\
\text { Gas at 1,571 feet. } \\
\text { Gas at } 1,676 \text { feet. } \\
\text { Water at } 1,350 \text { feet. } \\
\text { Gas at } 1,646 \text { feet. }\end{array}$ \\
\hline
\end{tabular}

West Deer Township, Allegheny County

\begin{tabular}{|c|c|c|c|c|c|c|}
\hline T. Ferguson...... & 1 & $\begin{array}{l}\text { Vollant Oil \& } \\
\text { Gas Co. }\end{array}$ & 1,067 & $\begin{array}{l}\text { Murrysville.. } \\
\text { Hundred-foot. } \\
\text { Thirty-foot.... } \\
\text { Snee_......... } \\
\text { Boulder...... } \\
\text { Third......... }\end{array}$ & $\begin{array}{l}1,307-1,357 \\
1,458-1,552 \\
1,595-1,640 \\
1,665-1,685 \\
1,723-1,756 \\
1,757-1,772\end{array}$ & $\begin{array}{c}\text { Initial production, } 35 \\
\text { barrels. Pumped } 8 \\
\text { years. }\end{array}$ \\
\hline Do & 2 & . do do............. & 1,091 & $\begin{array}{l}\text { Murrysville... } \\
\text { Hundred-foot. } \\
\text { Thirty-foot...- } \\
\text { Snee. } \\
\text { Boulder......... } \\
\text { Third.......... }\end{array}$ & $\begin{array}{l}1,316-1,371 \\
1,452-1,642 \\
1,598-1,644 \\
1,660-1,675 \\
1,675-1,715 \\
1,781-(?)\end{array}$ & $\begin{array}{l}\text { Oil at } 1,796-1,800 \text { feet. } \\
\text { Initial production } 40 \\
\text { barrels. Pumped } 7 \\
\text { years. Watered out. }\end{array}$ \\
\hline J. Scott & 2 & $\begin{array}{l}\text { T. P. Phillips } \\
\text { Gas \& Oil Co. }\end{array}$ & 1,037 & $\begin{array}{l}\text { Murrysville.-- } \\
\text { Hundred-foot. } \\
\text { Thirty-foot.... } \\
\text { Boulder....... } \\
\text { Third } \\
\text { Fourth...........- }\end{array}$ & $\begin{array}{l}1,312-1,380 \\
1,430-1,544 \\
1,578-1,608 \\
1,650-1,680 \\
1,682-1,714 \\
1,752-1,778\end{array}$ & $\begin{array}{l}\text { First pay, } 1,75316- \\
1,7561 / 2 \text { feet; second } \\
\text { pay, 1,760-1,770 feet. } \\
\text { Initial production, } \\
150-200 \text { barrels. }\end{array}$ \\
\hline Thomas Marshall & 4 & ....do do & 1,111 & $\begin{array}{l}\text { Murrysville } \\
\text { Hundred-foot. } \\
\text { Thirty-foot.... } \\
\text { Snee__........ } \\
\text { Boulder........ } \\
\text { Fourth }\end{array}$ & $\begin{array}{l}1,315-1,400 \\
1,465-1,580 \\
1,612-1,645 \\
1,670-1,678 \\
1,682-1,755 \\
1,777-1,809\end{array}$ & $\begin{array}{l}\text { Water at } 1,350 \text { feet. } \\
\text { Very hard." } \\
\text { Hard and "close." } \\
\text { Very hard. } \\
\text { Oil at 1,802-1,809 feet. } \\
\text { Initial production } 20 \\
\text { barrels. }\end{array}$ \\
\hline Dave-Scott_....... & 5 & ...._do............. & 1,107 & $\begin{array}{l}\text { Murrysville... } \\
\text { Hundred-foot. } \\
\text { Thirty-foot.... } \\
\text { Snee_........... } \\
\text { Third } \\
\text { Fourth........ }\end{array}$ & $\begin{array}{l}1,345-1,412 \\
1,480-1,580 \\
1,630-(?) \\
1,692-(?) \\
1,730-1,760 \\
1,789-(?)\end{array}$ & $\begin{array}{l}\text { Oil at } 1,790 \text { feet; oil at } \\
1,797 \text { feet. Initial } \\
\text { production, } 1,000 \text { bary } \\
\text { rels. Started drilling } \\
\text { at } 1,910 \text { feet; aban- } \\
\text { doned at } 1,918 \text { feet. }\end{array}$ \\
\hline $\begin{array}{l}\text { Edison Canning } \\
\text { estate. }\end{array}$ & 2 & $\begin{array}{l}\text { American Natu- } \\
\text { ral Gas Co. }\end{array}$ & 1,072 & 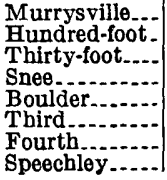 & $\begin{array}{l}1,265-1,345 \\
1,403-1,513 \\
1,537-1,576 \\
1,602-1,619 \\
1,622-1,653 \\
1,703-1,723 \\
-2,552-2,587\end{array}$ & $\begin{array}{l}\text { "No good." } \\
\text { Do. } \\
\text { Absent. } \\
\text { Gas at } 2,578-2,583 \text { feet. }\end{array}$ \\
\hline
\end{tabular}


Partial records of wells drilled for oil and gas-Continued

West Deer Township, Allegheny County-Continued

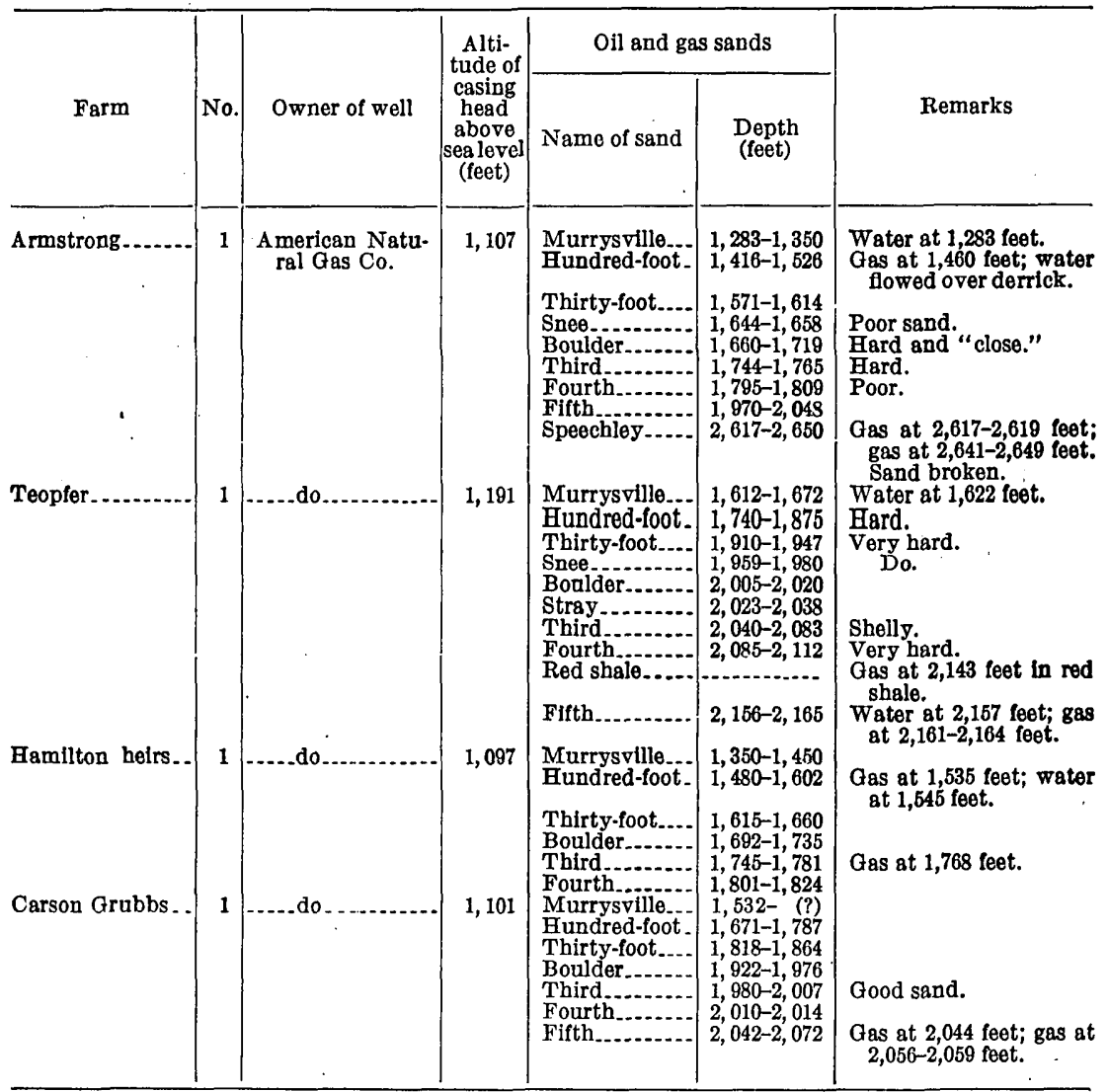

Richland Township, Allegheny County

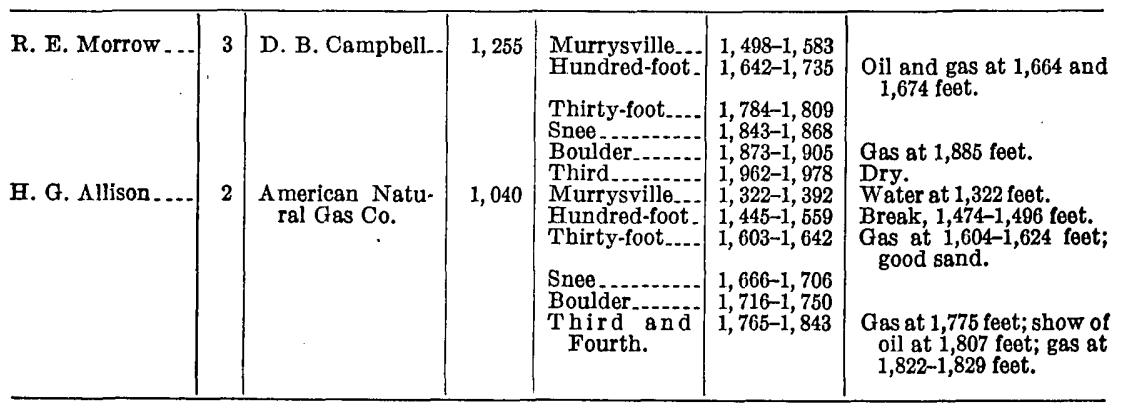

Pine Township, Allegheny County

\begin{tabular}{|c|c|c|c|c|c|c|}
\hline J. N. Bill , ......... & 3 & $\begin{array}{l}\text { Hartle Oil \& Gas } \\
\text { Co. }\end{array}$ & 1,176 & $\begin{array}{l}\text { Murrysville... } \\
\text { Hundred-foot. } \\
\text { Thirty-foot... } \\
\text { Sand } \\
\text { Third } \\
\text { Fourth..... }\end{array}$ & $\begin{array}{l}1,502-1,585 \\
1,635-1,735 \\
1,740-1,770 \\
1,800-1,830 \\
1,843-1,880 \\
1,940-1,955 \\
1,986-2,015\end{array}$ & $\begin{array}{l}\text { Water at } 1,508 \text { feet. } \\
\text { Oil at } 1,775-1,765 \text { feet. }\end{array}$ \\
\hline
\end{tabular}


Partial records of wells drilled for oil and gas-Continued

Pine Township, Allegheny County - Continued

\begin{tabular}{|c|c|c|c|c|c|c|}
\hline \multirow[b]{2}{*}{ Farm } & \multirow[b]{2}{*}{ No. } & \multirow[b]{2}{*}{ Owner of well } & \multirow{2}{*}{$\begin{array}{c}\text { Alti- } \\
\text { tude of } \\
\text { casing } \\
\text { head } \\
\text { above } \\
\text { sea level } \\
\text { (feet) }\end{array}$} & \multicolumn{2}{|c|}{ Oil and gas sands } & \multirow[b]{2}{*}{ Remarks } \\
\hline & & & & Name of sand & $\begin{array}{l}\text { Depth } \\
\text { (feet) }\end{array}$ & \\
\hline English & 1 & 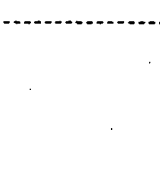 & & $\begin{array}{l}\text { Murrysville.-. } \\
\text { Hundred-foot. } \\
\text { Thirty-foot.... } \\
\text { Boulder. } \\
\text { Third } \\
\text { Fourth } \\
\text { Fifth } \\
\text { Speechloy. }\end{array}$ & $\begin{array}{l}1,530-1,654 \\
1,660-1,760 \\
1,776-1,808 \\
1,881-1,907 \\
1,920-1,946 \\
1,980-1,990 \\
2,040-2,050 \\
2,882-2,902\end{array}$ & $\begin{array}{l}\text { Gas at } 2,046 \text { feet. } \\
\text { Gas at } 2,885 \text { feet. }\end{array}$ \\
\hline
\end{tabular}

McCandless Township, Allegheny County

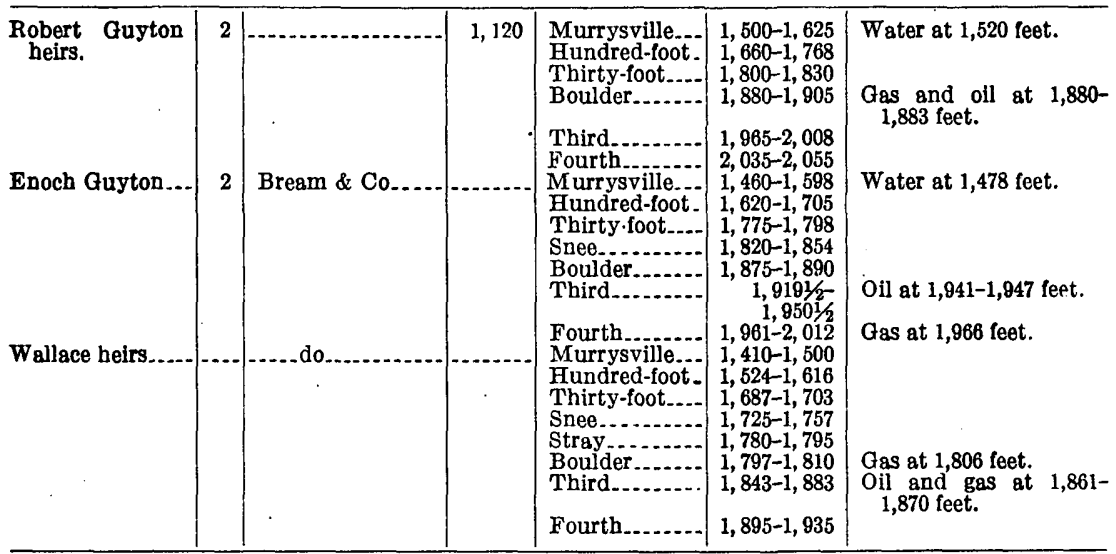

Hampton Township, Allegheny County

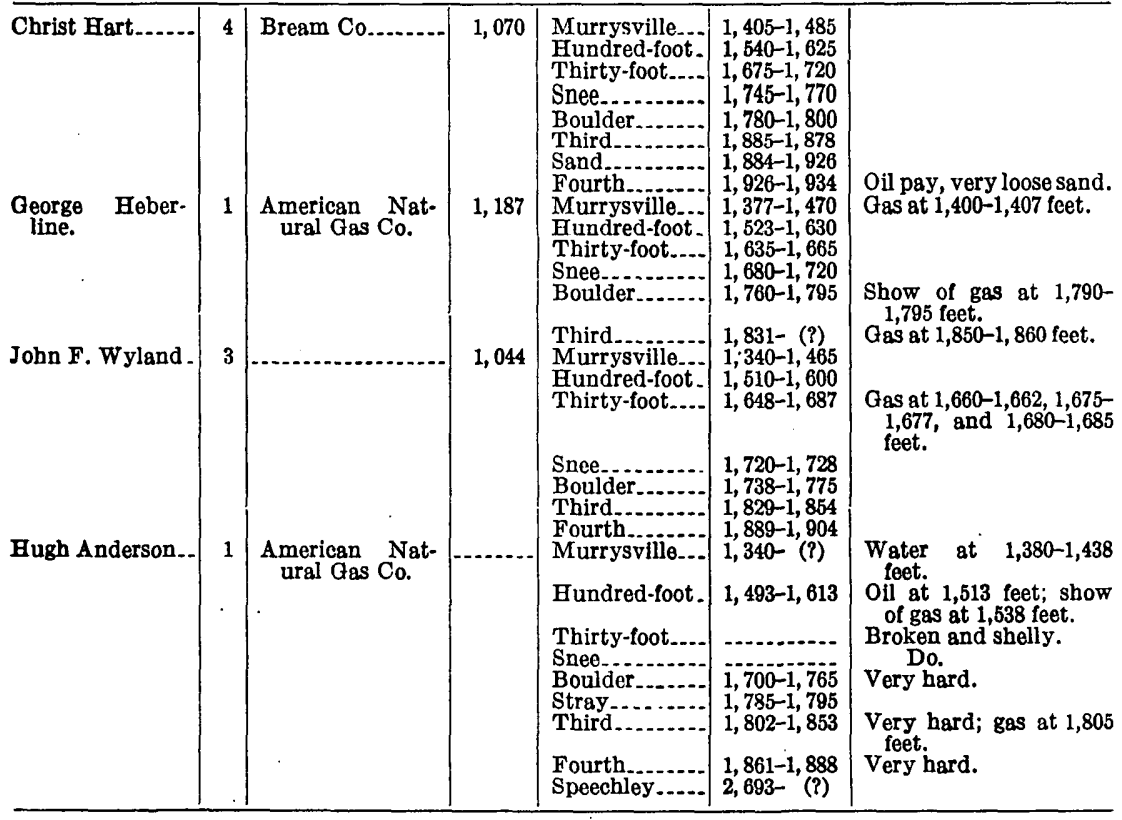


APPENDIX

Partial records of wells drilled for oil and gas-Continued

Indiana Township, Allegheny County॰

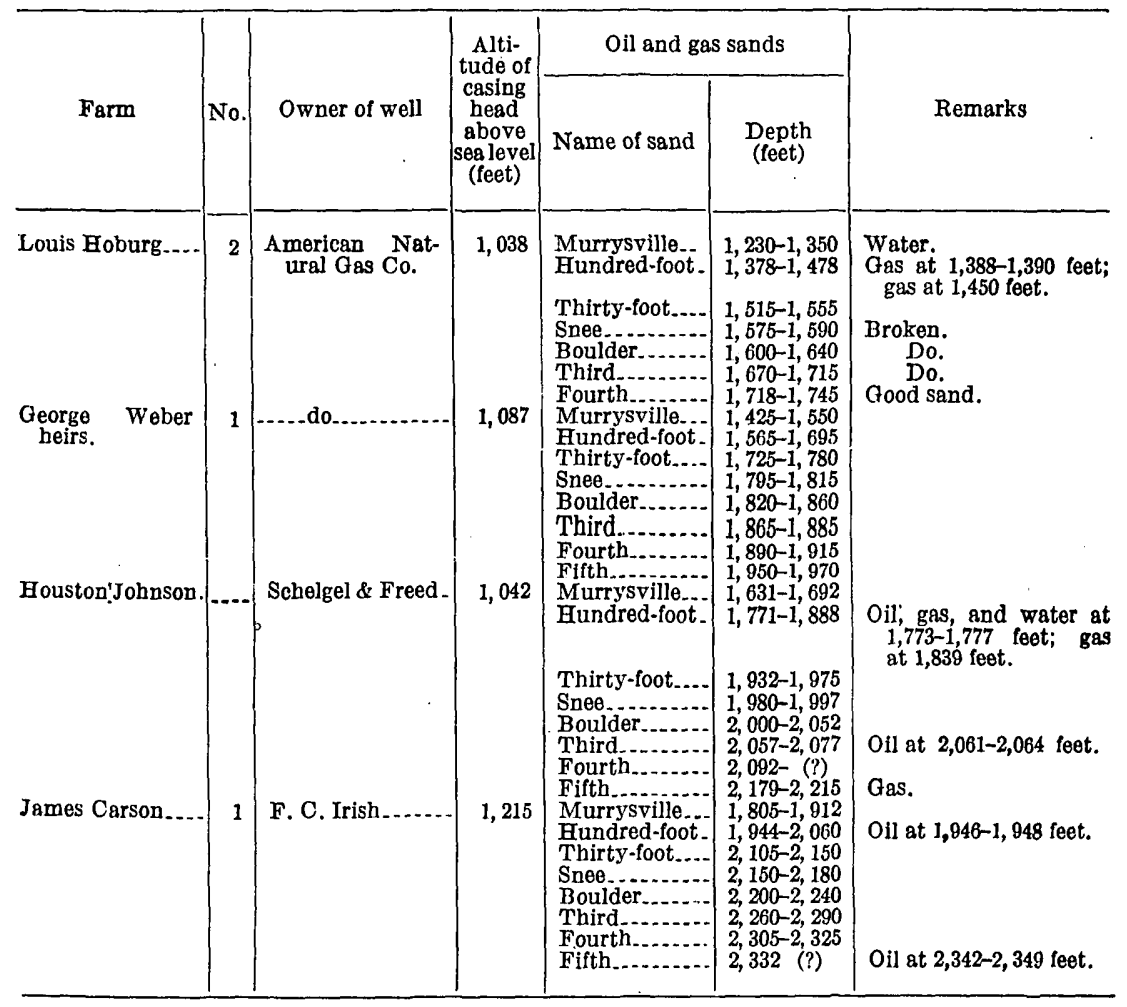

Harmar Township, Allegheny County

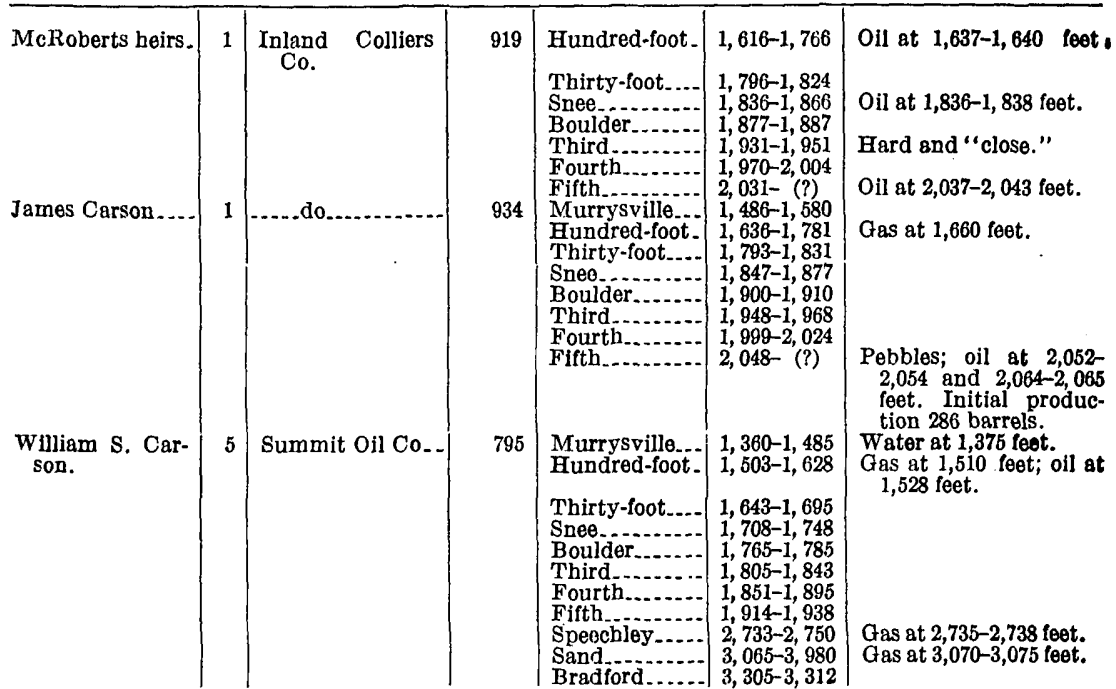

\footnotetext{
$\because$ For records of wells in Dorseyville field, see p. 64.
} 
Partial records of wells drilled for oil and gas-Continued

Harmar Township, Allegheny County-Continued

\begin{tabular}{|c|c|c|c|c|c|c|}
\hline \multirow[b]{2}{*}{ Farm } & \multirow[b]{2}{*}{ No. } & \multirow[b]{2}{*}{ Owner of well } & \multirow{2}{*}{$\begin{array}{c}\text { Alti- } \\
\text { tude of } \\
\text { casing } \\
\text { head } \\
\text { above } \\
\text { sea level } \\
\text { (feet) }\end{array}$} & \multicolumn{2}{|c|}{ Oil and gas sands } & \multirow[b]{2}{*}{ Remarks } \\
\hline & & & & Name of sand & $\begin{array}{l}\text { Depth } \\
\text { (feet) }\end{array}$ & \\
\hline J. J. Drunnel .... & 3 & $\begin{array}{l}\text { Chemical Oil \& } \\
\text { Gas Co. }\end{array}$ & 1,164 & $\begin{array}{l}\text { Murrysville..- } \\
\text { Hundred-foot.. } \\
\text { Thirty-foot... } \\
\text { Snee } \\
\text { Boulder... } \\
\text { Third } \\
\text { Fourth... } \\
\text { Fifth }\end{array}$ & $\begin{array}{l}1,740-1,855 \\
1,872-1,902 \\
\\
2,021-2,071 \\
2,080-2,112 \\
2,125-2,136 \\
2,171-2,186 \\
2,215-2,252 \\
2,274-2,290\end{array}$ & $\begin{array}{l}\text { Gas, oil, and water, } \\
1,895-1,898 \text { feet. } \\
\text { Gas at } 2,276-2,280 \text { feet. }\end{array}$ \\
\hline
\end{tabular}

Plum Township, Allegheny County

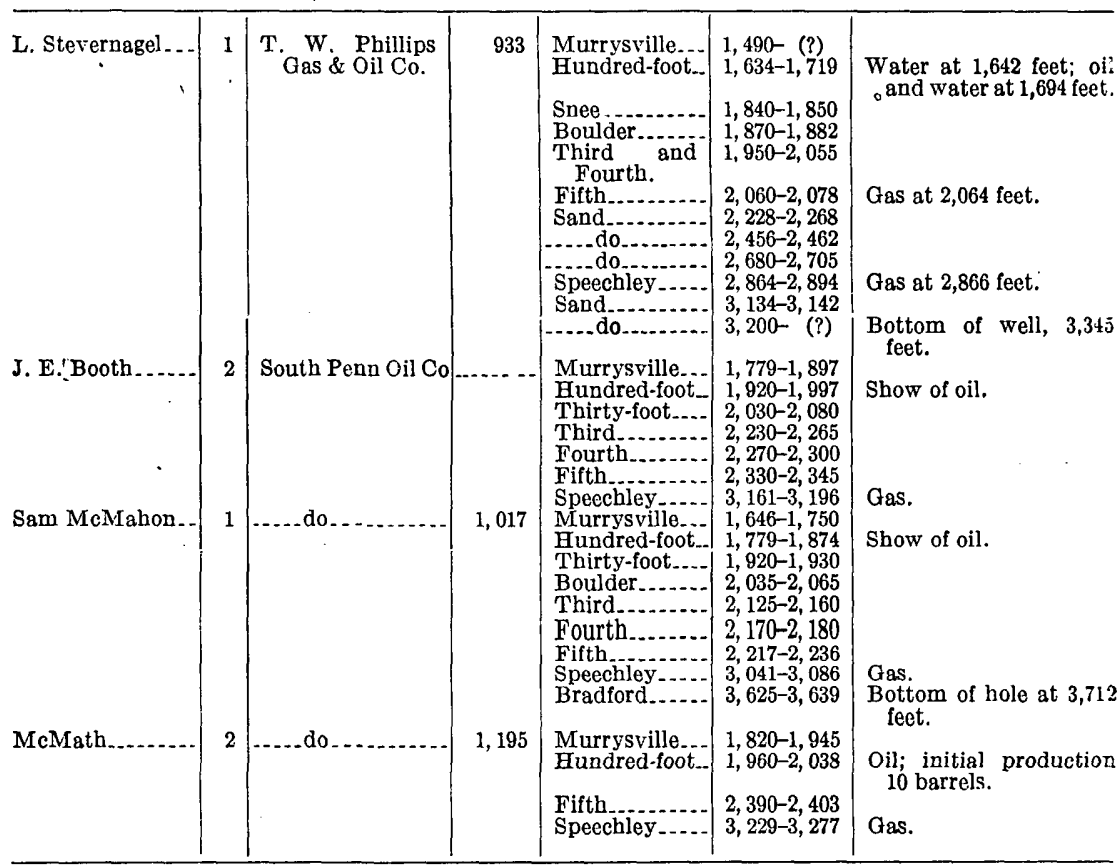

O'Hara Township, Allegheny Cou nty

\begin{tabular}{|c|c|c|c|c|c|c|}
\hline McRoberts...... & 1 & Chemical Oil Co. & 1,058 & 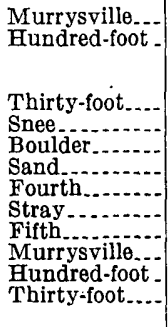 & $\begin{array}{l}1,640-1,740 \\
1,794-1,900 \\
\\
1,940-1,983 \\
1,996-2,016 \\
2,032-2,090 \\
2,104-2,147 \\
2,149-2,170 \\
2,175-2,185 \\
2,187-2,202 \\
1,635-1,735 \\
1,780-1,885 \\
1,958-1,996\end{array}$ & $\begin{array}{l}\text { Oil and water at } 1,79 \\
\text { feet; show of oil at } \\
1,831 \text { feet. } \\
\text { Oil at } 1,961-1,965 \text { feet } \\
\text { oil at } 1,968-1,974 \text { feet. }\end{array}$ \\
\hline
\end{tabular}


Partial records of wells drilled for oil and gas-Continued

Shaler Township, Allegheny County

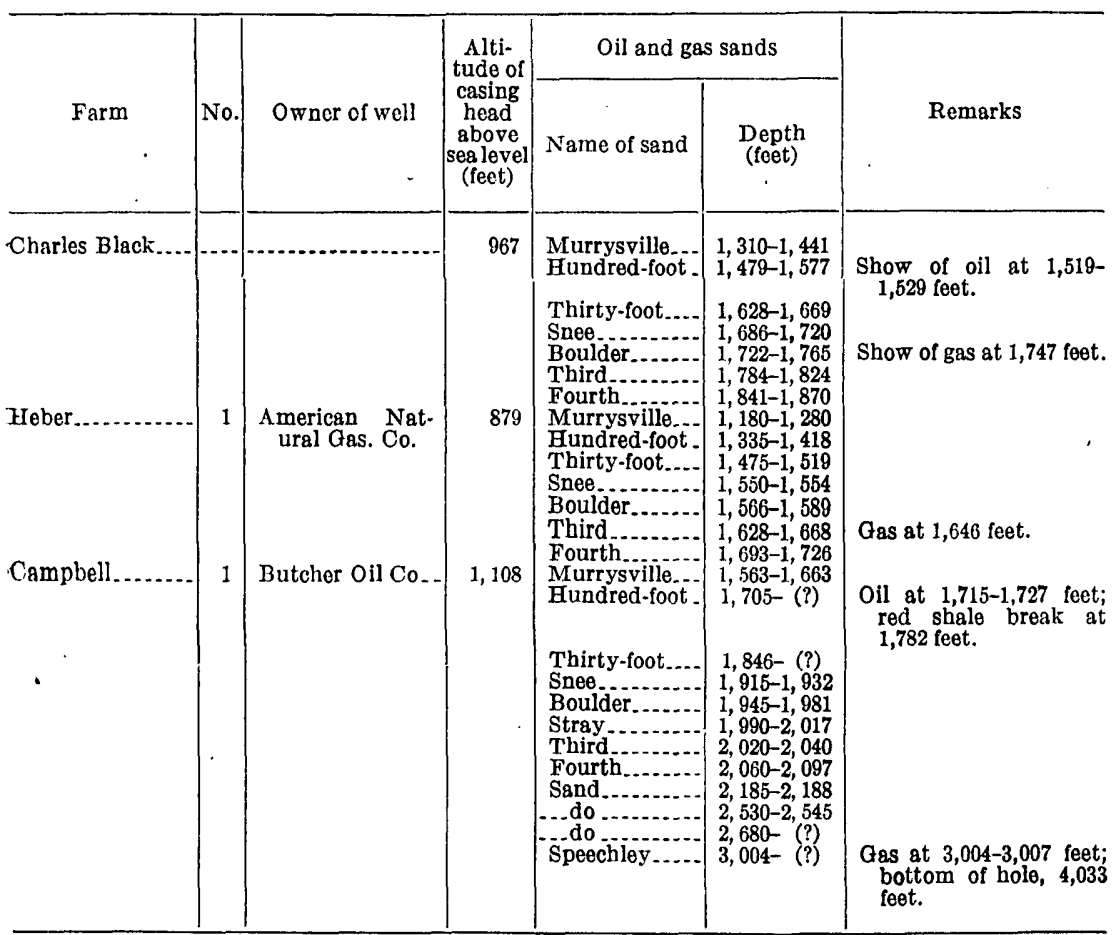

Ross Township, Allegheny County

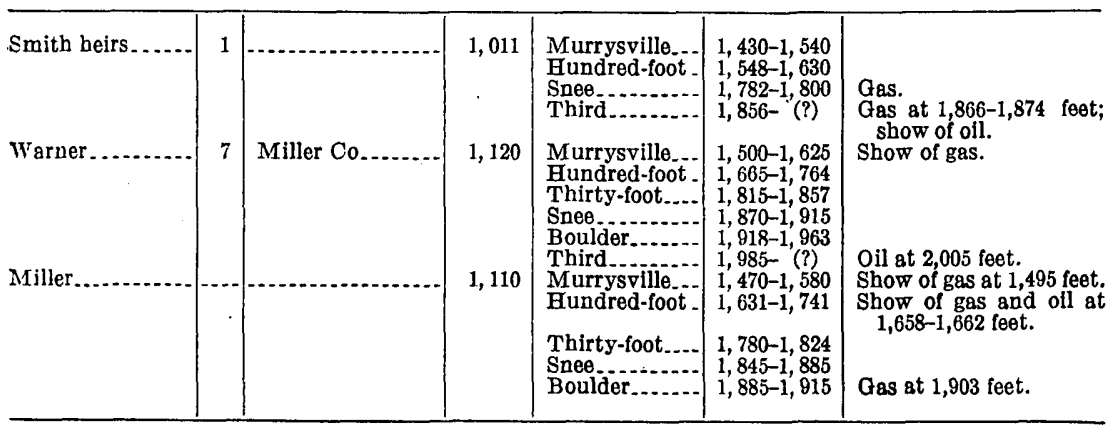





\section{INDEX}

A.

Abstract of report...

Page

(1) vIII

Acknowledgments for aid . ................. 1

Adams Township, records of wells in ........ 90

Allegheny formation, character and distribution of.

11-15

exposures of, map showing ............... pl. 1

occurrence of ........................... 10

sections of ................................ 14-15

subdivisions of . ...................... 10

Allegheny River, indications of former oxbow curve in

tributary streams of . . . . . .

Allegheny RIver Valley, evidences of glaciation in.

Upper Freeport coal in

Alluvium, deposits of

Ames limestone, character and distribution of.

fossils and stratigraphic position of......

Amity anticline, Bull Creek and Milltown gas fields on.

general features of

Upper Freeport cool in

"Anthraxylon." See "Bright coal."

A ppalachian Highlands, location of

position of New Kensington quadrangle in ...............................

Appalachian region; northern, events during Tertiary period in.

northern, extent of first ice invasion in...

structure of ................. $49, \mathrm{pl} .3$

"Attritus." See "Dull coal."

B

Bailey Run, Upper Freeport coal near.......

Bakerstown coal, character and distribution of.............................. 21, 40

sections of

41

type locality of.......................... 21, 40

Bakerstown field, gas and oil in ............. 61-62

general features of ........................ 60-61

Bakerstown station, faults near.............. 30-31

Benjamin mine, measurements of Upper Freeport coal in ...................

Berea quadrangle, Ohio. See Cleveland, Berea, and Euclid quadrangles: -

Berry mine, measurements of Upper Freeport coal in.

Bessemer mine, measurements of Upper Freeport coal in

Birmingbam shale, character and strati.

graphic position of ................ 23

85

79

85

85

Booth \& Flinn well No. 3, record of . ....... 75-78

Bradford field, discovery of oil in.
33
Bradford sand, prospects for future production from........................ 71-73

Bradys Bend syncline, general features of.... 30

"Bright coal," origin of...................... 36

Brine wells, oil from, discovery of ............ 47-48

oil from, production of ................... 55

Brush Creek limestone, character and distribution of...................... 17-18

fossils of ............................... 19

type locality of ........................... 17

Buchter farm well No. 1, analysis of oil from. 69

Buffialo sandstone, character and distribution of

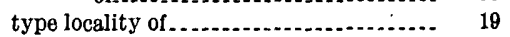

Buffalo Township, records of wells in........ 91

Bull Creek, Upper Freeport coal near ....... 33

Bull Creek-Tarentum gas field, general features and development of.. 56-57, 58-59

Butler County gas sand. See Murrysville sand.

Butler sandstone, character and occurrence of. $\quad 15$

$$
\text { C }
$$

Cambridge ("Pine Creek") limestone, charac-

Can

3

fossils of

Cannel coal, origin of ........................ 36

Carboniferous system, character, distribution, and subdivisions of......... 11-25

Catskill formation, occurrence of.............. 9

Cleveland, Berea, and Euclid quadrangles, Ohio, generalized sections of rocks in

"Clinton" sand, occurrence of.............. 8-9

Clinton Township, records of wells in....... 90-91

Coal, production of, by mines and companies, table showing................... 46

Coal beds, development of ...................... 32-33

dip of, structure contours showing ....... pl. 2

(in pocket)

names of................................. 31

stratigraphic position of................ pls, 4, 5

See also Bakerstown coal; Pittsburgh coal; Upper Freeport coal.

Coal Hollow, section of Upper Freeport coal in . . .

Cosl mines, names and locations of, map showing -.............. pl. 2 (in pocket)

Columbus quadrangle, Ohio, generalized sections of rocks in................. 79

Conemaugh formation, character, distribu. tion, and subdivisions of.......... 15-16

Cox farm, analysis of oil from................ 69

Creighton, use of natural gas in industry at.. 58

Creighton mine, measurements of Upper Freeport coal in. 
'Crinoidal" limestone. See Ames limestone. Cunningham, Upper Freeport coal near, sections of.

\section{D}

Dawson country bank, section of Upper Freeport coal at.

Deer Township. See East Deer Township; West Deer Township.

Dorseyville oil field, general features and development of

sections of oil-bearing sands in .......... $86-89$

Drainage, features of

"Dull coal," origin of

Duquesno coal, char stratigraphic position of

\section{$\mathbf{E}$}

East Deer Township, records of wells in..... 91-92 section of Allegheny formation above....

Elfinwild, section of Allegheny formation at.

Elk Lick coal. See Duquesne coal.

Euclid quadrangle, Ohio. See Cleveland Berea, and Euclid quadrangles.

Evergreen oil field, general character of ...... $\log$ of well in

Faults

Fawn Township, records of wells in section of Allegheny formation in.......

Fifth sand, analysis of oil from

Folds, relation of, in surface and deep-lying rocks...................................

Foraminifera, in Brush Creek limestone.....

Fossils, in Ames limestone

in Brush Creek limestone...........

Fourth sand, analysis of oil from character of

Francis mine, measurements of Upper Freeport coal in

Francke farm, analysis of oil from. ..........

Freeport coal. See Lower Freeport coal; Upper Freeport coal.

\section{G}

Gas. See Appalachian region, northern; Natural gas; Oil and gas.

Gas sands in northern Appalachian region, map showing

table showing

See also Oil and gas sands.

Geary well, record of

Geologic maps of the New Kensington quadrangle.............. pls. 1, 2 (in pocket)

Glacial history in northwestern Pennsylvania, brief outline of.

Glade Run, Upper Freeport coal near

Glade Run oil field, general features of ........

Glade Run Valley, Upper Freeport coal near, exposure of

Glenshaw, Upper Freeport coal near, section of.

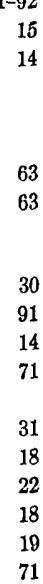

Page

Glenshaw oil field, general character of ...... 65

"Green fossiliferous" limestone. See Ames limestone.

\section{H}

Hampton Township, records of wells in.....

Harlem coal, stratigraphic position of ......... Harmar mine, measurements of Upper Freeport coal in

Harmar Township, records of wells in ....... 95-96

Hass wells Nos. 3 and 5, sections of oil-bearing sands on.

Hodil heirs wells Nos. 3, 4, and 6, sections of oil-bearing sands in............... 86-87

Hoeveler well No. 1, $\log$ of................... 64

Hoeveler well No. 3, sections of oil-bearing sands in

Hollidaysburg and Huntingdon quadrangles, $\mathrm{Pa}$., generalized sections of rocks in .............................. 82-83

Hundred-foot sand, analyses of oil from.....- $\quad 69$ production of oil and gas from ............ 59-60 sections of, in Dorseyville oil field ....... 86-89 thickness of................................ 53 use of, as datum plane................... 53

Huntingdon quadrangle, $\mathrm{Pa}$. See Hollidaysburg and Huntingdon quadrangles.

I

Illinoian (?) glacial deposits, character, distribution and thickness of ....... 26-27

Indiana Township, records of wells in....... 95

section of Pittsburgh coal in.............. $\quad 25$

Indianola mine, measurements of Upper Freeport coal in

Industries in the New Kensington quadrangle

\section{K}

Kellersburg anticline, general features of..... 29-30

Glenshaw oil field on:.................... 65

Upper Freeport coal in .................. 30

Wildwood oil field on ..................... 63

Kittanning coals, extent of investigations of - 10-11

\section{$\mathrm{L}$}

Lardintown, discovery of gas at............. gas well near.

section of Upper Freeport coal near...... Lardintown gas area. See Saxon-Lardintown gas area.

Logans Ferry, Pittsburgh coal at.............

51

56

37

M

Mahoning coal, character of ..................

Mahoning sandstone, character and stratigraphic position of ................ 16-17 Mar mine, section of Upper Freeport coal in. Marshall farm, well on, log of

well on, initial production of McCandless Township, records of wells in... McDowell Run, Upper Freeport coal on, section of 
Page

McMahon farm, log of well on................

McMurray syncline, general features of......

Middlesex Township, records of wells in.....

Millerstown oil field, general features of..... 65-66

Milltown, gas wells near.

Monongahela formation, character and distribution of..................... 23-25

thickness of.

Morgantown sandstone, character and distribution of.

Mount Royal, Upper Freeport coal at, section of.

Murrysville sand, gas wells in................ thickness of

\section{$\mathrm{N}$}

Natrona, use of natural gas in industry at...

Natural gas, early use in industry of......... first successful piping of

Natural gas in New Kensington quadrangle, analyses of ........................... discovery of. trata yielding.

table showing.

See also Appalachian region, northern Oil and gas; Oil and gas sands.

New Field mine No. 1, measurements of Upper Freeport coal in.

Niagara Falls quadrangle, N. Y., generalized sections of rocks in

Nicholas farm, log of well on .

Nineveh syncline, relation of McMurray syncline to

\section{0}

Oakmont mine, measurements of Upper Freeport coal in

O'Hara Township, records of wells in

Oil, annual output of in Pennsylvania $-a^{-}$

derivation of

discovery of, in New Kensington quadrangle...

See also Oil in New Kensington quadrangle.

Oil and gas, principal areas in New Kensington quadrangle producing....... 57-67

Oil and gas sands encountered in drilling.... pl. 8

(in pocket)

general features of

$50,52-55$

stratigraphic position of . .............. 9, 52-53

structural features of

table showing.

50

Oil in New Kensington quadrangle, analyses of.

character of 69-71

prospects of future production of ........ $71-73$ Ostracodes in Brush Creek limestone......... 18

\section{P}

Pennsylvania, southwestern, structure contour map of ..................... pl. 7

Pennsylvanian series, character, distribution, and subdivisions of .............. 11-25

Peterson mine, measurements of Upper Freeport coal in.
Petroleum. See Oil.

"Pine Creek" limestone. See Cambridge limestone.

Pine Township, records of wells in.......... 93-94

Pittsburgh coal, character of.................. 24 distribution of........................... 41 map showing .................. pl. 2 (in pocket) sections of .................................. 24-25

thickness of............................... 24, 41

Pittsburgh-Huntington Basin, geologic structure of ......................... 4-5 geologic structure of, map showing........ pl. 3

location of ................................ 3-4 marginal areas of, generalized sections of rocks in.. $79-83$

position of New Kensington quadrangle in

"Pittsburgh Reds," character and stratigraphic position of

Pleistocene and Recent series, exposed deposits of, character, distribution, and subdivisions of .............. 25-28

Plum Creek Valley, gas wells in.............. 59

Plum Township, depth, thickness, and succession of oil sands in............ 60

records of wells in......................... 96

section of Pittsburgh coal in ............ 24

Pocono formation, occurrence of............. 9

Porosity of sands, table showing............. 5

Porter Coal Co., mine of, Upper Freeport coal in, section of.

10 .

\section{Q}

Quaternary system, exposed rocks of, character, distribution, and subdivisions of.

\section{$\mathbf{R}$}

Recent alluvial deposits, character of .........

Recent series. See Pleistocene and Recent series.

Reith mine, section of Upper Freeport coal in. $\quad 36$

Relief of the New Kensington quadrangle ... 5

Rich Hill, Pittsburgh coal in................ 29,41

Pittsburgh coal in, section of ............ 25

Richland Township, faults in................ 30

faults in, character of rocks exposed in... $\quad 31$

records of wells in....................... 93

Robinson farm, analysis of oil from .......... 70

Robinson wells Nos. 1-6, sections of Hundredfoot and Thirty-foot sands in .... 87-89

Ross Township, records of wells in........... $\quad 97$

$$
\mathrm{S}
$$

Saltsburg sandstone, character, stratigraphic position, and type locality of....

Salt wells. See Brine wells.

Saxon-Lardintown gas area, development and production of...................... 57

$\log$ of well in . ......................... 58

map showing................... pl. 2 (in pocket)

sands of, character of .................. 57 
Settlemeyer country bank, section of Upper Freeport coal at'.

Shaler Township, records of wells in.......... Somerset and Windber quadrangles, $\mathrm{Pa}$., generalized sections of rocks in .......

Speechley sands, prospects of future production from $58,71-73$

Springdale, glacial benches near........ 26-27, pl. 1 Springdale mine, measurements of Upper Freeport coal in ..................

Staley well, $\log$ of

Structure of $\mathrm{New}$ Kensingtong 2 (in pocket)

relation of, to that in other parts of southwestern Pennsylvania.

Sun mine, section of Upper Freeport coal in.. Superior mine, measurements of Upper Freeport coal in.

\section{$\mathbf{T}$}

Tarentum, brine wells near, oil from ..... 47-48, 55 gas area near, opening of. $56-57$

Upper Freeport coal near $12-13,33,38$

section of

use of natural gas in industry near.......

See also Bull Creek-Tarentum gas field.

Tertiary period, events in northern Appalachian region during

Thick Upper Freeport coal, area underlain by, map of.

composition of.

method of mining

mines operating on, depth of coal beneath surface in............... pl. 2 (in pocket)

list of.

location of................. pl. 2 (in pocket) stratigraphic relations of. See also Upper Freeport coal

Third sand, varying porosity of water in. rty-foot sand, analysis of oil from sections of in Dorseyville oil field

Thirty-foot sand in Dorseyville oil field, $\log$ of well showing details of

Thompson farm, analysis of oil from.

64

71

\section{U}

Page

Upper Freeport coal, absence of, in parts of New Kensington quadrangle .... 12-14 beds below, character of .................. 41-42 character of ............................... 14

depth of horizon of, method of determining.

estimate of reserves of ................... 46

exposures of, location of ................. 33-34

oil from, possibility of obtaining......... 47 sections of ................. 13-14, 35, 36-39, 83-85 stratigraphic relation of, to Lower Freeport coal

thickness of $11-12,34,83-85$

type locality of 11

See also Thick Upper Freeport coal.

Upper Freeport coal in-

Amity anticline.

Kellersburg anticline.................... 29-30

McMurray syncline....................... $\quad 2 \theta$

Upper Freeport limestone, character and stratigraphic position of ......... 14

\section{V}

Valley Camp, glacial benches near 26, pl. 1

Valley Camp mine, sections of Upper Freeport coal at..................... 13

Vanport limestone, occurrence of

\section{W}

Warner well No. $7, \log$ of .................... 63

Warren quadrangle, $\mathrm{Pa} . \mathrm{N}$. Y., generalized sections of rocks in . .............. 81

Wells, oil and gas, records of................ 90-97

West Deer Township, records of wells in . ... 92-93

Wildwood, Upper Freeport coal near......... $\quad 39$

Wildwood oil field, general features of ........ 62-63

structural position of ...................... 63

Wilson Run, Upper Freeport coal near...... 33

Windber quadrangle, $\mathrm{Pa}$. See Somerset and Windber quadrangles.

Wisconsin glacial deposits, evidences of....... 